DOE/EIA-0202(93)

Distribution Category UC-950

\title{
Short-Term Energy Outlook Annual Supplement 1993
}

August 1993

\section{Energy Information Administration}

Office of Energy Markets and End Use

U.S. Department of Energy

Washington, DC 20585

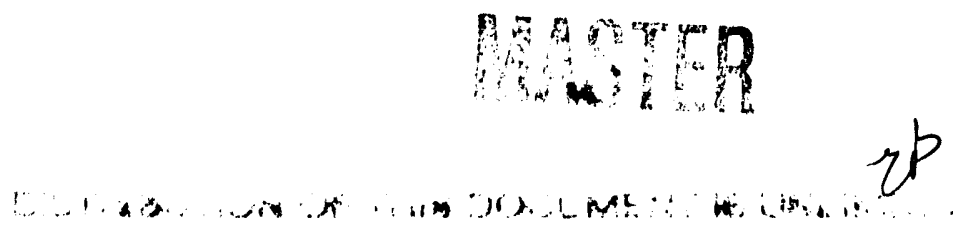

This report was prepared by the Energy Information Administration, the independent statistical and analytical agency within the Department of Energy. The information contained herein should not be construed as advocating or reflecting any policy position of the Department of Energy or any other organization. 


\section{Contacts}

The Short-Term Energy Outlook Annual Supplement is prepared by the Energy Information Administration (EIA), Office of Energy Markets and End Use (EMEU). General questions concerning the content of the report may be directed to W. Calvin Kilgore (202/586-1617), Director of EMEU; Arthur T. Andersen (202/586-1441), Director of Energy Markets and Contingency Information Division; or Derriel B. Cato (202/586-6574), Chief of the Short-Term Forecasting and Contingency Branch.

Detailed questions may be referred to David Costello (202/586-1468) and Neil Gamson (202/586-2418), or to the following authors, who can be reached at the Energy Markets and Contingency Information Division (202/586-1441).

Demand, Supply, and Price Outlook for Low Sulfur Diesel Comparison of EIA and Other Forecasts for 1993 and 1994 Forecast Evaluation

Forecast Error Benchmarks for the Short-Term Integrated Forecasting System
Tancred Lidderdale

Michael Morris

Neil Gamson

David Costello 


\section{Contents}

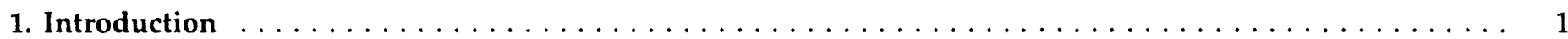

2. Demand, Supply, and Price Outlook for Low Sulfur Diesel $\ldots \ldots \ldots \ldots \ldots \ldots \ldots \ldots \ldots \ldots \ldots$

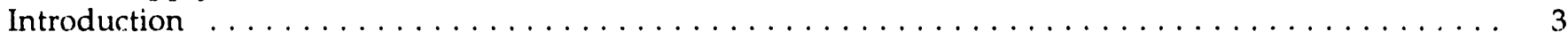

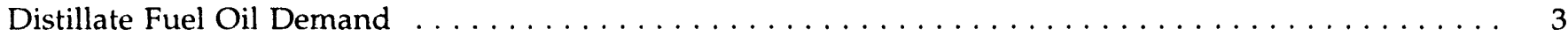

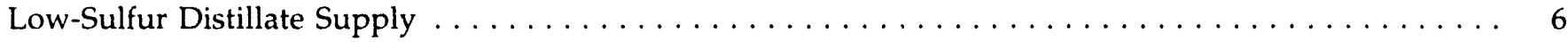

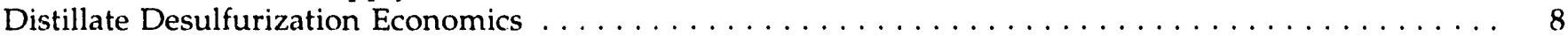

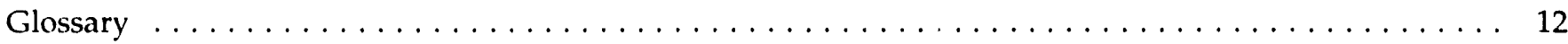

3. Comparison of EIA and Other Forecasts for 1993 and $1994 \ldots \ldots \ldots \ldots \ldots \ldots \ldots \ldots \ldots \ldots$

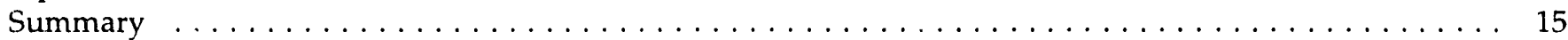

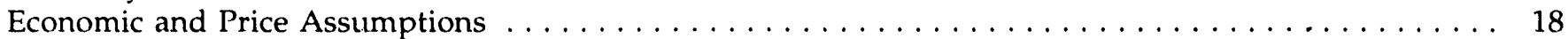

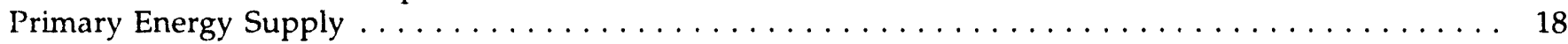

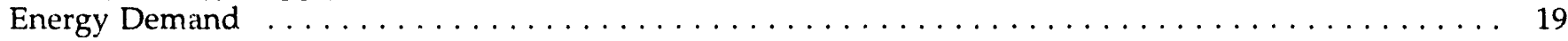

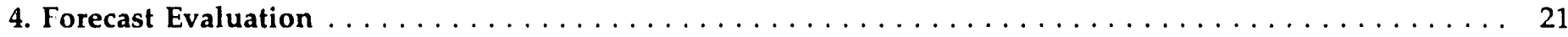

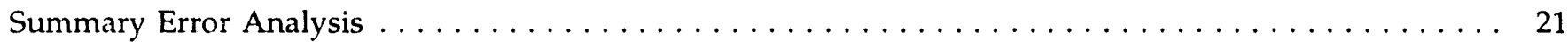

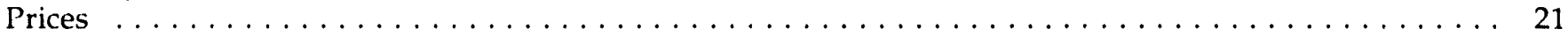

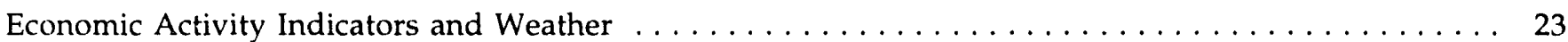

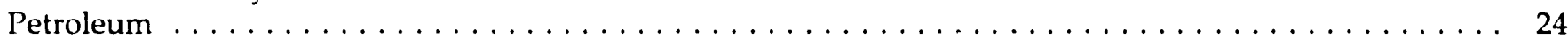

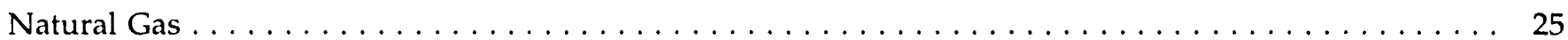

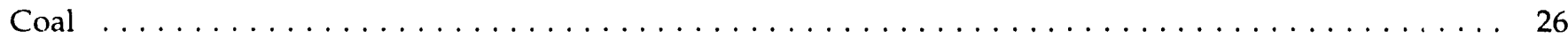

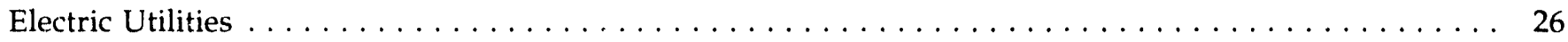

5. Forecast Error Benchmarks for the Short-Term Integrated Forecasting System $\ldots \ldots \ldots \ldots \ldots$

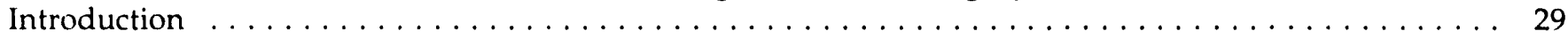

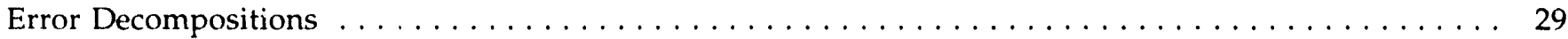

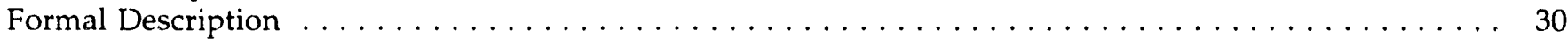

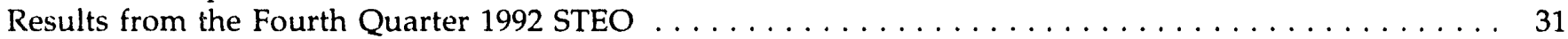

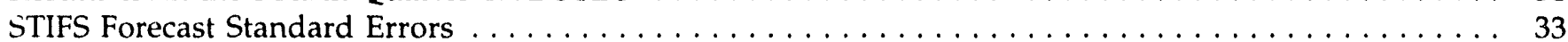

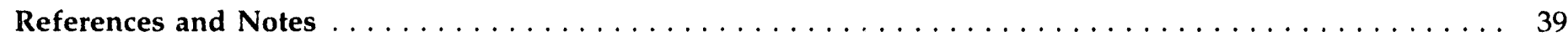

\section{Appendices}

A. Detailed Forecast Error Tables $\ldots \ldots \ldots \ldots \ldots \ldots \ldots \ldots \ldots \ldots \ldots \ldots \ldots \ldots \ldots \ldots \ldots \ldots \ldots$

B. Placing Uncertainty Estimates on Key Exogenous Inputs to STIFS $\ldots \ldots \ldots \ldots \ldots \ldots \ldots$ 


\section{Tables}

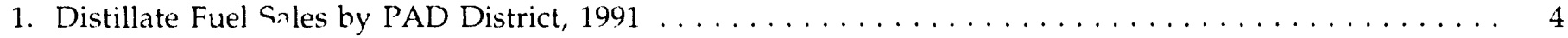

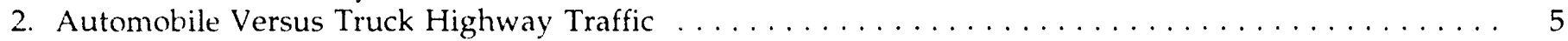

3. Transportation Sector Distillate Fuel Demand Short-Term Forecast $\ldots \ldots \ldots \ldots \ldots \ldots \ldots \ldots \ldots \ldots \ldots$

4. U.S. Distillate Hydrotreating Capacity, January $1,1992 \ldots \ldots \ldots \ldots \ldots \ldots \ldots \ldots \ldots \ldots \ldots \ldots \ldots$

5. Foreign Distillate Hydrotreating Capacity, January 1, $1992 \ldots \ldots \ldots \ldots \ldots \ldots \ldots \ldots \ldots \ldots \ldots \ldots \ldots$

6. NPRA Survey Estimates of Low-Sulfur Distillate Variable Production Cost $\ldots \ldots \ldots \ldots \ldots \ldots \ldots \ldots$

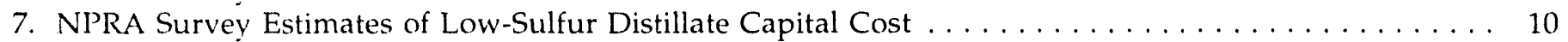

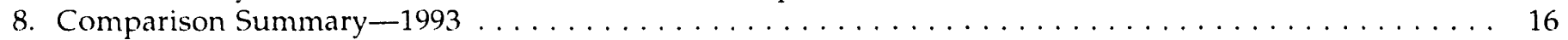

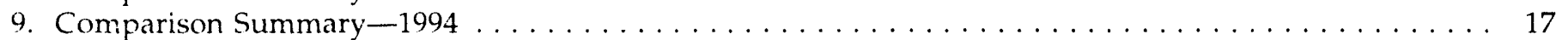

10. Summary of Absolute Errors, 1993 Annual Supplement Compared to 1992 Annual Supplement . . . . . . . 22

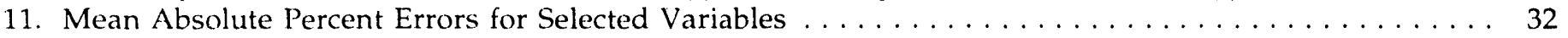

12. Relative Forecast Standard Errors for Selected STIFS Variables $\ldots \ldots \ldots \ldots \ldots \ldots \ldots \ldots \ldots \ldots \ldots . \ldots$

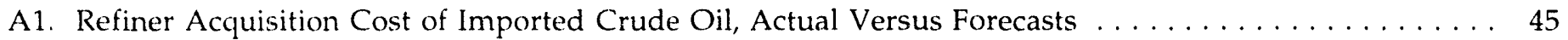

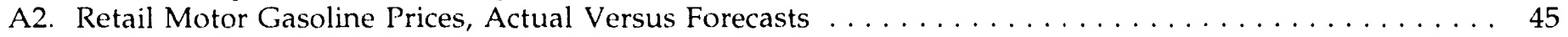

A3. Residential Heating Oil Prices, Actual Versus Forecasts $\ldots \ldots \ldots \ldots \ldots \ldots \ldots \ldots \ldots \ldots \ldots \ldots \ldots$

A4. Residual Fuel Oil Prices, Actual Versus Forecasts $\ldots \ldots \ldots \ldots \ldots \ldots \ldots \ldots \ldots \ldots \ldots \ldots$

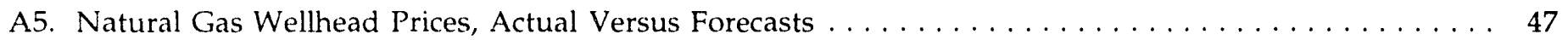

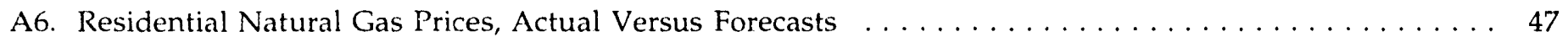

A7. Residential Electricity Prices, Actual Versus Forecasts $\ldots \ldots \ldots \ldots \ldots \ldots \ldots \ldots \ldots \ldots \ldots \ldots \ldots$

A8. Electric Utility Coal Prices, Actual Versus Forecasts $\ldots \ldots \ldots \ldots \ldots \ldots \ldots \ldots \ldots \ldots \ldots \ldots$

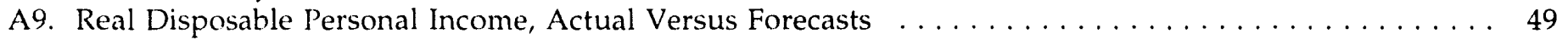

A10. Industrial Production Index for Manufacturing, Actual Versus Forecasts . . . . . . . . . . . . . 49

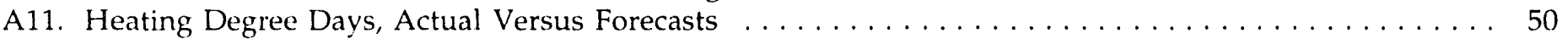

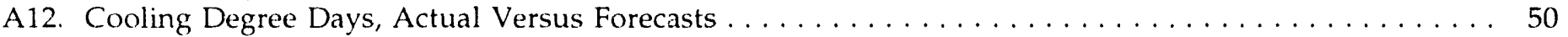

A13. Total Petroleum Demand (Product Supplied), Actual Versus Forecasts $\ldots \ldots \ldots \ldots \ldots \ldots \ldots \ldots$

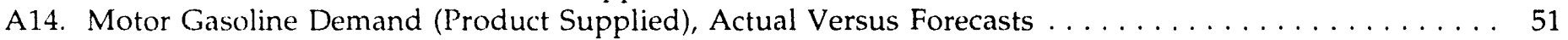

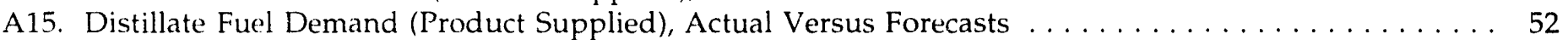

A16. Residual Fuel Oil Demand (Product Supplied), Actual Versus Forecasts $\ldots \ldots \ldots \ldots \ldots \ldots \ldots \ldots$

A17. Jet Fuel Demand (Product Supplied), Actual Versus Forecasts $\ldots \ldots \ldots \ldots \ldots \ldots \ldots \ldots \ldots \ldots \ldots$

A18. Other Petroleum Products Supplied, Actual Versus Forecasts $\ldots \ldots \ldots \ldots \ldots \ldots \ldots \ldots \ldots$

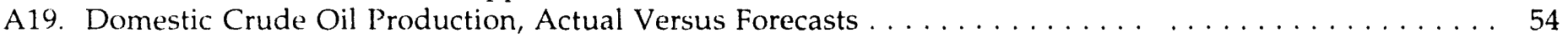

A20. Alaskan Crude Oil Production, Actual Versus Forecasts $\ldots \ldots \ldots \ldots \ldots \ldots \ldots \ldots \ldots \ldots \ldots \ldots$

A21. Lower 48 Crude Oil Production, Actual Versus Forecasts $\ldots \ldots \ldots \ldots \ldots \ldots \ldots \ldots \ldots \ldots \ldots \ldots$

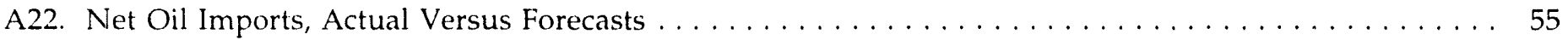

A23. Total Petroleum Stocks, Actual Versus Forecasts $\ldots \ldots \ldots \ldots \ldots \ldots \ldots \ldots \ldots \ldots \ldots \ldots \ldots \ldots \ldots$

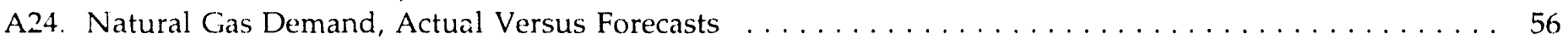

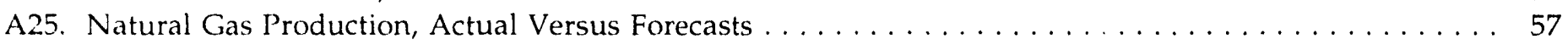

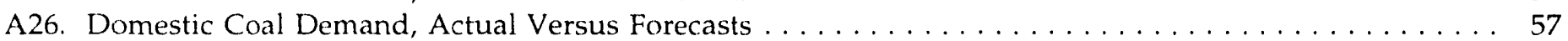

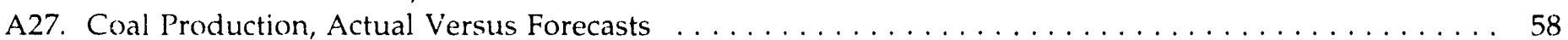

A28. Total Electricity Sales, Actual Versus Forecasts $\ldots \ldots \ldots \ldots \ldots \ldots \ldots \ldots \ldots \ldots \ldots \ldots$

A29. Residential Electricity Sales, Actual Versus Forecasts $\ldots \ldots \ldots \ldots \ldots \ldots \ldots \ldots \ldots \ldots \ldots \ldots$

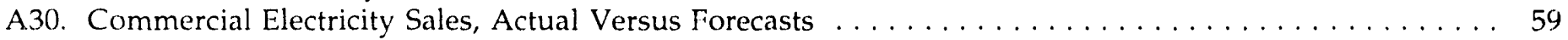

A31. Industrial Electricity Sales, Actual Versus Forecasts $\ldots \ldots \ldots \ldots \ldots \ldots \ldots \ldots \ldots \ldots \ldots \ldots \ldots \ldots \ldots$

A32. Electricity Generation from Coal, Actual Versus Forecasts $\ldots \ldots \ldots \ldots \ldots \ldots \ldots \ldots \ldots \ldots \ldots \ldots$

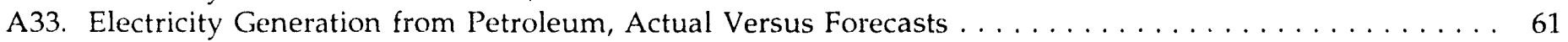

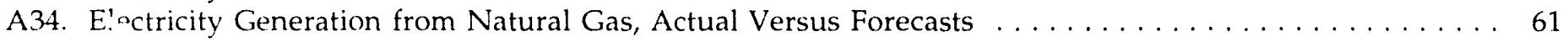

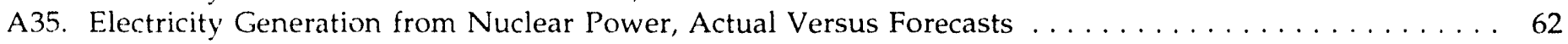

A36. Electricity Generation from Hydroelectric Power, Actual Versus Forecasts . . . . . . . . . . . . 62

B1. Key Exogenous Variables from STIFS Used in Stochastic Simulation $\ldots \ldots \ldots \ldots \ldots \ldots \ldots \ldots \ldots .64$

B2. Estimation Results for STIFS Exogenous Input Variables $\ldots \ldots \ldots \ldots \ldots \ldots \ldots \ldots \ldots \ldots \ldots \ldots$ 


\section{Figures}

1. On-Highway Diesel and Other Distillate Sales $\ldots \ldots \ldots \ldots \ldots \ldots$

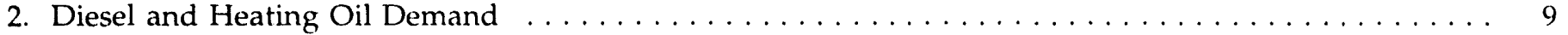

3. Forecast Errors for Imported Crude Oil Price . . . . . . . . . . . . . . . . . . . . . 33

4. Approximate 95-Percent Confidence Ranges for Selected Variables, 2Q/93 STEO . . . . . . . . . . . 37

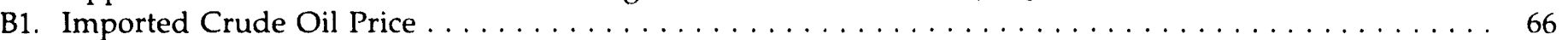

B2. Refinery Output Measures $\ldots \ldots \ldots \ldots \ldots$ 


\section{Introduction}

The Short-Term Energy Outlook Annual Supplement (Supplement) is published once a year as a complement to the Short-Term Energy Outlook (Outlook), Quarterly Projections. The purpose of the Supplement is to review the accuracy of the forecasts published in the Outlook, make comparisons with other independent energy forecasts, and examine current energy topics that affect the forecasts. A brief description of the content of each chapter follows below:

Chapter 2 presents an analysis of likely effects of the Clean Air Act Amendments of 1990 as they impact low sulfur diese! fuel. The Amendments require that refiners reduce the sulfur content of on-highway diesel fuel from current levels of 0.30 percent by weight to a maximum of 0.05 percent by weight starting on October 1,1993 . This chapter $\mathrm{v}$ ill analyze the effects that this regulation will have $c a$ demand, supply, and price in not only the diesel market, but also on the broader distillate fuel oil market.

Chapter 3 compares the Energy Information Administration's base or "mid" case energy projections for 1993 and 1994 as published in the first quarter 1993 Outlook with recent projections made by four other major forecasting groups. The chapter focuses on macroeconomic assumptions, primary energy demand, and primary energy supply, showing the differences and similarities in the five forecasts. Although there are more similarities than differences, the EIA forecasts tended be on the high side compared to the other forecasts for economic growth and energy demand.

Chapter 4 evaluates the overall accuracy of the shortterm energy forecasts published in the third quarter 1990 through the fourth quarter 1992 Outlooks. The energy forecasts evaluated for petroleum include: prices, demand, production, imports, and stocks. Forecasts for demand and production of natural gas and coal are aiso evaluated, as well as electricity sales and generation forecasts. The period of this evaluation is the third quarter 1991 through the end of 1992. This period covers a relatively stable period for world oil prices, but at the same time large fluctuations for natural gas wellhead prices.

Chapter 5 provides an error analysis for the major variables of the Short-Term Integrated Forecasting System (STIFS) model by simulating the fourth quarter 1992 Short-Term Integrated Forecasting System model through the first quarter of the 1993, using historical exogenous data through March 1993. This exercise resulted in separating that portion of the forecast error which was due to incorrect input assumptions and that portion of the forecast error which was due to model errors. Furthermore, a section of this chapter provides forecast standard errors for the major variables in STIFS. 


\section{Demand, Supply, and Price Outlook for Low-Sulfur Diesel Fuel}

\section{Introduction}

To help ensure that sulfates in engine exhaust do not prevent manufacturers of heavy-duty diesel engines from meeting new particulate emissions standards for 1994 and later model years, ${ }^{1}$ the Clean Air Act Amendments of 1990 (CAAA90) require refiners to reduce the sulfur content of on-highway diesel fuel from current average levels of 0.30 percent by weight to no more than 0.05 percent by weight. The new standard, which goes into effect October 1, 1993, also requires that on-highway diesel fuel have a minimum cetane index of 40 or a maximum aromatic content of 35 percent by volume. ${ }^{2}$ This provision is designed to prevent any future rises in aromatics levels. ${ }^{3}$ Since the direct measurement of aromatics is complex, a minimum cetane index of 40 is specified as a surrogate for capping aromatics. ${ }^{4}$ Except for California refineries, the level of aromatics does not appear to be a critical issue.
Home heating oil, a distillate product similar to diesel fuel, is not required to meet the new specifications. Off-highway diesel fuel and heating oil not meeting the new standards must be dyed in order to distinguish them from on-highway diesel fuel. The new diesel fuel standard applies Nationwide and affects about 46 percent of the total domestic demand for distillate fuel oil (or, about 8.2 percent of total U.S. petroleum product demand). ${ }^{5}$

Refiners will incur higher operating and capital costs in adapting to the new demand for low-sulfur diesel fuel. These increases will likely yield a price premium of 3 cents to 4 cents per gallon over heating oil and other high-sulfur distillate fuels. In California, the price premium will probably be higher because of a more restrictive aromatics specification, although no projection is attempted here. ${ }^{6}$

This chapter analyzes the new regulations' impact on distillate fuel markets and evaluates the constraints and

'On March 15, 1985, the Environmental Protection Agency promulgated particulate standards for heavy-duty diesel engines in response to Section 202(a)(3) of the Clean Air Act as amended in 1977 (Federal Register, Vol. 50, No. 51, March 15, 1985, p. 10606). During the rulemaking process, heavy-duty diesel engine manufacturers expressed concern that sulfur in diesel fuel could either plug the trapoxidizers that would be needed to meet the proposed particulate standards or generate significant particulate sulfate emissions that would make it difficult to meet the standards.

${ }^{2}$ Public Law 101-549, Section 211(i), U.S.C. 42, "Clean Air Act Amendments of 1990," enacted on November 15, 1990. Final rule announced by the Environmental Protection Agency in Federal Register, Vol. 55, No. 162, August 21, 1990, pp. 34120-34143, and revised in Federal Register, Vol. 57, No. 89, May 7, 1992, pp. 19535-19539.

${ }^{3}$ The Environmental protection Agency originally considered a cap on aromatics of 20 percent by volume. However, studies suggested that the benefits from particulate reductions (which did not include cancer benefits) did not justify the costs of reducing the level of aromatics in diesel fuel. Federal Register, Vol. 55, No. 162, August 21, 1990, pp. 34128-34129.

${ }^{4}$ An approximate inverse relationship exists between cetane number and aromatics. A cetane number of 45 corresponds to an aromatics concentration of about 27 volume percent while a diesel fuel with a 40 cetane number would contain about 36 voiume percent aromatics. Unzelman, George H., "Higher Diesel Quality Would Constrict Refining," Oil and Gas Journal (June 29, 1987), pp. 55-59.

${ }^{5}$ Energy Information Administration, Fuel Oil and Kerosene Sales 1991, DOE/EIA-0535(91) (Washington, DC, November 1992), p. 28, and Petroleum Supply Annual 1991, DOE/ElA-0340(91)/1 (Washington, DC, May 1993), p. 31.

"The California Air Resources Board (CARB) has independently enacted more stringent diesel fuel regulations, also due to take effect October 1, 1993. The new CARB regulations require on- and off-highway diesel fuel oil sold in California to meet both the 0.05 percent sulfur specification and a standard limiting aromatics to no more than 10 percent by volume. The regulations provide an exemption from the iatter requirement for certified diesel fuel blends which meet the low sulfur requirement and achieve emissions equivalent to a standard 10 volume percent aromatics diesel. 
costs faced by the petroleum refining industry in complying with them. The chapter reviews recent trends in demand and quality of on-highway diesel fuel oil and presents short- and long-term forecasts of diesel fuel demand. It discusses domestic and foreign sources of low-sulfur diesel supply, and then moves on to an analysis of distillate fuel desulfurization economics, including diesel fuel price seasonality, desulfurization variable and capital costs, sulfur dioxide $\left(\mathrm{SO}_{2}\right)$ emissions trading allowances, and the economics of blending lighter, more expensive petroleum fractions such as kerosene into diesel fuel. The chapter concludes with a brief review of events in Los Angeles in January 1985, when the California Air Resources Board reduced the sulfur specification for diesel fuel from 0.5 percent to 0.05 percent by weight.

\section{Distillate Fuel Oil Demand}

Distillate fuel oil is classified into two primary types: diesel fuel and heating oil. On-highway diesel fuel represents about 46 percent of the total domestic demand for distillate fuel. The East Coast, Petroleum Administration for Defense (PAD) District I, and Midwest (PAD District II) account for about two-thirds of the total on-highway diesel fuel market (Table 1).

Since 1979, the average sulfur level in No. 2 diesel has ranged from about 0.25 percent to 0.30 percent by weight, based on annual surveys conducted by the National Institute for Petroleum and Energy Research (NIPER).? About 0.45 million barrels per day of distillate fuel production already meets the 0.05 weight percent sulfur standard, about 1.8 million barrels per day falls in the $0.05-0.25$ weight percent range, and around 0.7 million barrels per day falls between 0.25 0.50 weight percent sulfur. ${ }^{8}$ The average cetane index of No. 2 diesel fuel produced in the United States has ranged between 45 and 47 from 1979 through 1992, according to the NIPER survey.

Demand for on-highway diesel fuel has shown steady growth of about 4.1 percent per year in the 1980's,

Table 1. Distillate Fuel Oil Sales by PAD Sub-District, 1991

(Thousand Barrels per Day)

PAD Sub-District

IA - New England ..............

IB - North Atlantic . . . . . . . . . . .

IC - South Atlantic . . . . . . . . . . . .

II - Midwest ................

III - Gulf Coast . . . . . . . . . . . . .

IV - Rocky Mountain ............

V - West Coast

$\ldots \ldots \ldots$

United States Total
On-Highway
Diesel

42.7

163.8

218.0

446.1

221.2

51.1

193.5

$1,336.3$
Residential and Commercial
Industrial and Other
Total Distillate

Source: Energy information Administration, Fuel Oil and Kerosene Sales 1991, DOE/EIA-0535(91) (Washington, DC, November 1992), pp. 30-33.

\footnotetext{
7The NIPER survey represents a nonrandom sample of U.S. refineries. In 1992, for example, analytical data for properties of 96 diesel fuel oil samples were submitted to NIPER. The samples were obtained during July and August 1992 from diesel product manufactured by 20 petroleum refining companies in 55 domestic refineries. National Institute for Petroleum and Energy Research, Diesel Fuel Oils, 1992 , NIPER-177 PPS 92/5 (Bartlesville, OK, October 1992).

"Energy Information, Ltd., "US Refiners Gear Up To Meet New Low-Sulfur Diesel Standards," Oil Market Listentr (New York, NY, January 19, 1993), p. 2.
} 
while demand for other distillates has remained flat (Figure 1). Sales of diesel fuel for on-highway use increased from an average 1.09 million barrels per day in 1984 (38.4 percent of total distillate sales) to 1.34 million barrels per day in 1991 (45.8 percent of total distillate sales).

On-highway diesel fuel has also captured an increasing share of the o r-highway fuel market (diesel plus motor gasoline). On highway diesel fucl's share of the total U.S. market for motor gasoline and diesel fuel rose from 14.0 percent in 1984 to 16.2 percent in 1991. Diesel fuel's increasing share of the on-highway fuel market results from slower gains in diesel vehicle fuel efficiency compared with motor gasoline vehicles rather than differences in highway mileage (Table 2).

Diesel fuel sales for automobile use are relatively inconsenuential. Sales of diesel powered cars in the United States grew rapidly from 0.35 percent of all new automobiles (diesel and gasoline) sold in 1977 to a peak of 6.10 percent by 1981 . Since 1981 , however, the diesel engine share of the U.S. new car market has declined steadily. The U.S. diesel new-car market share has averaged only 0.9 percent over the last 5 years (1987 to 1991)." Diesel car sales in several European countries, on the other hand, have continued to grow, exceeding
25 percent of 1988 new car sales in France and Belgium and over 10 percent in West Germany, Italy, and the Netherlands. ${ }^{10}$

\section{Figure 1. On-Highway Diesel and Other Distillate Sales}

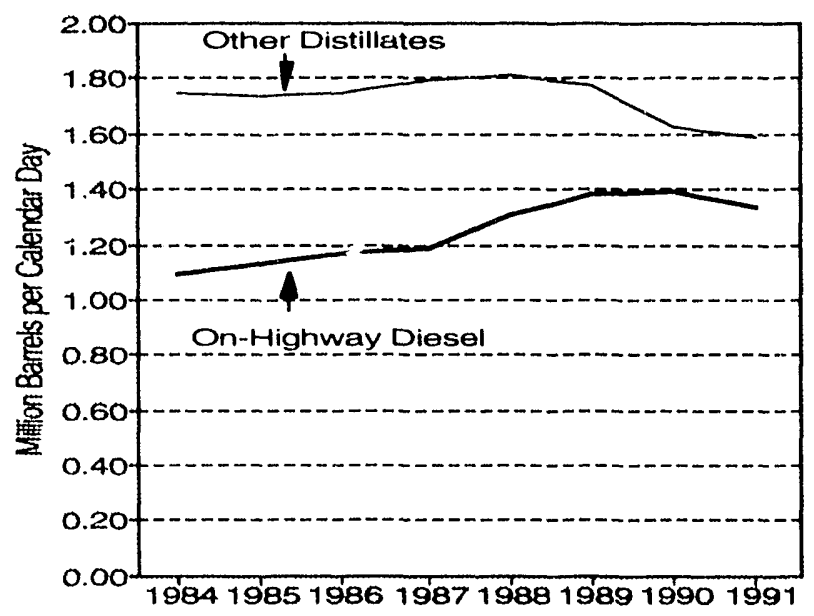

Sources: Energy Information Administration, Fuel Oil and Kerosene Sales 1991, DOE/EIA-0535(91), (Washington, DC, November 1992), p. 28, and Petroleum Marketing Annual 1988, DOE/EIA-0487-(88), (Washington, DC, Octobər 1989), p. 398.

\section{Table 2. Autumobile Versus Truck Highway Traffic}

\begin{tabular}{|c|c|c|c|c|}
\hline \multirow[b]{2}{*}{ Year } & \multicolumn{2}{|c|}{$\begin{array}{l}\text { Annual Miles Traveled } \\
\text { (millions) }\end{array}$} & \multicolumn{2}{|c|}{$\begin{array}{c}\text { Average Miles Traveled } \\
\text { per Gallon Fuel }\end{array}$} \\
\hline & $\begin{array}{c}\text { Personal } \\
\text { Passenger Vehicles }\end{array}$ & $\begin{array}{l}\text { Combination } \\
\text { Trucks }\end{array}$ & $\begin{array}{c}\text { Personal } \\
\text { Passenger Vehicles }\end{array}$ & $\begin{array}{c}\text { Combination } \\
\text { Trucks }\end{array}$ \\
\hline$\ldots \ldots$ & $1,269,651$ & 79,600 & 18.28 & 5.21 \\
\hline $1988 \ldots \ldots \ldots \ldots \ldots \ldots$ & $1,439,603$ & 90,158 & 19.95 & 5.27 \\
\hline $1989 \ldots \ldots \ldots \ldots \ldots \ldots$ & $1,488,140$ & 95,349 & 20.40 & 5.45 \\
\hline $1990 \ldots \ldots \ldots \ldots \ldots$ & $1,522,846$ & 96,367 & 21.10 & 5.52 \\
\hline$\ldots \ldots \ldots \ldots \ldots$ & $1,542,846$ & 96,949 & 21.76 & 5.65 \\
\hline Percent change 1985-1991 . . . . & $21.5 \%$ & $21.8 \%$ & $19.0 \%$ & $8.4 \%$ \\
\hline
\end{tabular}

Note: Combination trucks represent truck-tractors with semi-trailer(s) and a majority of the heavy single-unit trucks used regularly in combination with full trailer(s).

Source: Federal Highway Administration, Highway Statistics 1991, FHWA-PL-92-025 (Washington, DC, 1992), p. 193, and previous issues.

"Ward's Communications Inc. Wart's 1992 Automolin' Yearlook (Detroit, MI, 1992), p. 57, and Ward's 1988 Automotive Yearbook (Detroit, Mi, 1988$),$ p. 58.

"Ward's Communications Inc., Ward's 1989 Antomotio' Yearbonk (Detroit, MI, 1989), p. 86. 
The short-term forecast of distillate fuel demand prepared by the Energy iniurmation Administration and published quarterly in the Short-Term Energy Outlook (Outlook) represents the sum of distillate fuel demand in four sectors of the economy: industrial, residential and commercial, electric utility, and transportation. Distillate demand in the transportation sector includes vessel bunkering, military use, railroad use, and on-highway diesel fuel. On-highway diesel fuel represents about 77 percent of transportation sector distillate demand. The second quarter 1993 Outlook projects distillate demand in the transportation sector to grow by about 2.4 percent in 1993 and 3.9 percent in 1994 (Table 3).

The long-term (20-year) forecast of distillate fuel consumption in the transportation sector shows annual growth of 1.7 percent per year between 1990 and 2010 (42 percent total growth). Fuel consumption by freight trucks is projected to grow steadily at a rate of about 1.3 percent per year (total growth of about 30 percent between 1990 and 2010). Growth in truck travel follows trends in economic activity slosely, although fuel consumption by trucks is projected to rise more slowly than real gross domestic product because fuel efficiency is expected to improve by about 11 percent between 1990 and 2010." Diesel trucks are expected to capture a greater share of the short-haul market. In 1989, 54 percent of all energy consumed by freight trucks came from diesel fuel. By 2010, diesel-powered trucks are expected to represent 63 percent of freight truck fuel consumption. ${ }^{12}$

\section{Low-Sulfur Distillate Supply}

Because diesel fuel and heating oil are currently so similar, most refineries produce a distillate product that satisfies both diesel and heating oil quality restrictions rather than incur the cost of segregating blend stocks and finished products. According to the National Petroleum Refiners Association (NPRA), if fuel distribution practices that were in place in 1986 are maintained, about 2.4 million barrels per day of distillate fuel oil would have to meet the low-sulfur requirement. However, only about one-half of this distillate fuel is required for the on-highway diesel fuel market. ${ }^{1.3}$ Segregation of on-highway diesel fuel from other distillates within refineries would reduce desulfurization plant investment and operating costs. However, these savings could be more than offset by increased capital and operating costs for additional tankage and inventories in refineries, product distribution systems, and terminals.

Table 3. Transportation Sector Distillate Fuel Demand Short-Term Forecast (Million Barrels per Day)

\begin{tabular}{|c|c|c|c|c|c|}
\hline Year & First Quarter & Second Quarter & Third Quarter & Fourth Quarter & Annual Average \\
\hline 1991 & 1.621 & 1.780 & 1.810 & 1.705 & 1.730 \\
\hline 1992 & 1.684 & 1.815 & 1.826 & 1.747 & 1.768 \\
\hline 1993 & 1.720 & 1.834 & 1.872 & 1.815 & 1.811 \\
\hline 1994 & 1.779 & 1.906 & $1.94 / j$ & 1.890 & 1.881 \\
\hline
\end{tabular}

Note: On-highway diesel-fuel represents about 77 percent of transperiation sector's distillate fuel demand.

Source: Energy Information Administration, Short-Term Integrated Forecasting System (STIFS) database, "Transportation Sector Distillate Fuel Demand," series DFACPUS, extracted June 18, 1993.

\footnotetext{
"Energy Information Administration, Annual Energy Oullook 1993, DOE/EIA-0383(93) (Washington, DC, January 1993), pp. 25, 82, 96.

"Energy Information Administration, Annual Energy Oullook 1992, DOE/EIA-0383(92) (Washington, DC, January 1992), p. 22.

"National Petroleum Refiners Association, LIS. Refining' Industry Capability to Manufacture Ulira Low Sulfur Diesel Fuels, (Washington, DC, 1986), pp. 1,3. Refineries in the 1986 NPRA survey produced 428,000 barrels per day of segregated diesel fuel, 220,000 barrels per day of segregated No. 2 heating (ill, and 1,934,000) barrels per day of unsegregated distillate fuel. The 139 refineries responding to the survey represented a total of 14.4 million barrels per day of crude oil distillation capacity (about 98 percera of operating capacity as of January 1, 1986).
} 
Because providing low-sulfur fuel may be prohibitively expensive for some refineries, segregation of fuels between refineries is likely. Some refineries may produce only low-sulfur diesel fuel while other refineries may produce only high-sulfur distillates for the off-highway and heating oil markets. Refiners unable to produce low-sulfur diesel fuel may abandon the on-highway diesel market or exchange product with refineries producing low-sulfur diesel fuel.

Refiners who participate in the low-sulfur diesel market have four primary options for supplying low-sulfur diesel fuel oil:

- Increase operating severity of existing or new catalytic hydrotreating units through use of more active catalysts or changes in unit operating conditions (temperature, pressure, space velocity, hydrogen-to-oil ratios, etc) ${ }^{14}$

- Increase production of low-sulfur distillates from catalytic hydrocracking units. Catalytic hydrocracking units are normally operated to convert vacuum gas oil or light cycle oils to naphtha for catalytic reforming into gasoline. Selective production of distillate through use of different operating conditions and catalysts is also possible.

- Restrict diesel fuel blending operations to lowsulfur internal refinery streams. Some low-sulfur refinery streams not normally blended into distillate fuels, such as kerosene, could be used for on-highway diesel fuel blending.

- Import low-sulfur diesel fuel.

The refining industry's capability to produce low-sulfur on-highway diesel fuel remains uncertain. It is not clear how many refiners may abandon the on-highway diesel fuel market, what is the rated capacity of existing desulfurization equipment to produce low-sulfur diesel fuel, how strong is the demand for desulfurization capacity by other distillate fuel products, and how large is the capacity of new distillate desulfurization plants planned or under construction. However, most industry reports indicate that there will be sufficient supply of low-sulfur on-highway diesel by the October 1, 1993, CAAA90 deadline. ${ }^{15}$
Hydrotreating and Hydrocracking Capacity: Diesel fuel sulfur reduction is accomplished by either catalytic hydrotreating of distillate fuel or catalytic hydrocracking of heavy fuels such as residual fuel oil into low-sulfur distillate. The amount of desulfurization capacity available will affect the amount of capital investment required for compliance with the new sulfur regulations. However, the capability of existing desulfurization capacity to produce low-sulfur diesel fuel is highly uncertain. Some existing catalytic hydrotreating capacity must remain in kerosene or heating oil treatment service while catalytic hydrocracking capacity will continue to maximize gasoline production. Furthermore, increasing the level of sulfur removal requires operating desulfurization units under more severe conditions (increased hydrogen volume, higher temperature and pressure, and lower reactor space velocities), which reduces unit capacity because of shorter catalyst life and lower reactor space velocities. Thus, the increase in desulfurization unit operating severity needed to produce low-sulfur diesel fuel will significantly reduce the rated operating capacity of existing units.

NPRA estimated that full practical utilization of existing distillate hydrotreating capacity $(1,675,000$ barrels per day in their 1986 survey) could result in the production of only 315,785 barrels per day of 0.05 weight percent sulfur diesel fuel by 21 refineries." Between January 1, 1987, and January 1, 1993, operable crude oil distillation capacity decreased by 3.2 percent while distillate hydrotreating capacity increased by 9.2 percent (or 238,667 barrels per stream day). Additional distillate hydrotreating capacity expansions of 705,720 barrels per day have been announced (Table 4).

Of the 187 refineries which were operable on January 1 , 1993, 94 refineries did not have distillate hydrodesulfurization units. The 94 refineries without distillate hydrodesulfurization capacity represent about 19 percent of total domestic refining capacity. ${ }^{17}$ Most of these refineries are not expected to produce lowsulfur diesel fuel. Only 12 of these refineries have announced construction of new distillate hydrodesulfurization units. ${ }^{18}$

\footnotetext{
${ }^{14}$ PennWell Publishing Co., "1990s Fuel Specifications Will Require Process Changes," Oil and Gas fourmal, (February 26, 1990), pp. 83-87.

${ }^{15}$ See, for example, Energy Information Ltd., "Ample U.S. Refining Capacity Expected for New Low-Sulfur Diesel Needs," Oil Market Listener, (New York, NY, March 4, 1993), p. 1.

"National Petroleum Refiners Association, U.S. Refining Industry Cupability to Manufacture Ullra Low Sulfur Dies'l Fucls, (Washington, DC, 1986), pp. 1-2.

17Energy Information Administration, Petrole'um Supply Anmual 1992, DOE/EIA-0340(92)/1 (Washington, DC, May 1993), pp. 82-105.

"Based on periodic industry announcements of plants under construction.
} 
Table 4. U.S. Distillate Hydrotreating Capacity by PAD District, January 1, 1993

(Barrels per Stream Day, Percent of Atmospheric Distillation Capacity in Parentheses)

\begin{tabular}{|c|c|c|c|c|c|}
\hline \multirow{2}{*}{ PAD District } & \multirow{2}{*}{$\begin{array}{c}\begin{array}{c}\text { Crude Oil } \\
\text { Atmospheric } \\
\text { Distillation }\end{array} \\
1,425,000\end{array}$} & \multicolumn{2}{|c|}{$\begin{array}{l}\text { Existing Distillate } \\
\text { Hydrotreating Capacity }\end{array}$} & \multicolumn{2}{|c|}{$\begin{array}{c}\text { Additional } \\
\text { Planned Distiliate } \\
\text { Hydrotreating Capacity }\end{array}$} \\
\hline & & 366,600 & $(25.7)$ & 20,000 & $(1.4)$ \\
\hline$\|$ - Midwest & $3,533,120$ & 460,000 & $(13.0)$ & 376,500 & $(10.7)$ \\
\hline III - Gulf Coast & $7,106,450$ & $1,559,625$ & $(21.9)$ & 213,620 & (3.0) \\
\hline IV - Rocky Mountain & 537,750 & 96,100 & $(17.9)$ & 12,000 & (2.2) \\
\hline V - West Coast & $2,958,679$ & 360,200 & (12.2) & 83,600 & (2.8) \\
\hline United States Total & $15,560,999$ & $2,842,525$ & (18.3) & 705,720 & (4.5) \\
\hline
\end{tabular}

Notes: Existing distillate hydrotreating capacity includes kerosene and jet kero treaters.

Sources: Existing capacity from Energy Information Administration, Petroleum Supply Annual 1992, DOE/EIA-00340(92/1), (Washington, DC, May 1993). Planned capacity from PennWell Publishing Co., Oil and Gas Journal, (Tulsa, OK, April 12, 1993), pp. 55-57; Gulf Publishing Co., Hydrocarbon Processing. (Houston, TX, October 1992), pp. 6-12; and company announcements in industry publications.

Blending Kerosene into Diesel Fuel: Small increases in low-sulfur diesel fuel can be obtained by blending in lighter, more expensive petroleum fractions such as No. 1 distillate or kerosene. Surveys taken by the National Institute for Petroleum and Energy Research (NIPER) show that the average sulfur contents of Jet- $A$ and No. 1 diesel are close to 0.05 weight percent. Kerosene-type jet fuel is the largest of these potential sources with 1991 average sales of 1.3 million barrels per day. Kerosene or No. 1 distillate is routinely blended into diesel fuel during the winter to lower the cloud point (the temperature at which a cloud of wax crystals first appears) and prevent plugging of fuel lines. In some cold northern States, distillate blends containing 30 to 50 percent kerosene are common. ${ }^{14}$

Distillate Imports: Distillate fuel imports into the United States come primarily from three sources: Canada, Venezuela, and the Virgin Islands. In 1992, these three sources accounted for over 93 percent of the average 216,000 barrels per day of distillate fuel imported into the United States. Over the last 6 years, these three sources have accounted for over 86 ; percent of distillate fuel imports. ${ }^{21}$

The ability of these primary foreign distillate fuel oil suppliers to provide low-sulfur diesel fuel depends on their catalytic hydrotreating capacity (Table 5) and ability to segregate low-sulfur internal refinery distillate streams. The Virgin Islands (Hess) refinery is reported to have the largest ratio of distillate hydrotreating to crude oil distillation capacity and may be capable of supplying low-sulfur diesel to the U.S. East Coast. Venezuela, on the other hand, has the lowest ratio of hydrotreating to crude oil distillation capacity. However, Venezuela's U.S. exports of distillate represents only about 17 percent of its total distillate production compared to about 33 percent of the Virgin lslands. ${ }^{21}$

\footnotetext{
"Hunter Publishing Co., "Diesel Fuel Additives: Growing Business for Petroleum Marketers," National Potrollum Nous (Dess Plaines, II., February 1992), 42-45.

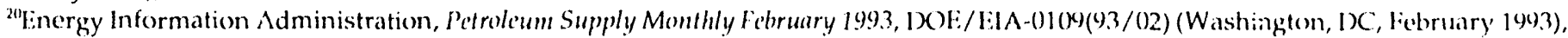
p. 80, and Potrol'um Supply Anmual 1992, DOE/EIA-0340(92)/1 (Washington, DX, May 1493), p. 53-56, and earlier issuses.

${ }^{21}$ Energy Information Administration, International Energy Annual 1991, DOE: /:IA-(0219(91) (Washington, 1) C, December 1992), p. 42.
} 
Table 5. Foreign Distillate Hydrotreating Capacity, January 1, 1993

(Barrels per Calendar Day)

\begin{tabular}{|c|c|c|c|c|}
\hline Country & $\begin{array}{l}\text { Number of } \\
\text { Refineries }\end{array}$ & $\begin{array}{l}\text { Crude Oil } \\
\text { Distillation } \\
\text { Capacity }\end{array}$ & $\begin{array}{c}\text { Distillate } \\
\text { Hydrotreating } \\
\text { Capacity }\end{array}$ & $\begin{array}{l}\text { Hydrotreating as } \\
\text { Percent of Crude } \\
\text { Distillation } \\
\text { Capacity }\end{array}$ \\
\hline Canada & $? 6$ & $1,871,500$ & 314,500 & 16.8 \\
\hline Venezuela & 6 & $1,167,000$ & 95,300 & 8.2 \\
\hline Virgin Islands & 1 & 545,000 & 165,000 & 30.2 \\
\hline
\end{tabular}

Source. PernWell Publishing Co., Oil and Gas Journal (Tulsa, OK, Dec. 21, 1992), pp. 52-95.

Because Europe has led the United States in increasing restrictions on diesel fuel quality in recent years, European refiners may also be unable to provide lowsulfur diesel for export. The maximum sulfur content for diesel and heating oil is 0.2 by weight percent in eight countries (Belgium, Denmark, Finland, Germany, Luxem'surg, Netherlands, Norway, and Sweden) and 0.3 percent by weight in seven (France, Greece, Ireland, Italy, Spain, Portugal, and the United Kingdom). Austria and Switzerland have a maximum sulfur cuntent of 015 percent by weight in diesel fucl and 1 percent in heating oil. ${ }^{22}$ The European community proposes to limit sulfur in all gas oils and distillates to 0.2 percent by weight by October 1, 1994. A further reduction in the sulfur level of on-highway diesel fuel to 0.05 percent will be required by October 1, 1996 .

\section{Distillate Desulfurization Economics}

The increase in operating costs and new capital investment required to produce low-sulfur diesel fuel should yield a price premium for low-sulfur diesel over heating oil and other high-sulfur distillate fuels. The significant factors in assessing the market price premium for low-sulfur diesel fuel are: 1) the variable costs of operating desulfurization units; 2) the capital cost of new desulfurization capacity required to produce low-sulfur diesel fuel; and 3 ) the availability of other low-sulfur refinery streams which are not normally blended into distillate fuels (such as kerosene) but which could be used for on-highway diesel fuel blending.
Several industry studies have estimated the incremental cost of producing low-sulfur distillate fuel to be in the range of 1.2 cents to 7.0 cents per gallon. ${ }^{23}$ The analysis presented here projects a low-sulfur diesel market price premium of 3 to 4 cents per gallon over heating oil based on costs faced by the "marginal" producer. This premium covers higher variable costs of about 1 cent per gallon and capital recovery costs of 2 to 3 cents per gallon. This price premium is consistent with blending of incremental barrels of kerosene into the low-sulfur diesel pool and the observed market response to the low-sulfur diesel regulations imposed by California's South Coast Air Quality Management District (Los Angeles) in 1985.

Not all refiners vill respond the same way to the new low-sulfur ma ket constraint. Some refiners may abandon production of low-sulfur diesel fuel completely. For example, even though the cost to small refiners may be lowered by the $\mathrm{SO}_{2}$ trading allowances, these credits may not be enough to offset the higher production and capital costs they face. Desulfurization variable production costs are estimated to range from 0.7 cent per gallon for large refiners to 3.1 cents per gallon for small refiners. Capital service costs for new desulfurization capacity are projected to range from 1.1 cents per gallon for large refiners to 7.0 cents per gallon for small refiners. The net cost to small refiners may be lower by about 0.2 cent to 2.4 cents per gallon because of allowances for sulfur dioxide emissions which may be sold.

\footnotetext{
"Energy Information Ltd., "Low Sulfur Diesel Oil Moves to Center Stage in European Environmental Debate," Oil Market Listener, (New York, NY, March 13, 1992), p. 2

'Energy Resource Consultants, Inc. and Sobotka Consultants, Inc., Diesel Fuel Quality Effects on Emissions, Durability, and Performance (Washington, DC, September 30, 1985). National Petroleum Refiners Association, U.S. Refining Irdustry Capability to Manufacture Ultra Low Sulfur Dirsel Fueis, (Washington, DC, 1986). Environmental Protection Agency, Federal Register, Vol. 54, No. 163 (August 24, 1989), p. 35278. Cambridge Energy Research Associates, The U.S. Refining Industry: Facing the Challenges of the 1990s (Cambridge, MA, January 1992).
} 
Diesel Fuel Price Seasonality: Although demand for diesel fuel is highest in the summer months, diesel fuel prices are expected to remain tied to heating oil, a seasonal fuel with a winter peak in demand and prices (Figure 2). ${ }^{24}$ Because a significant proportion of the winter supply of heating oil must come from inventory, an incentive must exist for refiners to store distillates produced during the low heating oil demand summer months for delivery during the winter heating season. The price of distillate fuel oil typically swings by about 10 cents per gallon from a June low to a December peak and provides this incentive. ${ }^{25}$

Because of this swing in distillate price a from June low to a December high, there will be no incentive for refiners to produce low-sulfur on-highway diesel fuel during the winter for delivery is the high diesel fuel demand summer months (which would be equivalent to a "buy high - sell low" strategy). Thus, low-sulfur diesel fuel production capacity must be sufficient to meet the peak summer diesel fuel demand. This requirement implies that there may be excess low-sulfur diesel fuel production capacity during the winter. Under such conditions, refiners may be able to recover variable costs but not capital costs in the low-suifur diesel fuel price premium. However, two factors will serve to reduce this potential winter excess capacity condition. First, since the swing in diesel fuel demand is only about 21 percent of peak summer demand, normal desulfurization unit turnarounds (e.g., catalyst replacement) would be scheduled for winter months thereby minimizing excess capacity. Second, because total distillate fuel oil demand is lowest during the summer, some heating oil desulfurization capacity would be available during the summer months for lowsulfur diesel production.

Desulfurization Variable Costs: Increasing the level of sulfur removal from distillate fuel requires operation of hydrodesulfurization units under more severe operating conditions (increased hydrogen volume, higher temperature and pressure, and lower reactor space velocities) which increases operating costs.

Refineries responding to the 1986 NPRA survey claimed that the increase in desulfurization variable costs would range from 0.7 to 3.1 cents per gallon of low-sulfur distillate fuel, depending on capacity (Table 6). The average for the United States is closer to the lower end of this range (at 0.9 cents per gallon), with higher unit

\section{Figure 2. Diesel and Heating Oil Demand Six-Year Average, 1986-1991}

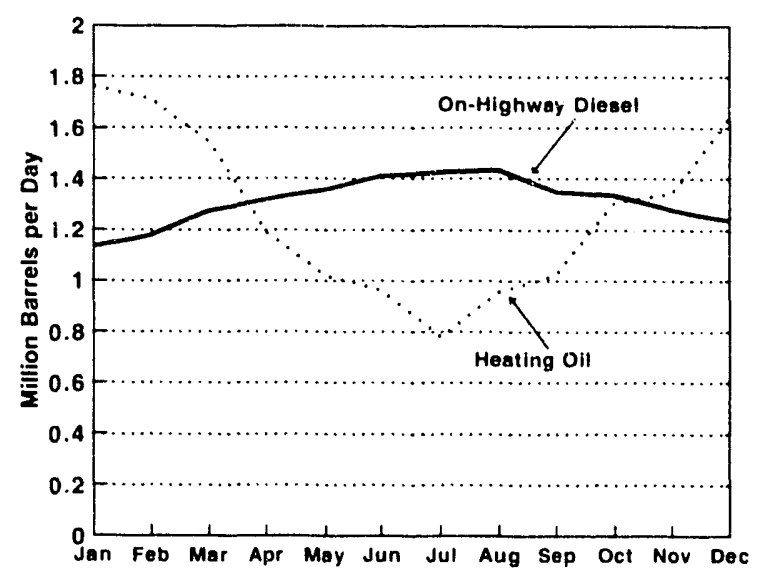

Sources: - Heating oil from Energy Information Administration, Integrated Modeling Data System (IMDS) database, "Distillate Fuel Industrial Sector," series DFICPUS, and "Distillate Fuel - Residential and Commercial Sectors," series DFHCPUS (extracted june 18, 1993). - On-highway diesel from Federal Highway Administration. Highway Statistics 1991, FHWA-PL-92-025 (Washington, DC, 1992), p. 8 , and other annual issues.

costs being characteristic of the smaller (and less complex) refineries. Small refineries are disadvantaged because they typically do not have access to inexpensive hydrogen (which is produced as a byproduct from naphtha reformers) and cannot benefit from economies of scale because they do not have existing desulfurization capacity to build on.

Desulfurization Capital Costs: Estimated capital costs in the 1986 NPRA survey ranged from $\$ 660$ per barrel of low-sulfur distillate for large refiners to $\$ 4,328$ per barrel of low-sulfur distillate for small refiners. Estimated capital service charges ranged from 1.1 cents per gallon of low-sulfur distillate fuel for large refiners to 7.0 cents per gallon of low-sulfur distillate produced for small refiners (Table 7). The average for the United States is again closer to the lower end of this range (at 2.2 cents per gallon). The estimated capital service cost for large refineries is significantly lower than that for small refineries because of economies of scale and the availability of existing hydrogen production and sulfur recovery capacity, which reduces necessary capital investment.

\footnotetext{
${ }^{24}$ Differences in the average refiner prices for diesel fuel and heating oil are usually less than 1 cent per gallon. The reported price differences may result from averaging different regional prices and market shares or price premiums on special diesel fuel blends which include additives such as pour point and cloud point depressants used in the winter.

"Author's calculation using regression analysis of diesel fuel price from 1982 to the present (controlling for changes, in deseasonalized crude oil price).
} 
Table 6. NPRA Survey Estimates of Low-Sulfur Distillate Variable Production Cost

\begin{tabular}{|c|c|c|c|}
\hline $\begin{array}{c}\text { Refinery Size Range } \\
\text { (thousand barrels per day) }\end{array}$ & $\begin{array}{l}\text { Number of } \\
\text { Refineries }\end{array}$ & $\begin{array}{l}\text { Potential Low-Sulfur } \\
\text { Distillate Production } \\
\text { (thousand barrels per day) }\end{array}$ & $\begin{array}{l}\text { Estimated } \\
\text { Operating Expense } \\
\text { (cents per gallon) }\end{array}$ \\
\hline 0 to 30 & 25 & 64 & 3.1 \\
\hline 30 to 100 & 67 & 821 & 1.0 \\
\hline 100 to $200 \ldots \ldots \ldots \ldots$ & 28 & 734 & 0.9 \\
\hline Over $200 \ldots \ldots \ldots \ldots$ & 19 & 843 & 0.7 \\
\hline United States Total & 139 & 2,462 & 0.5 \\
\hline
\end{tabular}

Source: National Petroleum Refiner's Association, U.S. Refining Industry Capacity to Manufacture UItra Low Sulfur Diesel Fuels, (Washington, DC, 1986), pp. 30 and 32.

Table 7. NPRA Survey Estimates of Low-Sulfur Distillate Capital Cost

\begin{tabular}{|c|c|c|c|c|}
\hline $\begin{array}{c}\text { Refinery Size Range } \\
\text { (thousand barrels per day) }\end{array}$ & $\begin{array}{l}\text { Number of } \\
\text { Refineries }\end{array}$ & \multicolumn{2}{|c|}{ Capital Investment New Facilities } & $\begin{array}{c}\text { Capital Service } \\
\text { (cents per gallon } \\
\text { low-sulfur distillate) }\end{array}$ \\
\hline 100 to $200 \ldots \ldots$ & 28 & 852 & 1,161 & 1.0 \\
\hline Over $200 \ldots \ldots$ & 19 & 556 & 660 & 1.1 \\
\hline United States Total . . & 139 & 3,313 & 1,345 & 2.2 \\
\hline
\end{tabular}

Source: National Petroleum Refiner's Association, 1/.S. Refining Industry Capacity to Manufacture Ultra Low Sulfur Diesel Fuels, (Washington, DC, 1986), pp. 30 and 32. Capital service charge based on 15 percent discounted cash flow return on investment with a 13-year economic life.

Some refineries may not be able to make the needed investment in catalytic hydrogenation, hydrogen production, and sulfur recovery units. These refineries may have to abandon the on-highway diesel fuel market. The National Petroleum Council (NPC) describes this as a "niche" strategy, focused on home heating oil and off-highway diesel fuel, and most likely followed by small refineries. ${ }^{26}$ Refineries which do not produce low-sulfur distillate may arrange for product exchanges of heating oil for low-sulfur diesel produced by refiners with excess desulfurization capacity, with appropriate value adjustments.

Thirty-seven refineries in the NPRA survey, with a distillate production capacity of about 415,000 barrels per day, indicated that they could not make the needed improvements in diesel fuel quality because of investment capital or environmental permitting

\footnotetext{
${ }^{2 n}$ National Petroleum Council, Petroleum Refining in the 1990s; Meeting the Challenges of the Clean Air Act (Washington, DC, June 1991), p. 55.
} 
constraints. The small and medium refineries in the NPRA survey were reported to be the most susceptible to these constraints, with 33 out of 92 small and medium refineries being unable to build new facilities. Fifty-six percent of small refineries (less than 30,000 barrels per day crude oil capacity) and 28 percent of medium sized refineries (30,000 to 100,000 barrels per day of crude oil capacity) reported being unable to build new desulfurization units.

Sulfur Dioxide Emissions Allowances: Because small refiners would face greater capital and operating costs to meet the new low-sulfur standard than larger refiners, CAAA90 grants sulfur dioxide $\left(\mathrm{SO}_{2}\right)$ allowances to small refiners that produce complying onhighway diesel fuel. Small refiners may sell their $\mathrm{SO}_{2}$ allowances to other sources affected by the CAAA90 (e.g., electric utilities which burn high-sulfur coal), or bank them for future use. CAAA90 defines small refiners as those companies with average 1990 crude oil throughput of 137,500 barrels per calendar day or less, and further stipulates that the crude oil throughput of individual qualifying refineries be 50,000 barrels per calendar day or less. Based on EIA Form 810, "Monthly Refinery Report," 90 refineries, which accounted for 12.9 percent of total U.S. distillate production in 1990, may qualify for allowances.

One $\mathrm{SO}_{2}$ allowance corresponds to 1 ton $(2,000$ pouncis) of sulfur dioxide. For typical diesel fuel (32.4 API gravity), about 1,478 barrels of low-sulfur diesel fuel would be awarded one $\mathrm{SO}_{2}$ allowance. ${ }^{27}$ The value of these allowances ranges from $\$ 131$ to $\$ 1,500$ each. ${ }^{2 *}$ This corresponds to a credit to small refiners of 0.2 cent to 2.4 cents per gallon of low-sulfur diesel fuel produced.

The maximum number of allowances that can be allocated annually to a small refiner is 1,500 , which would correspond to low-sulfur diesel production of about 6,075 barrels per calendar day. In any given year, the total number of allowances awarded to all small refiners may not exceed 35,000) (about 141,750) barrels per day of low-sulfur diesel). Allowances may be allocated to small refiners from October 1, 1993, through December 31, 1999.

Blending Kerosene into Diesel Fuel: Small increases in low-sulfur diesel fuel supply can be obtained by blending in lighter, more expensive petroleum fractions such as No. 1 distillate or kerosene. Over the last 5 years, the spot price of jet kerosene waterborne cargoes on the U.S. Gulf Coast (USGC) has averaged 2.9 cents per gallon higher then the spot USC,C waterborne No. 2 fuel oil price (excluding the Iraq "Desert Shicld" months). ${ }^{29}$ This option should be viewed only as a spot or short-term solution to low-sulfur diesel fuel supply. Kerosene blend stocks are of lower quality than diesel fuel because of their lower heating values, which would yield lower diesel engine fuel efficiency. Furthermore, proposed U.S. military conversion from JP-4 naphtha-type jet fuel to JP-8 or Jet- $A$ jet kerosene will place greater demand pressure on the price of the kerosene cut of the crude oil barrel, tending to reduce the cost effectiveness of blending jet kero into diesel fuel. ${ }^{30}$

Transportation and Distribution: NPC has noted that changing patterns of transportation and distribution could, in some regions, bring about "relatively modest" increases in the costs of moving product from supply to market. Cost increases could result from either having to move diesel fuel longer distances because fewer refineries will be producing on-highway diesel, or from having to build additional infrastructure to allow segregation of low-sulfur diesel fuel. ${ }^{31}$

The Petroleum Marketers Association of America (PMAA) argued that it would cost small marketers an

\footnotetext{
${ }^{27}$ Environmental Protection Agency, Federal Register, Vol. 57, No. 130 (July 7, 1992), p. 30031. The amount of sulfur removed in production of low-sulfur diesel is assumed by the EI'A to represent the reduction in average sulfur content from (1.274 percint 10 ().(050) percent sulfur by weight.

${ }^{24}$ Environmental Protection Agency, Federal Register, Vol. 58, No. 88 (May 10, 1993), pp. 27563-.7567. The low end of the range corresponds to the low winning bid of $\$ 1.31$ by American Electric Power Service in the March 29,1943 I'hase 1 spot auction conducted by the Chicago Board of Trade for the EPA. The $\$ 1,500$ high end of the range represents the fixed price of allewances that the fil'A will put up for direct sale on June 1, 1993, on a first-come, first-served basis.

${ }^{24}$ McCiraw-Hill, Inc., Plall's (Oll Prict Hamdbook and Oilmanac (New York, NY, 1988-1992).

"Energy Information Administration, Annual Energy Outlook 1993, DOE/!:LA-0.383(93) (Washington, DC, January 1993), p. 35.

"Nationa! Petroleum Council, Petrolium Refining in the 1990); Meeting the Challenge's of the Clean Air Act, (Washington, I) ( Jume lyol), p. 56 .
} 
average of $\$ 40,000$ to upgrade storage facilities to handle segregated fuel and an average $\$ 60,000$ to handle the delivery of segregated fuels, with the average cost to handle segregated fuels being about 1.5 cents per gallon. ${ }^{32}$ A later study done by ICF Resources, Inc., for the Environmental Protection Agency (EPA), estimated costs to marketers of 0.1 cent to 0.4 cent per gallon depending on density of marketers, diesel share of distillate market, and population density. ${ }^{3.3}$

The Los Angeles Experience: One limited historical example of low-sulfur diesel fuel pricing is available. On January 1, 1985, the California Air Resources Board required all southern $C$ alifor.via refiners producing over $50,(0) 0$ barrels per day to reduce sulfur in diesel fuel sold in the South Coast Air Quality Management District (Los Angeles) from 0.5 percent to 0.05 percent. During the first week of 1985, Chevron offered 0.05 percent diesel at 2 cents per gallon more than highsulfur diesel, while ARCO priced its low-sulfur diesel at 4 cents per gallon above its high-sulfur diesel. ${ }^{34} \mathrm{~A}$ comparison of Platt's refinery and terminal price reports for the Los Angeles and San Francisco No. 2 distillate terminals reveals a possible premium of over 3 cents per gallon for diesel fuel sold in Los Angeles. During the 4 years before January 1,1985 , diesel fuel in Los Angeles averaged 1.5 cents per gallon less than San Francisco. In the 4 years after the regulation took effect, the price of diesel in Los Angeles was 1.7 cents per gallon more than the San Francisco price. ${ }^{35}$ Examining daily diesel rack price postings reveals that on January 2, 1985, Los Angeles had a price advantage of 0.625 cents per gallon (72.5 cents per gallon in Los Angeles versus 73.1 cents per gallon in San Francisco) which became a 4-cent per gallon disadvantage by January 11, 1985 (75.6 cents per gallon in Los Angeles versus 71.6 cents per gallon in San Francisco). Although this is supportive evidence of the 3- to 4cents-per-gallon market price premium for low-sulfur diesel fuel, it is not conclusive because of other unidentified market supply and demand forces that may have affected regional prices.

\section{Glossary}

Aromatics, Hydrocarbons characterized by unsaturated ring structures of carbon atoms. Commercial petroleum aromatics are benzene, toluene, and xylene (BTX).
Catalytic Hydrocracking. A refining process that uses hydrogen and catalysts with relatively low temperatures and high pressures for converting middle boiling or residual material to high-octane gasoline, reformer charge stock, jet fuel and/or high grade distillate fuel oil. The process uses one or more catalysts, depending upon product output, and can handle hirh sulfur feedstocks without prior desulfurization.

Catalytic Hydrotreating. A refining process for treating petroleum fractions from atmospheric or vacuum distillation units (e.g., naphthas, middle distillates, reformer feeds, residual fuel oil, and heavy gas oil) and other petroleum (e.g., cat cracked naphtha, coker naphtha, gas oil, etc.) in the presence of catalysts and substantial quantities of hydrogen. Hydrotreating includes desulfurization, removal of substances (e.g., nitrogen compounds) that deactivate catalysts, conversion of olefins to paraffins to reduce gum formation in gasoline, and other processes to upgrade the quality of the fractions.

Cetane Number. A measure of the ignition quality of diesel fuel oil. Cetane number is measured by comparing the ignition qualities of a diesel fuel in a test engine against those of a standard mixture of cetane and heptamethylnonane. The cetane "index" is calculated from the physical properties of the fuel such as API gravity and mid-boiling point and is a less expensive approximation of the cetane number.

Distillate Fuel Oil. A general classification for one of the petroleum fractions produced in conventional distillation operations. It is used primarily for space heating, on- and off-highway diesel engine fuel (including railroad and agricultural machinery), and electric power generation. Distillate fuel oil is classified into three grades (No. 1, No. 2, and No. 4) which are differentiated by the boiling range of the fuel.

No. 1 Distillate. A volatile distillate fuel with a boiling range between 300-575 degrees Fahrenheit which meets the specifications for No. 1 heating or fuel oil as defined in American Society for Testing and Materials (ASTM) Specification D 396 and/or specifications for No. 1 diesel fuel as defined in ASTM Specification D 975.

\footnotetext{
"Foderal Repister, Vol. 55, No. 162 (August 21, 1990), p. 34122.

"ICF, Inc., "Impacts of Fuel Desulfurization on Distillate Marketers," March 13, 199), cited in Fo'deral Re'gister, Vol. 55, No. 162 (August 21, 1990), pp. 34123-34125.

"Lnited Communications Group, "Arco, Chevron Peg Diesel Price," Oil Express (Silver Spring, MD, January 7, 1985), p. 3.

"McGraw-Hill, Inc., Platt's Oil Price' Handbock and Oilmanac (New York, NY, 1981-1988).
} 
No. 1 Diesel Fuel. Used in high-speed diesel engines generally operated under wide variations in speed and load. Includes Type C-B diesel fuel used for city buses and similar operations.

No. 1 Fuel Oil. A light distillate fuel oil intended for use in vaporizing pot-type burners.

No. 2 Distillate. A gas oil type distillate of lower volatility with distillation temperatures at the 90 -percent boiling point between 540-640 degrees Fahrenheit. No. 2 distillate me-ts the specifications for No. 2 heating or fuel oil as defined in ASTM D 396 and/or specifications for No. 2 diesel fuel as defined in ASTM Specification D 975.

No. 2 Diesel Fuel. Used in high speed diesel engines generally operated under uniform speed and load conditions. Includes Type $R-R$ diesel fuel used for railroad locomotive engines and Type T-T for diesel engine trucks.

No. 2 Fuel Oil. Used in atomizing type burners for domestic heating or for moderate capacity commercial-industrial bumers.

No. 4 Distillate. This grade is a blend of distillaie fuel oil and residual fuel oil stocks that conforms to ASTM Specification D 396 or Federal Specification VV-F-815C and/or specifications for No. 4 diesel fuel as defined in ASTM specification D 975.

No. 4 Diesel Fuel. Used as a bunker fuel for ships and for other low- and medium-speed diesel engines in sustained constant-speed service.

No. 4 Fuel Oil. Used for commercial burner installations not equipped with preheating facilities. It is used extensively in industrial plants. 


\section{Comparison of EIA and Other Forecasts for 1993 and 1994}

This chapter presents a comparison of EIA's energy forecasts for 1993 and 1994 (Tables 8 and 9), as published in the first quarter 1993 Short-Term Energy Outlook, with the forecasts of several other major U.S. energy forecasters All of the alternative forecasts were also published in the first quarter 1993. These forecasts are: DRI/McGraw-Hill (DRI), the WEFA Group (WEFA), National Economic Research Associates (NERA), and the American Gas Association (AGA), and the Independent Petroleum Association of America (IPAA). ${ }^{36}$ The forecasts were chosen on the basis of the forecast years covered as well as the inclusiveness of the energy data covered. The IPAA forecast, however, extends only through 1993 . The comparison focuses on the similarities and differences in the forecasts with regard to macroeconomic and price assumptions and supply and demand projections.

\section{Summary}

All of the forecasts were in general agreement on overall economic and energy growth trends for 1993 and 1994. All the forecasts assumed that economic growth, as measured by real gross domestic product (GDP), would accelerate in 1993, having risen moderately in 1992. Differences in macroeconomic assumptions between these forecasts were slight, especially in 1994. Projections for total energy demand growth were also generally consistent with each other, but exhibited somewhat more variation than those of general economic growth. In all of the projections, total energy growth was less than that of real GDP, resulting in continuing declines in energy intensity. All the projections incorporated low inflation rates with little variation between forecasts and only a slight rise in the inflation rate in 1994. Table 8 reveals differences in macroeconomic projections for 1993. Even though EIA uses the DRI macroeconomic model, differences between EIA and DRI projections are due to EIA's inclusion of actual macroeconomic data unavailable to the public at the time of DRI's model release.

All of the projections assumed energy price increases over the 2-year period as a whole, but the projections fluctuated substantially. EIA and DRI projected 1993 crude oil price increases that roughly matched inflation. NERA's average crude oil price for 1993, however, was projected to rise substantially. In contrast, AGA's crude oil price path showed a slight projected dip in 1993; and WEFA's crude oil price projection was virtually unchanged from that of the previous year. As with crude oil, wellhead natural gas price projections in 1993 exhibited variations. EIA and NERA projected sizeable price increases for that year, while the other forecasts showed little year-to-year change. With the exception of DRI, the forecasts projected above-inflation increases in natural gas prices in 1994. Except for AGA, coal price increases were projected to be less than inflation in 1993 and were generally projected to remain virtually unchanged in nominal terms in 1994.

Reflecting modest increases in crude oil prices, domestic crude oil production was projected to decline in 1993 in the forecasts provided by EIA, WEFA, NERA, and IPAA. Only DRI projected a slight, temporary, increase for that year. For 1994, however, NERA projected an increase in production in response to assumed crude oil price increases in both 1993 and 1994. The other four forecasts projected domestic crude oil output declines for 1994. Oil consumption was projected to increase in each of the next 2 years in

\footnotetext{
${ }^{36}$ American Gas Association, 1993 AGA-TERA Base Case, March 1993. DRI/McGraw-Hill, Energy Review, Spring-Summer, 1993. Energy Information Administration, Short-Term Energy Outlook, First Quarter 1993. Independent Petroleum Association of America, IPAA Supply and Demand Committee Long-Run Forecast, 1993-2000, March 1993. National Economic Research Associates, Energy Outlook, February 15, 1993, and April 26, 1993. The WEFA Group, Energy Analysis Quarterly, March 1993.
} 


\begin{tabular}{|c|c|c|c|c|c|c|c|}
\hline \multirow[b]{2}{*}{$\begin{array}{l}\text { Assumptions and Projections } \\
\text { (publication date) }\end{array}$} & \multirow[b]{2}{*}{$\begin{array}{l}\text { History } \\
1992^{\mathrm{a}}\end{array}$} & \multicolumn{6}{|c|}{1993 Projections } \\
\hline & & $\begin{array}{l}\text { EIA } \\
2 / 93\end{array}$ & $\begin{array}{l}\text { DRI } \\
2 / 93\end{array}$ & $\begin{array}{c}\text { WEFA } \\
3 / 93\end{array}$ & $\begin{array}{c}\text { NERA } \\
4 / 93\end{array}$ & $\begin{array}{l}\text { AGA } \\
3 / 93\end{array}$ & $\begin{array}{l}\text { IPAA } \\
3 / 93\end{array}$ \\
\hline \multicolumn{8}{|l|}{ Price Assumptions (nominal) } \\
\hline $\begin{array}{l}\text { World Oil Price (dollars per barrel) . . . . . . . } \\
\text { Petroleum Products (dollars per U.S. gallon) }\end{array}$ & 18.39 & 19.00 & 19.03 & 18.25 & 20.00 & 18.20 & N/A \\
\hline Motor Gasoline (retail) $\ldots \ldots \ldots \ldots$ & 1.19 & 1.21 & 1.23 & 1.21 & N/A & N/A & N/A \\
\hline Heating Oil (retail) & 0.94 & 0.96 & 1.07 & N/A & 1.03 & N/A & N/A \\
\hline Natural Gas Wellhead (dollars per thousand cubic feet) & 1.84 & 1.95 & 1.83 & 1.71 & 1.98 & 1.84 & N/A \\
\hline Coal-utility (dollars per million Btu) $\ldots \ldots \ldots \ldots \ldots$ & 1.41 & 1.42 & 1.37 & 1.49 & N/A & 1.56 & N/A \\
\hline \multicolumn{8}{|l|}{ Macroeconomic Growth Rates } \\
\hline Real GDP (percentage change from previous year) & 2.0 & 2.6 & 3.0 & 3.3 & 3.3 & 3.0 & 3.0 \\
\hline Industrial Index (percentage change from previous year) $\ldots$ & 1.5 & 3.4 & 3.9 & 4.0 & 4.4 & N/A & 3.5 \\
\hline Inflation (percentage change from previous year) $\ldots \ldots \ldots$ & 2.6 & 2.5 & 2.2 & 2.6 & 2.6 & 3.5 & 2.7 \\
\hline Personal Income (percentage change from previous year) .. & 2.1 & 2.6 & 2.2 & 3.0 & N/A & 3.2 & N/A \\
\hline Energy Intensity ${ }^{b} \ldots \ldots \ldots \ldots \ldots \ldots \ldots \ldots$ & 16.69 & 16.67 & 16.05 & 16.57 & N/A & $c_{17.18}$ & 16.56 \\
\hline \multicolumn{8}{|l|}{ Energy Supply } \\
\hline Crude Oil Production (million barrels per day) ${ }^{d}$ & 7.15 & 6.93 & 7.24 & 7.04 & 7.08 & N/A & 6.97 \\
\hline Net Oil Imports (million barrels per day) ${ }^{\theta} \ldots$ & 6.98 & 7.52 & 7.16 & 7.71 & 7.41 & N/A & 7.32 \\
\hline Total Gas Production (trillion cubic feet). & 18.18 & 18.58 & 18.85 & 18.25 & 18.37 & 17.94 & 18.28 \\
\hline Net Gas Imports (trillion cubic feet) & 1.92 & 2.17 & 1.93 & 1.90 & 2.10 & 1.99 & 2.21 \\
\hline Coal Production (million short tons) & 1,007 & 1,019 & 1,002 & 1018 & N/A & N/A & $N / A$ \\
\hline Net Coal Exports (million short tons) & 102 & 104 & 92 & 102 & N/A & N/A & N/A \\
\hline Electricity Generation (billion kilowatthours) . . . . . . . . & 2,797 & 2,876 & 2,905 & 2,834 & N/A & 2,948 & N/A \\
\hline \multicolumn{8}{|l|}{ Energy Demand } \\
\hline Total Oil Products (million barrels per day) $\ldots \ldots \ldots \ldots \ldots$ & 16.98 & 17.30 & 17.16 & 17.36 & ${ }^{t} 16.58$ & 17.52 & 17.19 \\
\hline (percent change from prior year) $)^{9} \ldots \ldots \ldots \ldots \ldots$ & 1.6 & 1.9 & 1.1 & 2.1 & 2.9 & 1.9 & 1.1 \\
\hline Motor Gasoline (million barrels per day) $\ldots \ldots \ldots \ldots \ldots$ & 7.27 & 7.34 & 7.28 & 7.32 & N/A & 7.28 & 7.33 \\
\hline (percent change from prior year) $\ldots \ldots \ldots \ldots \ldots \ldots$ & 1.1 & 1.0 & 0.1 & 0.7 & N/A & 1.6 & 0.8 \\
\hline Jet Fuel (million barrels per day) & 1.46 & 1.48 & 1.45 & 1.50 & N/A & 1.55 & 1.48 \\
\hline (percent change from prior year) & -0.7 & 1.4 & 1.4 & 2.7 & N/A & 2.2 & 1.7 \\
\hline Distillate (million barrels per day). & 3.03 & 3.12 & 3.03 & 3.07 & N/A & 3.27 & 3.06 \\
\hline (percent change from prior year) & 3.8 & 3.0 & 2.4 & 3.1 & N/A & 6.4 & 2.8 \\
\hline Residual (million barrels per day) & 1.08 & 1.13 & 1.12 & 1.15 & N/A & 1.02 & 1.07 \\
\hline (percent change from prior year) ..... & -0.9 & 4.6 & 3.7 & 6.9 & N/A & -11.2 & -1.8 \\
\hline Natural Gas Demand (trillion cubic teet) & 19.71 & 20.38 & 20.33 & 20.12 & 20.42 & 20.47 & 20.15 \\
\hline (percent change from prior year) .... & 3.5 & 3.4 & 3.6 & 2.0 & 3.4 & 2.3 & 2.1 \\
\hline Coal Demand (million short tons) ..... & 893 & 910 & 914 & 912 & N/A & 918 & N/A \\
\hline (percent change from prior year) ... & 0.6 & 1.9 & 1.1 & 0.6 & N/A & 2.7 & N/A \\
\hline Electricity Sales (billion kilowatthours) & 2,755 & 2,834 & 2,829 & 2,863 & N/A & 2,908 & N/A \\
\hline (percent change from prior year). . & -0.1 & 2.9 & 3.8 & 3.6 & N/A & 4.6 & N/A \\
\hline Total Energy Demand (quadrillion Btu) & 82.1 & 84.1 & 84.4 & 84.3 & N/A & ${ }^{c} 87.3$ & 83.9 \\
\hline (percent change from prior year) .... & 1.0 & 2.4 & 2.6 & 2.2 & N/A & 2.8 & 1.9 \\
\hline Oil Import Dependence (percent) & 41.1 & 43.5 & 41.7 & 44.4 & 44.6 & N/A & 42.6 \\
\hline
\end{tabular}

\footnotetext{
${ }^{\theta}$ EIA data.

'Gross energy use per dollar GDP, in thousand Btu per 1987 dollars.

Includes renewables.

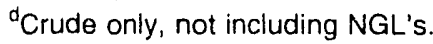

${ }^{\theta}$ Crude oil and products.

${ }^{\dagger}$ Excludes processing gain.

${ }^{9}$ Percentage change calculations are based on 1992 historical estimates of each forecaster, which may differ from those of ElA

Btu = British Thermal Unit.

$\mathrm{N} / \mathrm{A}=$ Not available.

Sources: U.S. Department of Energy, Energy Information Administration, Short-Term Energy Outlook, First Quarter, 1993; DRI/McGraw-Hill, Energy Review, First Quarter 1993; the WEFA Group, Energy Analysis Quarterly, March 1993; National Economic Research Associates, Energy Outlook, February 15, 1993, and April 26, 1993; American Gas Association-TERA Base Case 1993, March 1992; Independent Petroleum Association of America, IPAA Supply and Demand Committee Long-Term Forecast, 1993-2000, March 1993.
} 


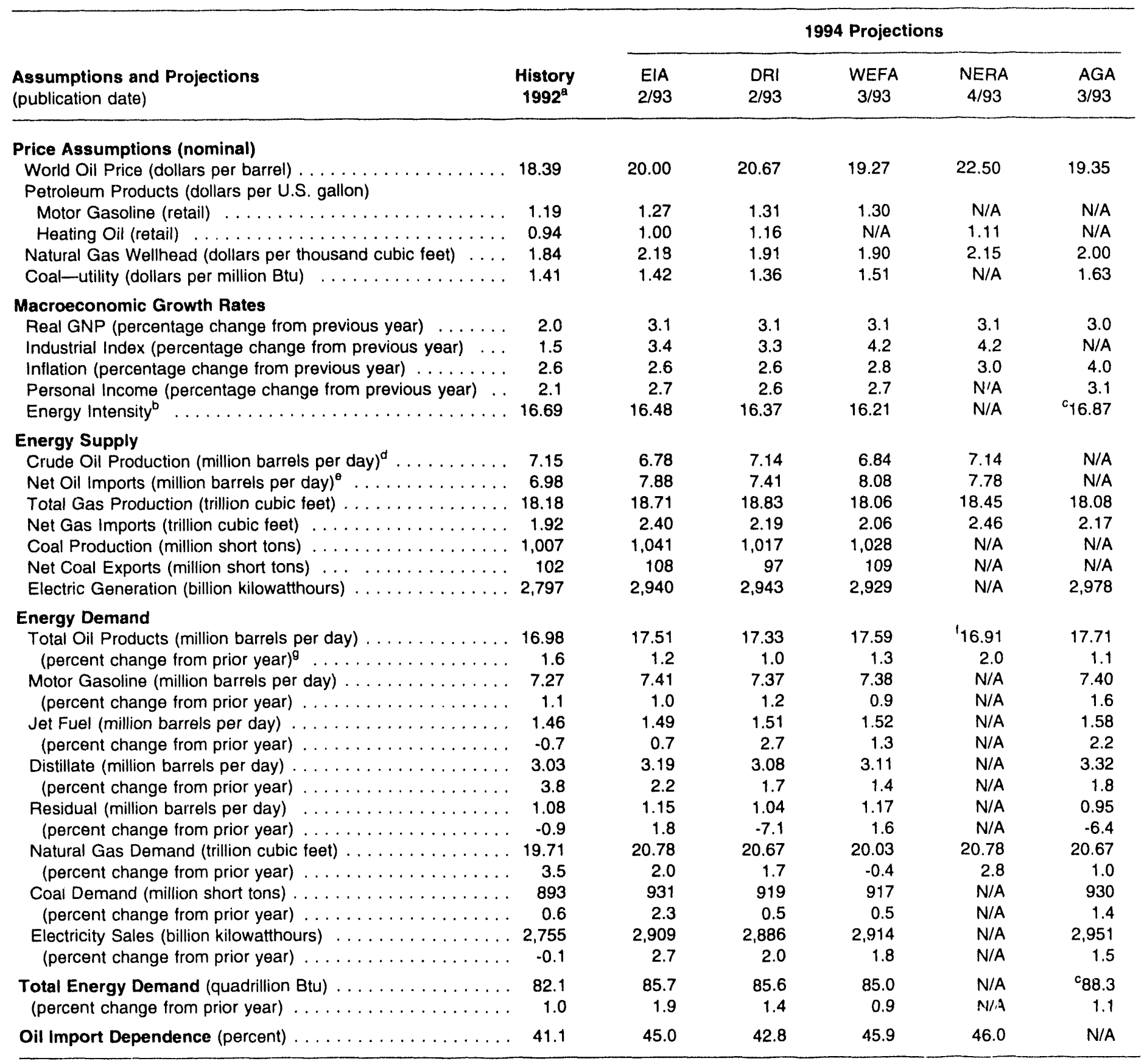

${ }^{a} E I A$ data.

${ }^{\mathrm{B}}$ Gross energy use per dollar GDP, in thousand Btu per 1987 dollars.

cincludes renewables.

${ }^{\circ}$ Crude only, not including NGL's.

${ }^{\theta}$ Crude oil and products.

'Excludes processing gain.

gPercentage change calculations are based on 1992 historical estimates of each forecaster, which may differ from those of ElA.

Btu = British Thermal Unit.

N/A $=$ Not available.

Sources: U.S. Department of Energy, Energy Information Administration, Short-Term Energy Outlook, First Quarter, 1993; DRI/McGraw-Hill, Energy Review, First Quarter 1993; the WEFA Group, Energy Analysis Quarterly, March 1993; National Economic Research Associates, Energy Outlook, February 15, 1993, and April 26, 1993; American Gas Association-TERA Base Case 1993, March 1992; Independent Petroleum Association of America, IPAA Supply and Demand Committee L.ong-Term Forecast, 1993-2000, March 1993. 
all the forecasts, but growth rates varies widely. Substantial differences in residual fuel oil demand growth and differing assumptions about automobile fuel efficiency gains accounted for the bulk of the divergence in petroleum demand patterns. Natural gas production was generally projected to increase in each of the 2 years, except in the WEFA projection, which indicated a slight decline in 1994. Gas consumption in 1993 was expected to increase by rates that exceed those of oil consumption in five of the six forecasts. WEFA projected an increase similar to that of oil consumption. In 1994, however, natural gas consumption in the WEFA forecast was projected to decline slightly due to displacement by residual fuel oil in the industrial sector. The other projections called for increases in natural gas consumption in 1994 at or above those of petroleum. Coal production and consumption were projected to increase in all of the forecasts for both years, but the range of increases was influenced by differences in electricity sales and other fossil fuel prices. Electricity sales and generation were projected to rise in each year in all of the forecasts.

\section{Econorric and Price Assumptions}

Real gross domestic product (GDP) grew by an estimated 2.0 percent in 1992. ${ }^{37}$ All of the projections assumed accelerated growth in 1993, but the EIA projection of 2.6 percent for that year was lower than the other five projections, which ranged from 3.0 to 3.3 percent. For 1994, however, economic growth projections for the five forecasts providing projections for that year were within a narrow range of 3.0 to 3.1 percent. Industrial production was also slated to increase during the forecast interval in all of the scenarios providing such a projection. In 1993, however, EIA's projection of a 3.4-percent growth rate was somewhat lower than the 3.9- to 4.4-percent range projected by DRI, WEFA, and NERA. That difference paralleled the divergence in GDP growth rates. Inflation rates for 1993, as measured by the implicit price deflator, ranged from a low of 2.2 percent for DRI to 3.5 percent for AGA. EIA's projection was 2.5 percent. All of the forecasts assumed for 1994 a modest rise in inflation, ranging from 2.6 percent for EIA and DRI to 4.0 percent for AGA.

World oil prices were projected to increase during the two-year interval from those of 1992, but the forecasts pointed to substantial divergences in 1993. WEFA and
AGA projected year-to-year declines of 14 and 19 cents per barrel, respectively, while EIA, DRI, and NERA projected increases of 61 cents, 64 cents, and $\$ 1.61$ per barrel, respectively. As a result, average crude oil prices for 1993 ranged from a low of $\$ 18.20$ (ACA) to a high of $\$ 20.00$ per barrel (NERA) compared to $\$ 18.39$ in 1992 , with EIA's projection falling in between at $\$ 19.00$. For 1994, all of the forecasts assumed increases in crude oil prices. These increases ranged from $\$ 1.00$ per barrel (EIA) to $\$ 2.50$ per barrel (NERA).

Differences in product price projections partly reflected those of crude oil prices. Motor gasoline prices in 1993 were expected to rise an average of 2 cents per gallon in 1993 for EIA and WEFA, and 4 cents per gallon for DRI, due in part to the modest increases in crude oil prices. In 1994, the year-to-year increase in motor gasoline prices was projected to range from 6 cents (EIA) to 9 cents (WEFA). Differences in heating oil price projections in 1993 reflected differences in the estimates for the 1992 base numbers. For EIA and DRI, year-to-year changes for 1993 were very small. The larger increases projected for 1994-9 cents per gallon for DRI and 8 cents per gallon for NERA-were reflective of the crude-oil price assumptions.

Natural gas price changes in the forecasts showed significant variation in 1993, ranging from a projected decline of 13 cents per thousand cubic feet (WEFA) to an increase of 14 cents per thousand cubic feet (NERA). All of the projections for 1994, however, assumed increases in natural gas prices, ranging from 8 cents per thousand cubic feet (DRI) to 2.3 cents per million cubic feet (EIA). Although the relationship between oil and gas prices is not very tight, NERA's projection of $\$ 2.15$ per thousand cubic fect-the highest 1994 forecast-partly reflected a projected crude oil price of $\$ 22.50$ per barrel, the second highest of the crude oil price projections for that year. WEFA's wellhead gas price forecast of $\$ 1.90$ - the lowest for 1994-was partly indicative of the $\$ 19.27$-per-barrel oil price projection, the lowest of the forecasts.

\section{Primary Energy Supply}

U.S. crude oil production was expected to decline in four of the five projections in 1993. The projections ranged from a decline of 220,000 barrels per day (EIA) to an increase of $110,0(0)(\mathrm{DR}) .{ }^{36}$ In 1994 , changes in oil production ranged from a decline of $200,(0)(0)$ barrels

\footnotetext{
${ }^{37}$ Based on tabulations of 1991 data reports by the Office of Energy Markets and find Use.

"Based on DRI's 1992 production estimates.
} 
per day (WEFA) to an increase of 60,000 barrels per day (NERA). ElA projected a decline of 150,000 barrels per day. NERA's production increase in 1994 reflected the lagged response to the large oil price increases of 1993 and 1994. WEFA's substantial decline reflected the previous year's decline in oil prices as well as the lack of response to the subsequent incipient recovery in those prices.

For all the forecasts, a strengthening economy and the resumption of the decline in domestic crude oil production resulted in increased U.S. net oil imports for both forecast years, but these projections differed substantially. For 1993, the projections ranged from 7.16 million barrels per day (DRI) to 7.71 million barrels per day (WEFA). EIA projected 7.52 million barrels per day. DRI's low projection stemmed largely from the increase in production postulated for that year; WEFA's robust projection, however, reflected the combination of substantial price-induced heavy fuel oil demand growth, as well as a sizeable decline in domestic oil production. For 1994, WEFA's net import projection grew to 8.08 million barrels per day, while DRI's net import projection of 7.41 million barrels per day again represented the lowest of the forecasts. EIA projected net imports of 7.88 million barrels per day. These results also complemented diffe.ences in oil production decline forecasts

Natural gas production projections for 1093 showed increases from 1992 estimates in all six of the surveyed forecasts, ranging from (0.33 trillion cubic feet (WEFA) to 0.84 trillion cubic feet (DRI)." (It should be noted that because 1992 estimates of notural gas production differ with each forecast, the individual projections for 1993 cannot be compared to the ELA estimate for 1992 in deriving vear-to-year changes.) EIA forecasted an increase of 0.40 trillion cubic feet. 1994 forecasts of preduction ranged from a decline of 0.19 trillion cubic feet (WEFA) to an increase of 0.14 trillion cubic feet (ACA ). ElA's increase of 0.13 billion cubie feet was similar to that of $\mathrm{AC} A$. Differences in natural gas price projections and the relative price of natural gas to residual fuel oil accounted for much of the divergence in natural gas production projections over the forecast intersal. The average 1993 gas price in the WEPA forecast (\$1.71 per thousand cubic feet) was the lowest of the five projections, minimising the increase in production. The highest projection-31.95 perthousond cubic teet (E:LA) was associated with the sizeable increase in production in that prejection. The projected decline in WEFA's production forecast was brought about by a decline in industrial gas consumption for that year because of a shift in the relative price of gas favoring heavy fuel oil. Conversely, the large increase in the ACAA's gas production stemmed from a projected price-induced shift away from residual fued oil in the industrial sector.

Coal production in all forecasts was expected to increase in 1993 from their respective 1992 estimated levels, and are projected to sustain increase's in 1994 as well. DRI expected coal exports to decline temporarily in 1993 as a result of weakening economies in both Europe and Asia. WEFA, on the other hand, projected continuing increases in coal exports throughout the forecast period on the assumption that growth in Asian economies would offset weakness in European coal demand.

\section{Energy Demand}

All of the forecasts projected growth in petroleum demand for both 1993 and 1994 , reflecting conomic growth substantially above that of $19(9) 2$. For 1993 , increases in consumption from 1992 levels ranged from II'AA's 180,000 barrels per day, a 1.1-percent increase, to NERA's 470,000) barrels per day, a 2.9-percent increase." This spectrum of oil projected growth rates occurred despite all the forecasts assuming similar economic and industrial production growth raten for the year. The ElA's increase of $32(0,() 0)$ harrels per day, a 1.9 -percent increase over 1992, represented the middle. of that range. For 1964, however, the speetrum of petroleum products demand projections was somewhat narrower, suggesting a tighter relationship between demand growth and economic groweth. DRI agrain projected the lowest growth in petroleum products demand-170),0(0) barrels per didy, or 1.0 percent. NERA's 330,000 barrel-per-day growth, a 2.(1-percent increase, was the highest. NERA contended that the robust growth in petroleum products demand in both years would be more strongly related to that of the economy than did the other projections. EIA projected growth in demand of $210,(0)(0)$ barrels per day, or 1.2 percent.

Projections of demand for the various petroleum products were generally mixed for both forecast years. For example, DRI's conservative growth projections tor overall petroleum products demand in 199,3 stemmed

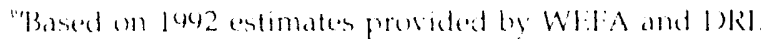

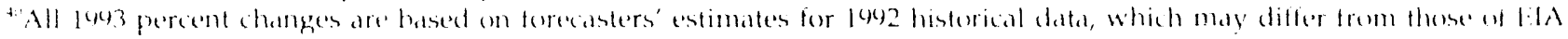


from the assumption that motor gasoline growth would be flat due to continued high efficiency growth rates. The other forecasts assumed a continuing slowdown in fleet fuel efficiency gains as a result of flat or slightly declining efficiency gains in new vehicles.

Although AGA's total petroleum products demand growth for 1993 was 1.9 percent, the same as EIA's, their procedures for projections for individual product demand growth were substantially different from each other. AGA projected a 6.4-percent increase in distillate clemand and a decline of 11.2 percent in residual fuel oil consumption, the only negative growth projection for any product by any of the forecasters for 1993. In that projection, coal demand was projected to displace significant amounts of fuel oil, and even some gas, in the generation of electricity. For 1994, DRI forecast motor gasoline growth to be 1.2 percent, similar to the other projections. Residual fuel oil demand, however, was projected to slide by more than 7 percent, contributing to the continued slow growth in overall petroleum demand.

Similarly, in 1994, AGA projected a 6.4-percent drop in year-to-year residual fuel oil consumption, offsetting some of the increase in demand for other petroleum products. For 1994, AGA projected that electricity demand grow th would slow to 1.5 percent, accounting for much of the continued erosion of heavy fuel oil demand, as well as for the slowdown in the growth of both natural gas and coal demand.
Expectations of natural gas and coal consumption reflected varying assumptions about the competitive iature of fossil fuels to the utility and industrial sectors. WEFA's 1993 projections of a 2.()-percent increase for natural gas demand and only a 0.6-percent rise in coal demand were the lowest of the forecasters for each of those fuels, despite WEFA's forecasts of robust economic and electricity sales growth. Continued weakness in oil prices resulted in a projection of a substantial recovery in heavy fuel oil sales at the expense of both gas and coal.

In 1993, the AGA forecast, coal demand was projected to increase 2.7 percent, the highest projection for that product. This accounted for the bulk of the displacement of residual fuel oil. The EIA projected the highest growth rates for both natural gas ( 2.0 percent) and coal consumption ( 2.3 percent) for 1994 without any compensating erosion in heavy fuel oil demand, which was projected to grow at 1.8 percent.

EIA's 1994 electricity sales growth projection of 2.7 percent, which was also higher than the other forecasters, was sufficient to support the growth in demand for these fuels. The lowest rate of electricity growth for 1994 was AGA's 1.5 percent, contributing to the slide in residuai fuel oil demand and the slowdown in the rate of natural gas demand for the year. 


\section{Forecast Evaluation}

This chapter presents an evaluation of total forecast errors for selected major energy variables: energy prices, macroeconomic variables, weather, demand, and production for petroleum, natural gas, coal, and electricity as published in the third quarter 1991 through the fourth quarter 1992 issues of the Short-Term Energy Outlook (Outlook). ${ }^{41}$ Detailed forecast error tables for selected variables are presented in Appendix A. This chapter continues a long tradition of presenting a discussion of average quarterly Outlook total forecast errors. In Chapter 5 the first installment of a more indepth assessment of forecast errors is presented.

\section{Summary Error Analysis}

Table 10 presents a summary of the average absolute errors for the forecasts published in the third quarter 1991 through the fourth quarter 1992 issues of the Outlook, as well as the average absolute errors published in the previous issue of the Supplement (covering the third quarter 1990 through the fourth quarter 1991 issues of the Outlook). Table 10 shows that, in percentage terms, most forecasts generally improved over the forecasts examined in the 1992 Supplement. With the exception of "other" petroleum products and end-of-the month petroleum stocks, all of the selected petroleum variables showed improvement. There were also improvements for coal, natural gas demand, and electricity generation from coal, natural gas, and nuclear power. Price forecasts, with the exception of coal to electric utilities, also improved. Several products benefitted from offsetting errors in the underlying assumptions. Natural gas demand was affected because of abnormally low heating degreedays, but was buoyed by lower prices, particularly in the first quarter of 1992, resulting in generally better forecast accuracy. Because of the smaller forecasting errors for prices and industrial production, most forecasts improved. Over the last six issues of the
Outlook, the forecasts for electricity prices, motor gasoline demand, total crude oil production, and industrial electricity sales had the smallest eriors; residual fuel oil prices, natural gas wellhead prices, petroleum and hydroelectric generation had the largest errors.

The summary forecast evaluation table presents the absolute average percent error of 21 quarterly forecasts made in six Outlooks, from the third quarter 1991 through the fourth quarter 1992. The forecast evaluation tables present the average absolute errors in physical units in the upper half of the table, and percent errors in the lower half. For Tables A1 through A36, the average absolute error by quarter (the last row on the bottom of each portion of the table) is calculated from top to bottom, by taking the mean of the absolute values of the differences between the actual and forecasted values for each quarter of the report. The average absolute error by report (the last column on the right-hand-side) is calculated horizontally across the table, by taking the mean of the absolute values of the differences between the actual value and the forecasted values for each quarter across reports. The overall error (shown in the bottom right-hand corner in both the upper portion (physical units) and lower portion (percent) for each table) is the mean of all of the absolute errors in the table.

\section{Prices}

\section{Refiner Acquisition Cost of Imported Crude Oil}

Prices, particularly the refiner acquisition cost (RAC) of imported crude oil, are important driving forces for many of the forecasts published in the Outlook. Errors in forecasting the RAC, while obviously having an adverse effect on the results for petroleum product

\footnotetext{
"Generally, three forecasts, based on three different scenarios for world oil prices, are presented in each Outlook. Only the base or "mid" case scenario is evaluated in this analysis.
} 
Average Absolute Percent Error

Variable

\begin{tabular}{cc}
\hline & 6 Quarters \\
6 Quarters & 3Q90-4Q91 \\
3Q91-4Q92 & 1992 Supplement \\
\hline
\end{tabular}

Oil Price and Macroeconomic Projections

Refiner Acquisition Cost of Imported Crude Oil . . . . . . . . . . .

Real Personal Disposable Income . . . . . . . . . . . . . . . . .

\section{Prices}

Motor Gasoline . . . . . . . . . . . . . . . . . . . . . . . . . . . . . 3.2

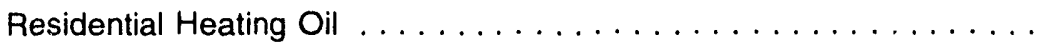

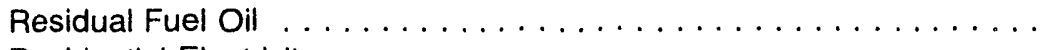

Residential Electricity . . . . . . . . . . . . . . . .

Wellhead Natural Gas . . . . . . . . . . . . . . . . . . . . . . . . 14.2

Residential Natural Gas $\ldots \ldots \ldots \ldots \ldots \ldots \ldots \ldots \ldots$

\section{Petroleum}

Total Petroleum Demand . . . . . . . . . . . . . . . . . . . . . . 1.4

Motor Gasoline Demand . . . . . . . . . . . . . . . . . . . .

Distillate Fuel Oil Demand . . . . . . . . . . . . . . . . .

Residual Fuel Oil Demand . . . . . . . . . . . . . . . . .

Jet Fuel Demand. . . . . . . . . . . . . . . . . . . . .

Other Petroleum Products Demand $\ldots \ldots \ldots \ldots \ldots \ldots \ldots \ldots$

Total Domestic Crude Oil Production . . . . . . . . . . . . .

Alaska Crude Oil Production. ... . . . . . . . . . . . . . .

Lower 48 Crude Oil Production. . . . . . . . . . . . . . . .

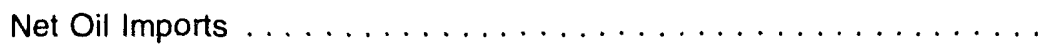

\section{Natural Gas}

Natural Gas Consumption . . . . . . . . . . . . . . . . .

Natural Gas Production . . . . . . . . . . . . . . . . . .

Coal

Domestic Coal Consumption .......................

\section{Electricity}

Total Electricity Sales $\ldots \ldots \ldots \ldots \ldots \ldots \ldots \ldots \ldots \ldots$

Residential Electricity Sales . . . . . . . . . . . . . . . .

Commercial Electricity Sales $\ldots \ldots \ldots \ldots \ldots \ldots \ldots \ldots \ldots$

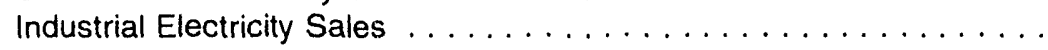
Generation by Fuel

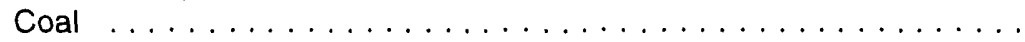

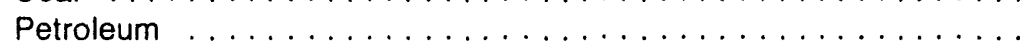

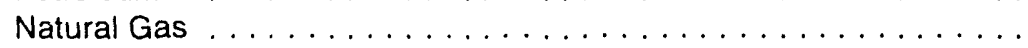

Nuclear Power ...........................

Hydroelectric Power 
prices, also affect the results of natural gas prices, as well as petroleum and natural gas demand and production. Based on the mid-oil price case forecasts, the overall average absolute error for the RAC was 8.2 percent or about $\$ 1.50$ per barrel, over the last six issues of the Outlook. This compares with a previously reported error of 26.4 percent in the 1992 Supplement (Tables 10 and A1). With the exception of the first and second quarter Outlooks, most of the reports overstated the forecasts, not anticipating the price drops of RAC, due to oversupply, particularly in both winter quarters of 1492 .

\section{Petroleum Product Prices}

Retail motor gasoline price torecasts had an average absolute error of 3.2 percent or about 4 cents per gallon, a large improvement over the 9.8 percent reported in the prevolous Supplement (Tables 10 and A2). Almost all of the motor gasoline price forecast errors, which were generaliy higher than expected. can be attributed to the werestimations of RAC prices, a major component of gas bline prices.

The residential raating oil price forecasts had an average absol.zic error of 7.1 percent over the last six Oulwh compared to 15.3 percent in the previous supplement 'Table A3). The largest errors occurred in the winter quarters of 1942. Unusualiy warm weather in the first quarter of 1992 and low world oil prices in the first and last quarters of 1992 were the main reasons fir these forecast errors (Tables $A 11$ and $A 1$ ).

Resdual fued oil price forerdsts had an average absolute error of 16.2 percent, over the last six Oullooks (Table At). This was a significant improvement for this whatile fue! price over the 45.2 percent crror reported in the provious supplement. In addition to the crude oil price overestimations. a weak economy in 1991 and a mild winter in the first quarte of 1992 also led to excess natiral gas supply, and thus low natural gas prices. This, ir turn, resulted in an oversupply of residual fuel oil and thus a fall in price, compounding the forecast errors.

\section{Natural Gas}

Forecast errors for natural gas wellhead prices have areraged 14.2 percent over the last vear and a half (Table A5). The forecasts made in the tirst quarter 1992 werstated gas prices by not anticipating the collapse of these prices due to the mild $n$ inter. This left relatively high underground storage levels, which put further downward pressure on prices." On the other hand, the forecasts were understated for the last 3 quarters of 1992 due to the cold spring, the production slowdown and expectation of further delivery problems caused by Hurricane Andrew in August 1992, and due to low storage levels in the latter part of the year, which led to higher-than-anticipated prices.

Residential natural gas price forecast errors were relatively small, averaging just 2.4 percent (Table A6) compared to 4.7 percent in the previous Supplement). The wellhead price is a small portion of the residential price, while distribution costs account for most of the differences in the cost of these fuels. In many instances, the forecasts overestimated the price, with most of the errors due to overestimations of weilhead prices. Again, the warm first quarter winter weather, which redured demand, was a large cause of the errors.

\section{Residential Electricity}

Residential electricity price forecasts, with a 0.8 -percent error rate, or 0.06 cents per kilowatthour, have been the most accurate of all the energy forecasts evaluated in the Supplement (Table A7). Ten of the 21 forecast quarters reported in Table A7 had forecasts exactly equal to the actual data. It should be noted though, that the electric u(ilities industry is highly regulated and the end-use prices of this industry have been quite stable over the last several years.

\section{Electric Utility Coal Prices}

Projections for coal prices to electric utilities have averaged a 3.3-percent error rate (Table A8). Due to unanticipated but dramatic increases in mining productivity, these utility coal prices have been trending downward over the last several years, while other fuel prices to electric utilities have fluctuated up and down. The forecasts have consistently overstated prices, but by a relatively small amount. Future forecasts for coal prices in the Oullook will incorporate a greater emphasis on mining productivity gains, and the effects of these on coal production costs

\section{Economic Activity Indicators and Weather}

The demand for energy is highly correlated with the level of economic activity. The major economic drivers

-Eners Information Administration, Monthin Energy Rouew, DOE/EIA-\$035(93/01), Table 44. 
in the short-term forecasting models are the industrial production index for manufacturing and real disposable personal income. The economic forecast is developed using EIA's world oil price and other energy price assumptions to solve the DRI/MCCraw-Hill (DRI) Quarterly Model of the LIS. Economy. Therefore, the ElA economic forecasts represent DRJ's forecasts, except for adjustments for the different energy price assumptions.

The actual numbers for real disposable personal income are based on the Department of Commerce's National Income and Product Accounts (NIPA). In December 1991, the Department of Commerce rebased the NIPA from 1982 constant dollars to 1987 dollars. " Changing the underlying base period for the calculation of constant dollar estimates and the associated price indexes involved a more comprehensive revision of the national income and product accounts. The revision to 1987 dollars of the NIPA meant that the weights used to calculate aggregate prices in the base period changed, reflecting the 1987 consumption and production mix. In addition. the Department of Commerce used updated source data and revised estimating procedures in order to calculate the national accounts. The Department of Commerce incorporates these comprehensive revisions every 5-7 years, with the last one released in 1985. Of the six Outlooks evaluated in this supplement, the third quarter 1991 through the first quarter 1992 issues of the (Outlook used 1982 constant dollars. For evaluation purposes, the income forecasts for whose reports were rebased from 1482 to 1487 constant dollars. However, precisc comparisons between actual and forecasted national account data for that period cannot be made due to the rebasing of the weights. Thus, the forecast evaluation table for real disposable personal income (Table $A^{4}$ ) is not a true measure of forecast accuracy.

\section{The Industrial Production Index for Manufacturing}

The industrial production index for manufacturing had an average absolute error of 1.4 percent over the six most recent forecast quarters (Table $A 10)$. Most of the errors were overestimations, since the forecasts were overly optimistic about the economy. In fact, manufacturing growth was somewhat sluggish during this period. ${ }^{+4}$ These overestimations tended to lead to overstatements of energy demands in the forecasts. The effects and the length of the recent recession on industrial production were not fully reflected in the forecasts made, especially in 1991.

\section{Weather}

Weather has been a key variable, affecting the whole range of energy products, including demand, stock levels, imports, production, and prices. The projections for the various energy variables in the Outlook assume "normal" weather in the forecast period. "Normal" is defined as a 30-year average of the heating (or cooling) degree-days. The last several winters have been considerably milder than the 30-year (1951-1980) average used by the National Occanographic and Atmospheric Administration. The first quarter 1992, for example, was nearly 11 percent warmer than normal (Table A11). Therefore, projections for heating fuels, particularly distillate and residual fuels were somewhat overstated. Deviations from normal for cooling degreedays are most likely to affect electricity sales in the third quarter (the peak cooling season when air conditioning is most used). The summer of 1992 was about 13.5 percent cooler than normal (Table A12) and thus, residential and commercial electricity sales forecasts were overestimated.

\section{Petroleum}

\section{Demand}

For the six Short-Term Energy Outlooks, the average absolute forecasting error for petroleum demand was 1.4 percent or $240,(0) 0$ barrels per day (Table A13), compared to 2.0 percent in the previous Supplement. For the major petroleum products, the average absolute error ranged from 1.0 percent for motor gasoline, to 5.7 percent for residual fuel oil.

Motor gasoline forecast errors averaged a low 1.0 percent (or 70,000 barrels per day) compared to 1.4 percent in the previous Supplement (Tables 10 and A14). Most of the forecast errors, albeit small, tended to understate gasoline demand. Motor gasoline demand grew between 1991 and 1992, while the forecasts tended

\footnotetext{
"For a complete die usuen of the NIPA resiston to lakz constant dollars, see "A Preview of the Comprehensive Revision of the National

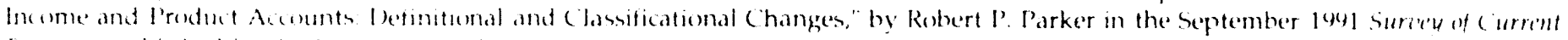
Bumbers publoshed by the lepartment of commerce

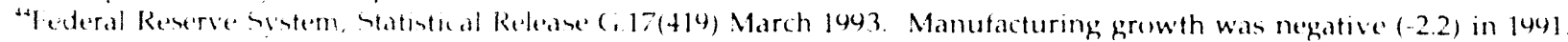


to project zero growth over that period. This was due to the assumption that efficiency gains (average miles per gallon) would offset increases in fleet size and vehicle-miles traveled.

The first quarter 1992 winter weather, which was much milder than the historical average, contributed to large forecasting errors in projections of demand for some products (Table A11). As a consequence of two consecutively mild winters, distillate fuel demand fell a substantial 9.4 percent below average predictions for the first quarter of 1992 . However, the average absolute percent error for this fuel was 4.3 percent (Table A15), a slight improvement over the 4.8 percent error reported in the previous Supplement. Residual fuel oil forecast errors averaged 5.7 percent, or more than half the 10.7 percent-average error in the previous Supplement (Table A16). Third quarter 1992 forecasts averaged 11.4 percent higher than actual demand, primarily because cooling degree-days turned out to be more than 13 percent below normal, thus reducing electric utility peak demand for this fuel (Table A12).

Forecasts of demand for "other" petroleum products (motor gasoline blending components, asphalt, road oil, petroleum coke, LPG, waxes, lubricants, unfinished oils, aviation gasoline blending components, and miscellaneous oils) worsened compared to the previous Supplement. The average absolute forecasting error for "other" petroleum products supplied was 4.8 percent, or 200,000 barrels per day (Table A18), compared to 1.9 percent in the previous report. All the forecasts for 1992 understated demand; in some instances by as much as 10 percent. These large underpredictions were the consequence of cumulative underpredictions of the various fuels that make up the "other" category. An unexpected domestic oversupply of petroleum coke resulted from a 4.9-percent increase in refinery output of coke (to record levels), coupled with an 8.1-percent decline in coke exports caused by the recession in Western Europe. ${ }^{45}$

Motor gasoline blending component demand also increased dramatically in 1992 over 1991 levels. Beginning with the March 1993 Petroleum Supply Monthly, motor gasoline blending components demand (product supplied) will be reported as finished motor gasoline product.

Jet fuel demand forecasts also improved, with an average error of 3.1 percent, or 50,000 barrels per day, compared to an average error of 4.2 percent in the previous report (Table A17). For 1992, most of the forecasts tended to overstate demand, not anticipating the slow growth in income and the continued economic troubles in the a rline industry.

\section{Domestic Crude Oil Production}

The forecasts of crude oil production were among the most accurate of the forecasts with an average error of 0.8 percent or 60,000 barrels per day (Table A19). In the Outlook, domestic crude oil production is divided into two categories: Alaskan production, which comprises about 25 percent of domestic production, and Lower 48 production, which comprises the remaining 75 percent. Although most of the forecast errors of each of the production categories were in the same direction, there were 8 of 21 forecast quarters where the errors had opposite signs. This yielded offsetting errors for total domestic production, which as an aggregate, had an average absolute percent error smaller than either of its two components (Tables A19, A20, and A21).

\section{Total Petroleum Net Imports, Excluding SPR}

Forecast accuracy for net oil imports gained considerably compared to the last Supplement, with an average absolute error of 5.2 percent versus 9.6 percent (Table A22). Errors in the projections of net petroleum imports reflect combined errors in predicting crude oil production and demand, which can sometimes be reinforcing. Overestimation of demand and underestimation of production for a particular quarter is an example of this. The forecast errors for the first quarter of 1992 were the largest, averaging 12.8 percent. In that quarter, U.S demand was low, due in part to the recession. However, production turned out to be higher than anticipated.

\section{Stocks}

The forecasts for petroleum inventories in the Outlook are made under the basic assumption that stocks will move from initial conditions toward "normal" or average seasonal levels, where normal levels are defined as the mean monthly levels observed over the three most recent historical years. Except for the third quarter of 1991, the forecasts were all overestimations. The average absolute error, however, was a relatively

\footnotetext{
"Tetrole'um Supplu Anmual 1991, Volume 1, DOE/EIA-0340(91)/1, Table 4. Petrole'um Supply Annual 1991, Volume 1, DOE:/EIA-(0340(92)/1, Table 4
} 
small 2.6 percent. The largest forecast errors occurred in the fourth quarter of 1992, where the error averaged 4.9 percent. This was due primarily to higher than expected petroleum demand, which led to larger-thannormal crude oil stock draws.

\section{Natural Gas}

\section{Natural Gas Demand}

The average absolute error for the total natural gas demand forecasts done since the third quarter 1991 was under 2.7 percent (Table A24). This was an improvement over the 4.0 error reported in the previous Supplement. The volatile natural gas prices (Table 5) had little effect on the demand forecasts, except in the third quarter of 1991, where extremely low actual prices contributed to an overstatement of demand by 7 percent.

\section{Natural Gas Production}

The natural gas production forecasts errors have been relatively small and consistent over the last several years. The average forecast error was 2.1 percent versus 2.0 percent in the previous Supplement (Table A25). However, forecasts made in the third and fourth quarter 1992 Outlooks tended to overestimate production by an average of over 5 percent. Underground storage withdrawals for the fourth quarter of 1992 were higher than forecasted, thus reducing the amount of natural gas production that was needed to meet expected demand. ${ }^{\text {th }}$

\section{Coal}

The total domestic coal demand forecast is a combination of forecasts of the three major consuming sectors: the coking (metallurgical) coal sector, the electric utilities sector, and the retail and general industry demand sector. Approximately 87 percent of domestic coal is consumed for the generation of electricity; errors in forecasting total electricity generation and sales explain a large part of the error in the total coal forecast. ${ }^{47}$
The average absolute error for total domestic coal demand decreased to 1.9 percent, or 4 million tons, from the 2.6 percent reported in the previous Supplement. All six forecasts for the fourth quarter of 1992 overstated coal demand, albeit, by an average of just 1.4 percent. This was principally the consequence of lower-than-expected electricity sales for that period.

The total coal production forecast is created by summing the forecasts for anthracite coal production and all other coal (bituminous, subbituminous, and lignite) production. Anthracite generally accounts for less than 1.0 percent of total production. ${ }^{48}$

The average absolute error for total coal production was 2.7 percent (Table A27). This is an improvement over the 3.2 percent in the previous Supplement. Production was overestimated for the last 6 months of 1992, primarily because of the lower-than-expected demand for coal at electric utilities.

\section{Electric Utilities}

The average forecast error for total electricity sales was 2.2 percent compared to 1.5 in the previous report (Table A28). This was one of the few forecasts in the Outlook whose accuracy did not improve since the last Supplement. With the exception of the third quarter of 1991, all of the forecasts overstated sales.

The two primary factors that influence electricity sales are the economy and the weather. Of these two, the most important and yet least predictable influence on short-term electricity sales is the weather. The principal reasons for the forecast errors were milder-than-normal weather and a weaker economy than expected. The weather (in terms of heating and cooling degree-days) for purposes of the forecasts, is assumed to be normal. (See section on weather, p. 24). The actual occurrence of normal weather conditions rarely happens for any given quarter and, as a result, heating or cooling requirements are often different than projected.

Residential electricity sales (Table A29) were overestimated by an average of 8.2 percent in the first quarter of 1992 because heating degree-days were 12 percent below normal during that period. Commercial

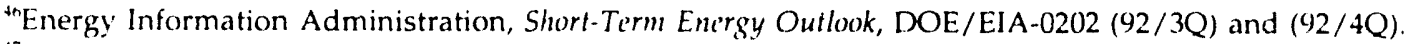

${ }^{4}$ Monthly Energy Review, DOE/EIA-0035(93)/05, Table 6.2. For the years 1990-1992, coal consumption at electric utilities averaged 87 percent of total consumption.

${ }^{44}$ Energy Information Administration, Coal Production 1991, DOE/EIA-0118(91), Table 1.
} 
electricity sales, which are also weather-related, but to a lesser degree, were overstated by an average of 5 percent during the same period (Table A30). Industrial electricity sales, which are not very sensitive to weather, had an average forecast error of only 0.7 percent for that same period (Table A31).

The accuracy of the electricity sales forecast determines the accuracy of electricity generation by fuel source. Thus, if sales are overestimated, so obviously is total generation. Coal generation is tied to this total and to forecasts for nuclear and hydroelectric power. These two latter sources are determined independently. There was a moderate amount of overestimation in coal generation (Table A32) that was caused by underestimation of nuclear power (Table A35).

Electricity generation from petroleum (primarily residual fuel oil) had a an average error of 27.5 percent (Table A33). This rather high error was caused by the overstatement of forecasts for total electricity sales. Since the petroleum share of total generation is by far the smallest of the principal electricity generation sources, a relatively high percent error is expected as a result of errors in total demand, especially if peak demands are reduced with mild weather.

Electricity generation from natural gas had an error rate of 4.9 percent (Table A34). Forecasts for the fourth quarter of 1992 had a relatively high error rate of 10.2 percent. This was the result of the overestimation of total electricity sales and the underestimation of natural gas prices, which had increased rapidly in that quarter, particularly compared to the price of its competing fuel, residual fuel oil (Tables $\mathrm{A} 30, \mathrm{~A} 4$, and $\mathrm{A} 7$ ).

Nuclear generation was projected by determining the nuclear capacity operating during a period and applying an estimated average utilization rate. In recent quarters, the actual utilization rate for nuclear power has been higher than previously forecast. This capacity factor was derived by examining its historical trend. However, in 1991 and 1992, the capacity factor has increased by a larger amount than had been previously forecasted. This has resulted in underestimations of nuclear power generation for most of the forecast quarters. This is very evident in the third and fourth quarters of 1991 when nuclear generation forecasts were underestimated by an average of over 7 percent, while the forecasts for coal generation were overestimated by 2.8 percent (Tables $\mathrm{A} 35$ and $\mathrm{A} 32$ ).

Hydroelectric power was consistently overestimated throughout the forecast periods because some areas of the country, especially the Northwest, which contains the majority of U.S. hydroelectric capacity, experienced below-normal precipitation, while the forecast assumed normal precipitation (Table A36). 


\section{Forecast Error Benchmarks for the Short-Term Integrated Forecasting System}

\section{Introduction}

In order to establish a more systematic analysis of the track record and the model performance characteristics of STIFS, benchmark forecast error decompositions and forecast standard errors that can be regularly updated and compared to those derived from any future versions of the model are provided. This chapter will provide the motivation for the error decompositions and the forecast standard errors and will present an initial set of benchmark statistics for future comparison. Illustrative forecast confidence bands will be presented that can be extended to many key forecasts from STIFS in future reports.

The forecast error decompositions are based on the comparison of a particular model forecast solution to actual endogenous variable realizations, where exogenous forecast inputs are derived from base case assumptions. Thus, the benchmark decompositions are based on comparisons of the base case (or mid price) forecasts for the fourth quarter 1992 Short-Term Energy Outlook (Outlook), and actual model variable observations subsequently recorded, in conjunction with a resimulation of the model with the same initial conditions as the fourth quarter 1992 Outlook, but with corrected exogenous inputs subsequently observed.

The benchmark forecast standard errors are derived from stochastic simulation of the STIFS model using the second quarter 1993 Outlook database. The stochastic simulation runs involved simultaneously perturbing model parameters and equation errors in a Monte Carlo experiment, where the distributions from which the perturbations were drawn were assumed to be normal, with covariances taken from the equation error and parameter covariance matrices calculated in the model estimation process. An extension of the model to account for uncertainty in the inputs which are, for standard model forecasts, taken as exogenous to the model was required for the derivation of forecast standard errors. This model extension is discussed below and in Appendix B.

\section{Error Decompositions}

\section{Background}

In Chapter 4 presents total forecast errors (on a quarterly basis) in order to provide the reader with a general sense of where published Outlook forecasts erred and some general explanation of the factors suspected of causing the errors. There are 4 general reasons why a particular forecast proves to be wrong:

1. Exogenous forecast assumptions or inputs are out incorrect.

2. Data measurement error is discovered (some of the historical data for model variables is revised or corrected, for example).

3. The model is not "accurately specified."

4. Residual uncertainty exists even for a model that is "accurately specified."

The first Reason relates to such factors as the economy not growing as quickly as assumed in the forecast, weather not turning out to be as assumed (the base case assumption always being that weather is "normal"), or crude oil prices that are higher or lower than expected or assumed. It is hoped that errors in exogenous assumptions will explain overall forecast errors when post mortems are done. To isolate this component of the forecast error, the model used to produce a forecast is rerun with everything the same except that exogenous forecasts are replaced with actual values.

The second Reason--data measurement error is discovered--can affect initial conditions for a particular forecast which, because of certain dynamic elements in the model structure, can strongly influence near-term parts of the forecast. One type of data revision that requires attention even before resimulations are performed to isolate exogenous forecast errors 
(reason 1) is a revision which changes the units or index basis of a model variable. Production or inflation indexes, for example, are periodically rebased to a new year or other period. No resimulation can proceed until any revisions such as these are incorporated by rescaling the revised series to the old basis or by model reestimation. Sometimes, data revisions (even those not involving rebasing or units redefinition) are extensive enough that they would have affected the results of model estimation. The latter problem is not usually expected to be a significant one, but it can be treated by reestimation with revised data. Thus, to isolate any effects from data errors (Reason 2), the fourth quarter 1992 version of STIFS was reestimated and the forecast was redone with revised data.

The third Reason for forecast errors--the model is not accurately specified--is not easily isolated, especially for any particular forecast. For the error decompositions, any specification inadequacies are lumped in with residual model error, alluded to in Reason 4 . This specification issue, however, is interesting for another reason. An "accurate" specification is one which, in comparison to all possible alternatives, yields minimum forecast error variance. It is not feasible to consider all possible alternative models for forecasting the variables encompassed by STIFS. However, this definition of accuracy is useful for evaluating future enhancements or changes to STIFS with respect to the effect on forecast error variances relative to an established benchmark.

If a model change increases forecast error variance relative to the benchmark, then the enhancement results in a less accurate model. Thus, a relative cost (or benefit) measure in terms of the impact on forecast accuracy is established for model changes. Some model changes may have unambiguous overall effects on forecast accuracy while others may not. For example, the model change may reduce the forecast error variance for some variables but increase it for others. This contrasts with an unambiguous improvement case in which no forecast error variances are increased while some are reduced. The ambiguous cases will remain absent the formulation of some (ultimately subjective) loss function or weighting scheme among error variances.

\section{Formal Description}

Three components of the forecast errors detected ex post are computed for any variable $Y$ :

$$
E_{Y, T, t}=E_{Y, \lambda, 1}+E_{Y, v, 1}+E_{Y, r, 1}
$$

where:

$$
\begin{aligned}
& E_{Y, T, t}=\text { total forecast error, variable } Y \text {, time } t \text { (these } \\
& \text { are the errors discussed in Chapter 4) } \\
& E_{Y, x, t}=\text { incorrect exogenous information error } \\
& \text { component, variable } Y \text {, time } t \\
& E_{1, v, t}=\underset{t}{\text { data revisions component, variable } Y \text {, time }} \\
& E_{Y, r,}=\text { model specification and residual error }
\end{aligned}
$$

The actual calculation of the error components proceeds as follows:

$$
\begin{aligned}
& E_{Y, T, t}=Y_{1}(\text { act. })-Y_{1}(\text { fcst. }) \\
& E_{Y, x, t}=Y_{1}(r 0)-Y_{1}(\text { fcst. }) \\
& E_{Y, v, t}=Y_{1}(r 1)-Y_{t}(r 0) \\
& E_{Y, r, t}=E_{Y, T, t}-E_{Y, x, t}-E_{Y, v, t}
\end{aligned}
$$

where:

$$
\begin{aligned}
& Y_{1}(\text { act. })= \text { actual value of endogenous variable } Y \\
& Y_{1}(\text { fcst. })= \text { original forecast value for } Y \\
& Y_{1}(\mathrm{r} 0)= \begin{aligned}
\text { resimulation of } Y \text { with correct exogenous } \\
\text { inputs }
\end{aligned} \\
& Y_{1}(\mathrm{r} 1)=\begin{array}{l}
\text { resimulation of } Y \text { with correct exogenous } \\
\text { inputs and data revisions }
\end{array}
\end{aligned}
$$

Aside from demonstrating whether or not the $\mathrm{E}_{\mathrm{Y}, \mathrm{T}, 1}$ 's are small, it will be of interest to see if the $E_{Y, r, t}$ 's are small in co.nparison to $E_{Y, T,}$, since that will be indicative of the model providing good representations of the endogenous variables conditional upon having correct exogenous inputs. Although the $E_{Y, x, 1}$ 's could also be discussed separately, they will be ignored for the rest of this analysis. ${ }^{49}$ Given that $E_{Y, r, t}$ is generally expected

\footnotetext{
"As it turns out, the $E_{\gamma}, x, t$ 's were small for the calculations done in this report, as expected. They may be obtained from the authors upon request.
} 
to be less than $E_{Y, T, t}$ in absolute value, ${ }^{50}$ a conservative summary measure with which to compare total and residual errors is the mean absolute percent error (MAPE). The MAPE is defined as:

$$
\begin{aligned}
& \operatorname{MAPE}_{Y, T}=\left\{(1 / N) * \sum_{t=1}^{N}\left\{\left|E_{Y, T, t}\right| / Y t\right\}\right\} 100 \\
& \operatorname{MAPE}_{Y, x}=\left\{(1 / N) * \sum_{i=1}^{N}\left\{\left|E_{Y, x, t}\right| / Y t\right\} \mid 100\right. \\
& \operatorname{MAPE}_{Y, r}=\left\{(1 / N) * \sum_{i=1}^{N}\left\{\left|E_{Y, r, t}\right| / Y t\right\} \mid 100\right.
\end{aligned}
$$

where:

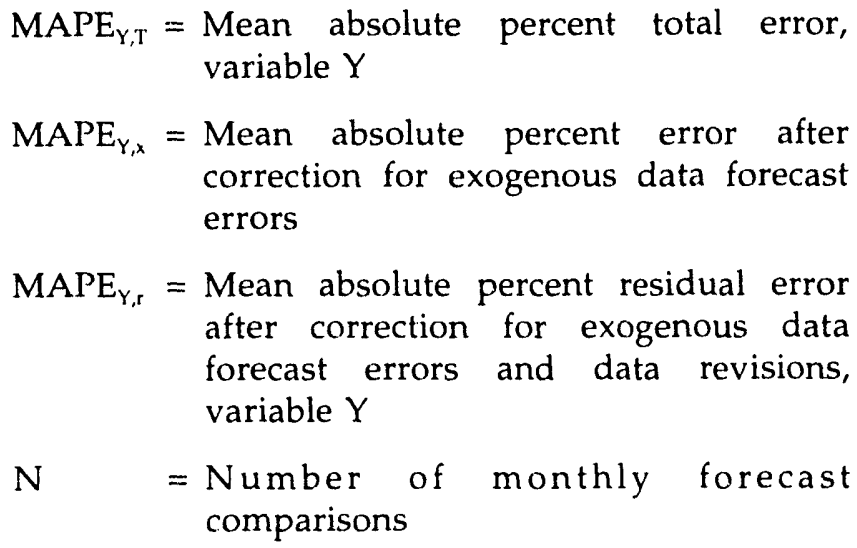

An indicator of the extent to which ex post corrections to exogenous inputs reduces out-of-sample forecast errors is the ratio of (8) to (6), which may be labeled the $\mathrm{r}-\mathrm{T}$ ratio. High $\mathrm{r}-\mathrm{T}$ ratios, particularly those that exceed 1.0 are indicative of potential specification problems affecting particular variables. These will be of particular concern where the MAPE $E_{\gamma, T}$ tends to be large or are associated with key variables used in sensitivity analysis or policy-related analysis.

For the STIFS model, which is generally used to provide energy forecast reports in which the data are aggregated to quarterly averages even though the underlying projections are monthly, it may be useful to examine a modified $\mathrm{r}-\mathrm{T}$ ratio based on moving threemonth averages for the forecast variables. It is possible that the model will capture quarterly movements in energy variables if not the precise timing of monthly variations. The modified $\mathrm{r}-\mathrm{T}$ ratio is based on the following definitions of MAPE's:

$$
\begin{aligned}
& \text { (9) } \operatorname{MAPE}_{Y, T} \cdot=\left\{(1 /(\mathrm{N}-2)) * \sum_{i-3}^{N 1} \mid \sum_{i-j, 2}^{j}\left\{\left|\mathrm{E}_{Y, 1, t}\right|\right\}\right. \\
& \sum_{1-i 2}^{i} Y_{H} \mid l * 100 \\
& \operatorname{MAPE}_{Y, x}=\left\{(1 /(\mathrm{N}-2)) * \sum_{j-3}^{N 1}\left|\sum_{1-j 2}^{j}\right|\left|E_{Y, \mathrm{~T}, \mathrm{t}}\right|\right\} \\
& \sum_{i-j 2}^{j} Y_{t} \| * 100
\end{aligned}
$$

$$
\begin{aligned}
\operatorname{MAPE}_{Y, r}=\left\{(1 /(\mathrm{N}-2)) * \sum_{i-3}^{N 1} \mid\right. & \sum_{\substack{i-j 2 \\
j}}^{j}\left\{\left|E_{Y, r, t}\right|\right\} \\
& \sum_{i=j 2}^{j} Y_{t} \| * 100
\end{aligned}
$$

While it is generally expected that the MAPE's will be smaller than the MAPE's, this is not guaranteed..$^{51}$ However, it is indicative of a biased forecast for MAPE' to exceed MAPE, since otherwise the moving average characteristics of MAPE' would tend to reduce average percentage errors.

\section{Results from the Fourth Quarter 1992 STEO}

Table 11 provides a summary of STIFS forecast errors for selected variables from the fourth quarter 1993 Short-Term Energy Outlook, indicating the MAPE's and the three-month MAPE's with corresponding r-T ratios. These statistics were based on only 7 months of data (September 1992 through March 1993), which was the extent of the actual data available for ex post resimulation..$^{52}$ The NA's indicate that a resimulation could not be done because the variable was provided exogenously to the STIFS system.

Of the 24 endogenous variables selected, 4 had $\mathrm{r}-\mathrm{T}$ ratios based on MAPE's that indicated as much as or more than a 50-percent reduction in total forecast error with ex post resimulation. These cases were for some of the larger forecast errors encountered, including the selected petroleum product prices, whose errors were

\footnotetext{
51It is possible for the reverse to be true (i.e. $\left|E_{Y, r, 1}\right|>\left|E_{Y, T, 1}\right|$ ), which would in iicate an instance in which model-related error exceeded observed total forecast error. This is a generalized statement of what one mighi call the "correct-for-the-wrong-reason phenomenon."

"A situation in which MAPE < MAPE* is easy to demonstrate from a numerical example, which is provided upon request.

${ }^{52}$ In future reports this particular resimulation will be revisited in order to provide more data points and to track progress in STIFS forecast performance by redoing the simulation with out-of-sample forecasts from future model versions.
} 
Table 11. Mean Absolute Percent Errors for Selected Variables

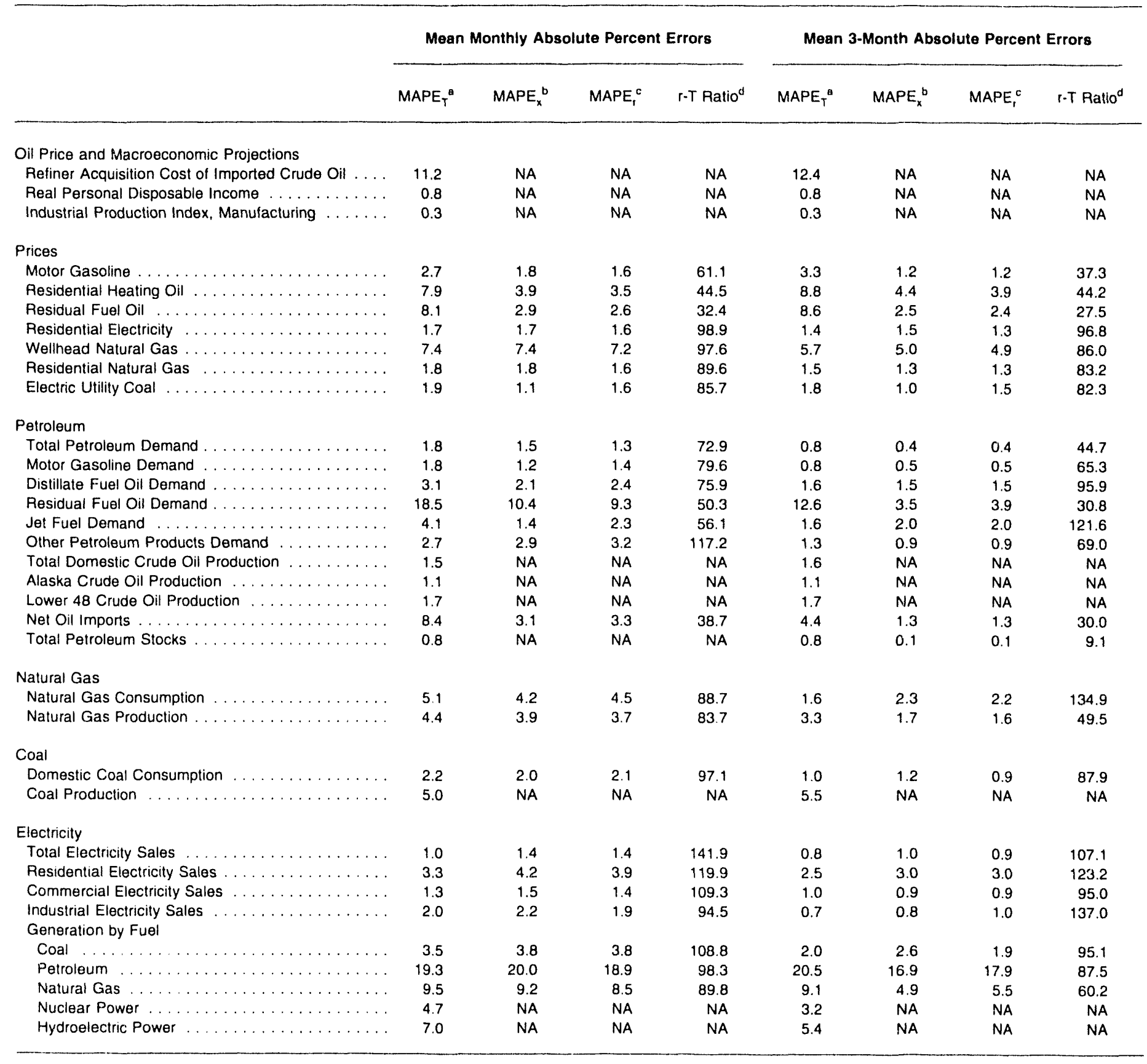

${ }^{a}$ Mean absolute percent error, for total fore, ast error.

${ }^{\mathrm{b}}$ Mean absolute percent error, for forecast $\theta$, ror remaining after correcting for exogenous inputs only (no data revisions or reestimation).

'Mean absolute percent error, for residual forecast error remaining after corrected exogenous inputs and data revisions included in expost reestimation and resimulation.

Defined as MAPE, / MAPET. 
largely conditioned by the 11-percent total error in the crude oil price. A much larger number of variables with 50-percent or greater error reduction on ex post resimulation appear based on MAPE*'s.

About one-fifth of the selected variables that could be resimulated had $r-T$ ratios based on MAPE's that exceeded 100 percent, indicating a resilience of forecast errors for these variables to exogenous input corrections. A similar fraction of the selected resimulated variables exhibited $r-T$ ratios over 10$)$ percent based on the MAPE*'s.

As expected, the MAPE*'s were lower than the MAPE's in the majority of the cases, the main exceptions coming from the petroleum price variables. Here, a run of errors of the same sign is of course suspected. Over the relatively short forecast period featured in Table 11 , crude oil prices were consistently overpredicted in the base case, leading to similarly biased forecasts for petroleum product prices (Figure 3).

It is apparent that the residual errors were significant and even dominant components of the overall forecast errors generated by the base case STIFS run for the fourth quarter 1992 Outlook. On the other hand, for the limited sample of points summarized in Table 11, the errors do not appear to be exceedingly large, falling within the 1 to 3 percent range for most of the key endogenous variables based on MAPE's (and within the 1 to 2 percent range based on MAPE*'s). The results from Table 11 will be updated as more data become available, and will serve as a benchmark forecast error summary for future comparison.

\section{STIFS Forecast Standard Errors}

A more complete view of the kinds of uncertainty inherent in STIFS forecasts is obtained by generating
Figure 3. Forecast Errors for the Price of Imported Crude Oil

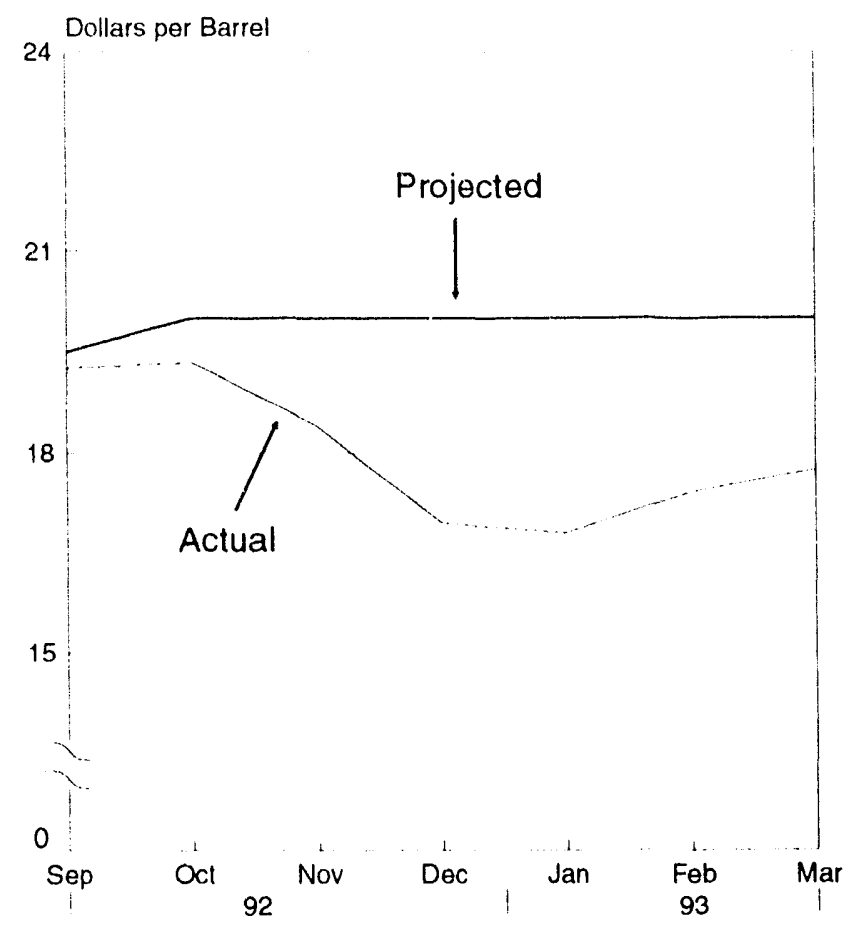

forecast standard errors based on the stochastic nature of the STIFS model equations and estimated parameters. The technique used to generate forecast standard errors is the repeated simulation of the entire STIFS model (over a specified time horizon) with simultaneous random perturbations of the model parameters and equation errors. ${ }^{53}$

\footnotetext{
${ }^{53}$ The random perturbations are affected by utilizing the parameter and equation error covariance matrices captured from the STIFS estimation routine. All parameters and error terms (excluding autoregressive components) are assumed to be normally distributed. A random draw for each observation (a vector of shocks) is made from the multivariate normal distribution defined for the equation errors based on the covariance matrix of error terms saved during model estimation. The vector of shocks to the error terms is held constant through all iterations of the model solution process for a given observation for a particular repetition. A random draw for each repetition (a vector of shocks) is made from the multivariate normal distribution defined for the model parameters based on the parameter covariance matrix saved during model estimation. Thus, the perturbed model parameter values remain constant for all iterations required for all observations in a repetition. A repetition is defined as a complete model solution through the specified time horizon. For the analysis done here, 461 repetitions were done for 24 time periods (months), which translates into a total 11,064 draws on the error distribution and 461 draws on the parameter distribution. From an initial attempt to generate 500 random repetitions, 462 were completed with minimal model execution errors (extreme value problems, illegal arguments in log functions, etc.). One repetition from the 462 successful ones was thrown out because it generated non-fatal illegal conditions, including several negative prices. All other repetitions appeared to generate plausible (if sometimes extreme) model results. A more complete docu'nentation of the procedure as applied to the STIFS model is available from the SAS Institute Incorporated, SAS/LTS User's Guide, Version 6 (1988). The structure of the STiFS model itself is described in Energy Information Administration, Short-Term Integrated Forecasting System: 1993 Model Documentation Report, DOE/EIA-MO41(4.3).
} 
In order to make the estimated forecast standard errors as comprehensive and unconditional as possible, the STIFS model had to be extended to incorporate uncertainty in variables normally taken to be exogenous. ${ }^{5-4}$ The variables of greatest interest in this regard were key macroeconomic variables (output, employment, aggregate income, etc.), crude oil prices, and weather. Other key exogenous variables that were made stochastic for the Monte Carlo runs were hydroelectric and nuclear power generation, and domestic crude oil production. Documentation of the complete extension of STIFS used to derive the probability distributions for exogenous inputs is provided in Appendix B. The specifications used here are fairly simple but appear to result in quite reasonable forecasts in their own right. They are, however, only a convenient substitute for the actual process that generates the exogenous inputs to STIFS. Since relatively naive models for the exogenous input variables are used in this exercise, it is assumed that the uncertainty from these sources is overstated slightly.

\section{Formal Description}

The forecast standard errors calculated for this report are defined as follows:

$$
s_{i, 1}=\left\{(1 /(R-1)) \sum_{i-1}^{R}\left(\hat{Y}_{i, 1, t}^{\tau}-\bar{Y}_{i, 1}^{\tau}\right)^{2}\right\}^{1 / 2}
$$

where:

$$
\begin{aligned}
s_{i, t}= & \text { forecast standard error for endogenous } \\
& \text { variable } i, \text { time period } t \text {, given initial } \\
& \text { conditions } \tau
\end{aligned}
$$

$\hat{Y}_{i, j, t}^{\tau}=$ solution value for endogenous variable $i$, random simulation repetition $j$, time period $t$, given initial conditions $\tau$

$\bar{Y}_{1, t}^{\tau}=$ mean solution value for endogenous variable $i$, across all random simulation repetitions, time period $t$, given initial conditions $\tau$

$\mathrm{R}$ = number of repetitions
Furthermore (dropping the $\tau$ superscript for convenience):

$$
\hat{Y}_{i, j, t}=F\left(\tilde{Y}_{i, r}, \tilde{Z}_{1, l}, X_{t}, b_{i}, e_{i, j, t}\right)
$$

where:

$F\left({ }^{*}\right)=a$ (possibly nonlinear) function of included endogenous variables, exogenous variables, structural parameters and a disturbance term)

$\tilde{Y}_{\mathrm{j}, \mathrm{t}}=$ vector of solution values for included endogenous variables (i.e. excluding variable i), repetition $j$, time period $t$

$Z_{\mathrm{j}, \mathrm{t}}=$ random draw from the multivariate distribution of exogenous variables made stochastic for this experiment, repetition j, time period $t$

$$
X_{t}=\begin{aligned}
& \text { vector of remaining (non-stochastic) } \\
& \text { exogenous variables, time } t
\end{aligned}
$$

$b_{i}=$ random draw from the multivariate distribution of estimated model parameters, repetition $j$

$e_{i, t}=$ element $i$ from the random draw from the multivariate distribution of model equation errors, repetition $j$, time period $t$

The autonomous shock $e_{i, j, t}$ is zero for all $\tilde{Y}_{i, j, t}$ defined as identities in the STIFS model.

\section{Numerical Results}

Table 12 provides forecast standard error statistics for the same variables selected for discussion throughout this chapter. ${ }^{55}$ The standard errors are reported relative to the mean (i.e., the standard error divided by the mean value of the forecast for each time period in the experiment) and are averaged to quarterly values. The simulation period for each repetition in the Monte Carlo runs underlying Table 12 was January 1993 to December 1994. Therefore, the first quarter shown on the table is based on results for the first quarter of 1993

\footnotetext{
${ }^{54}$ Some key exogenous variables were not made stochastic for this analysis, including petroleum stocks, coal production, and natural gas productive capacity. Planned model changes and enhancements will make a more complete specification of model uncertainty possible in the future.

${ }^{55}$ Forecast standard errors for any other endogenous variable from STIFS is available upon request.
} 
and the eighth quarter shown is based on results for the fourth quarter of 1994 . Although the forecast standard errors were generated based on a particular set of projections from the second quarter 1993 Outlook, the general time profile of the standard errors underlying Table 12 is useful in assessing the uncertainty of other STIFS forecasts generated close to (within one year of) of 1993. However, seasonality in the underlying variables may cause relative standard errors to rise nonmonotonically over the forecast period. The zeros in the table reflect the continued exogeneity of certain variables.

As can be seen from Table 12, a significant amount of uncertainty should be attached to certain price and fuel oil demand projections from STIFS. For crude oil prices the implied approximate 95-percent confidence bands fan out to a total range of plus or minus $\$ 7.50$ per barrel ( 37.6 percent) after 8 quarters, assuming a steady baseline projection of $\$ 20$ per barrel. ${ }^{56}$ Very similar absolute ranges up or down in prices for petroleum products would be required to obtain 95percent confidence bands, although the percentages involved (14.8 percent for gasoline retail price, 19.4 percent for residential heating oil and 50 percent residual fuel oil) may vary significantly depending on whether the price contains transportation, marketing and other costs or taxes.

A few calculations make it clear that crude oil prices dominate the uncertainty for petroleum product price forecasts. With an eight-quarter average relative standard error of 16.9 percent for crude oil prices,
6.4 percent for retail gasoline, 8.8 percent for residential heating oil, and 22 percent for residual fuel oil, in dollars per barrel these standard errors translate roughly into $\$ 3.19$ per barrel for crude oil, $\$ 3.25$ for gasoline, $\$ 3.57$ for heating oil and $\$ 3.32$ for residual fuel oil (based on fourth quarter 1992 Outlook averages ${ }^{57}$ ), almost a one-to-one correspondence. A more accurate view of the incremental contribution to total forecast uncertainty from crude oil prices could be constructed by redoing the Monte Carlo runs with crude oil prices held fixed throughout, and comparing the results to the those reported in Table 12. Future reports may be used to examine the relative contributions of various model inputs to overall forecast uncertainty.

Of the major petroleum products, residual fuel oil appears to have the greatest relative forecast uncertainty, based on relative standard errors of up to 17 percent for eight quarter-ahead forecasts. Much of this uncertainty stems from the large relative standard errors obtained for petroleum-based electric power generation, which is mostly (about 95 percent) associated with heavy fuel oil use. This product exhibited significant residual error from the forecast resimulations discussed earlier in this section, and, along with "other petroleum products," contributed heavily to the overall petroleum demand errors summarized in Chapter 4.

Illustrations of the 95-percent confidence bands (averaged to quarterly values) are presented in Figure 4 for crude oil price, retail gasoline price, residual fuel oil price and residual fuel oil demand.

\footnotetext{
m It should be said that one could easily justify assigning a greater degree of uncertainty to crude oil prices than is done for this analysis, since the crude (ril price representation detailed in Appendix B is purposely estimated over a time period (mid-1986 to early 1993) which, except for the Gulf War-related spike in prices seen in the fall 1990, was a period of relatively steady prices. Even here, the effects of potential events such as the Culf War on oil price uncertainty have been minimized by the use of a dummy variable during the period of the price spike.

"See Energy Information Administration, Short-Term Energy Outlook, DOE/EIA-(202(9)3/2Q), Table 5. The average prices used in the calculations were arithmetic averages for 1993 and 1994.
} 
Table 12. Relative Forecast Standard Errors ${ }^{a}$ for Selected STIFS Variables

(Percent)

\begin{tabular}{|c|c|c|c|c|c|c|c|c|}
\hline & \multicolumn{8}{|c|}{ Quarters Ahoad" } \\
\hline & 1 & 2 & 3 & 4 & 5 & 6 & 7 & 8 \\
\hline \multicolumn{9}{|l|}{ Oil Price and Macroeconomic Projections } \\
\hline Refiner Acquisition Cost of Imported Crude Oil ..... & 11.3 & 15.8 & 16.8 & 18.1 & 18.3 & 18.2 & 18.3 & 18.8 \\
\hline Real Personal Disposable Income $\ldots \ldots \ldots \ldots$ & 0.4 & 1.0 & 1.4 & 1.8 & 2.1 & 2.4 & 2.7 & 3.0 \\
\hline Industrial Production Index, Manufacturing $\ldots \ldots \ldots$ & 0.8 & 1.2 & 1.5 & 1.8 & 2.2 & 2.5 & 2.8 & 3.1 \\
\hline \multicolumn{9}{|l|}{ Prices } \\
\hline$\ldots \ldots \ldots \ldots \ldots \ldots$ & 3.5 & 5.5 & 6.3 & 6.9 & 7.2 & 7.1 & 7.1 & 7.4 \\
\hline Residential Heating Oil $\ldots \ldots \ldots \ldots \ldots$ & 5.3 & 8.1 & 9.0 & 9.2 & 9.1 & 9.8 & 10.2 & 9.7 \\
\hline Residual Fuel Oil $\ldots \ldots \ldots \ldots \ldots \ldots$ & 13.3 & 20.1 & 22.1 & 22.8 & 22.8 & 24.5 & 25.1 & 24.4 \\
\hline Residential Electricity $\ldots \ldots \ldots \ldots \ldots \ldots \ldots$ & 1.0 & 1.2 & 1.3 & 1.4 & 1.5 & 1.6 & 1.8 & 2.1 \\
\hline$\ldots \ldots \ldots \ldots \ldots \ldots$ & 6.3 & 12.0 & 14.0 & 13.4 & 14.2 & 16.5 & 16.4 & 15.3 \\
\hline Residential Natural Gas $\ldots \ldots \ldots \ldots \ldots \ldots \ldots$ & 1.4 & 2.1 & 2.4 & 2.7 & 3.0 & 3.4 & 3.8 & 3.9 \\
\hline Electric Utility Coal $\ldots \ldots \ldots \ldots \ldots \ldots \ldots$ & 0.8 & 1.2 & 1.4 & 1.6 & 1.7 & $1 . \varepsilon$ & 1.9 & 2.0 \\
\hline \multicolumn{9}{|l|}{ Petroleum } \\
\hline Total Petroleum Demand. & 1.9 & 2.0 & 2.1 & 2.6 & 2.9 & 2.3 & 2.3 & 2.7 \\
\hline Motor Gasoline Demand . & 1.9 & 2.1 & 2.2 & 2.2 & 2.3 & 2.3 & 2.3 & 2.4 \\
\hline Distillate Fuel Oil Demand & 4.9 & 5.5 & 5.6 & 5.8 & 5.6 & 5.4 & 5.8 & 5.9 \\
\hline Residual Fuel Oil Demand $\ldots \ldots \ldots \ldots \ldots \ldots$ & 10.2 & 14.3 & 17.2 & 16.1 & 16.0 & 16.4 & 18.7 & 16.9 \\
\hline Jet Fuel Demand $\ldots \ldots \ldots \ldots \ldots \ldots \ldots \ldots \ldots$ & 3.3 & 4.3 & 5.2 & 6.1 & 6.7 & 7.1 & 7.5 & 8.1 \\
\hline Other Petroleum Products Demand $\ldots \ldots \ldots \ldots$ & 3.4 & 3.4 & 3.4 & 4.3 & 4.9 & 3.8 & 3.6 & 4.5 \\
\hline Total Domestic Crude Oil Production . . . . . . . . . . & 1.8 & 2.7 & 3.5 & 4.2 & 4.8 & 5.3 & 5.6 & 6.3 \\
\hline Alaska Crude Oil Production $\ldots \ldots \ldots \ldots \ldots$ & 4.5 & 7.2 & 9.4 & 11.2 & 13.0 & 14.7 & 16.3 & 18.0 \\
\hline Lower 48 Crude Oil Production $\ldots \ldots \ldots \ldots \ldots$ & 1.9 & 2.8 & 3.6 & 4.2 & 4.8 & 5.2 & 5.6 & 6.2 \\
\hline$\ldots \ldots \ldots \ldots \ldots$ & 7.2 & 7.7 & 8.0 & 9.7 & 11.4 & 9.3 & 8.9 & 10.4 \\
\hline Tolal Petroleum Stocks' & 0.0 & 0.1 & 0.1 & 0.1 & 0.1 & 0.0 & 0.0 & 0.0 \\
\hline \multicolumn{9}{|l|}{ Natural Gas } \\
\hline Natural Gas Consumption & 2.7 & 4.5 & 6.0 & 4.9 & 3.6 & 5.7 & 7.1 & 5.6 \\
\hline Naturai Gas Production $\ldots \ldots \ldots \ldots \ldots \ldots \ldots$ & 4.6 & 6.0 & 6.3 & 5.5 & 5.3 & 6.4 & 7.4 & 6.3 \\
\hline \multicolumn{9}{|l|}{ Coal } \\
\hline Domestic Coal Consumption $\ldots \ldots \ldots \ldots \ldots$ & 2.3 & 3.2 & 3.3 & 4.0 & 4.2 & 4.5 & 4.6 & 5.0 \\
\hline Coal Production ${ }^{c} \ldots \ldots \ldots \ldots \ldots \ldots \ldots$ & 0.0 & 0.0 & 0.0 & 0.0 & 0.0 & 0.0 & 0.0 & 0.0 \\
\hline \multicolumn{9}{|l|}{ Electricity } \\
\hline Tota! Electricity Sales & 1.2 & 1.6 & 1.5 & 1.8 & 1.8 & 1.8 & 1.9 & 2.1 \\
\hline Residential Electricity Sales $\ldots \ldots \ldots \ldots \ldots \ldots$ & 2.8 & 3.7 & 3.1 & 3.9 & 3.2 & 3.6 & 3.3 & 3.6 \\
\hline Commercial Electricity Sales $\ldots \ldots \ldots \ldots \ldots$ & 1.0 & 1.6 & 1.5 & 1.8 & 1.9 & 2.0 & 2.0 & 2.1 \\
\hline Industrial Electricity Sales $\ldots \ldots \ldots \ldots \ldots \ldots$ & 0.9 & 1.7 & 2.1 & 2.4 & 2.8 & 3.1 & 3.3 & 3.6 \\
\hline \multicolumn{9}{|l|}{ Generation by Fuel } \\
\hline Coal $\ldots \ldots \ldots$. & 2.8 & 4.0 & 4.1 & 5.0 & 5.2 & 5.6 & 5.6 & 6.4 \\
\hline Petroleum ... ... & 17.6 & 27.0 & 30.3 & 36.5 & 32.0 & 31.5 & 32.9 & 40.5 \\
\hline Natural Gas & 12.8 & 14.3 & 14.9 & 21.7 & 23.6 & 20.5 & 19.5 & 28.6 \\
\hline$\ldots \ldots \ldots \ldots \ldots$ & 5.4 & 9.1 & 10.7 & 13.6 & 14.3 & 16.8 & 16.5 & 18.9 \\
\hline Hydroelectric Power $\ldots \ldots \ldots \ldots \ldots \ldots \ldots$ & 10.2 & 12.2 & 18.0 & 19.3 & 19.7 & 20.6 & 28.2 & 29.2 \\
\hline
\end{tabular}

"Defined as forecast standard errors divided by the expected value of the forecast variable at any forecast period given a set of initial conditions

'The quarters correspond to the first quarter of 1993 through the fourth quarter of 1994, and are presented relative to the second quarter 1993 Short-Term Energy Outlook mid oil price projections. The relative (percent) standard errors may rise or decline seasonally because of seasonality in the level of the underlying variable.

'Zeros indicate varlables which remained strictly exogenous for the Monte Carlo runs used to generate forecast standard errors. 
Figure 4. Approximate 95-Percent Confidence Ranges for Selected Variables, 2Q/93 STEO

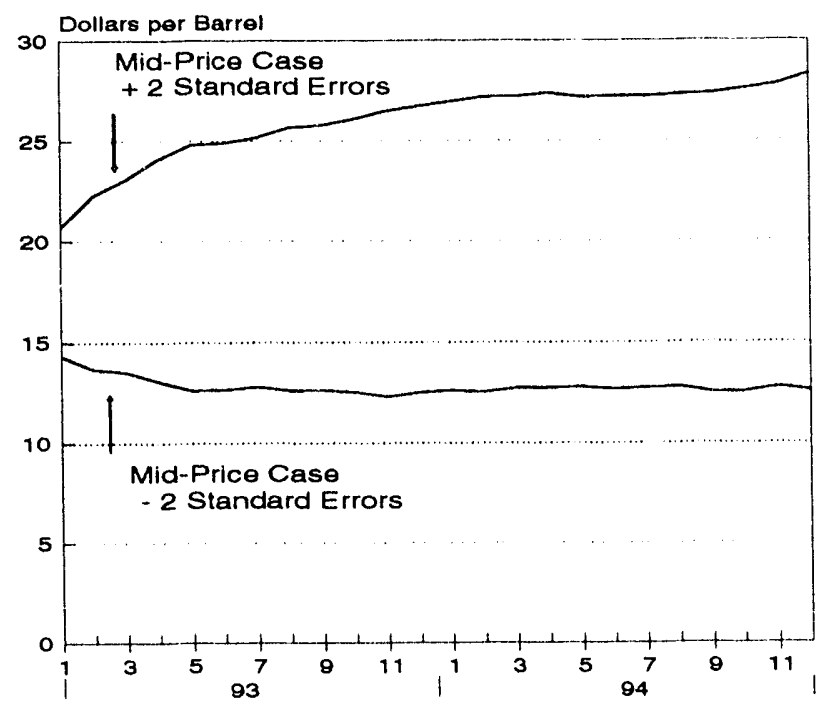

Imported Refiner Acquisition Cost of Crude Oil

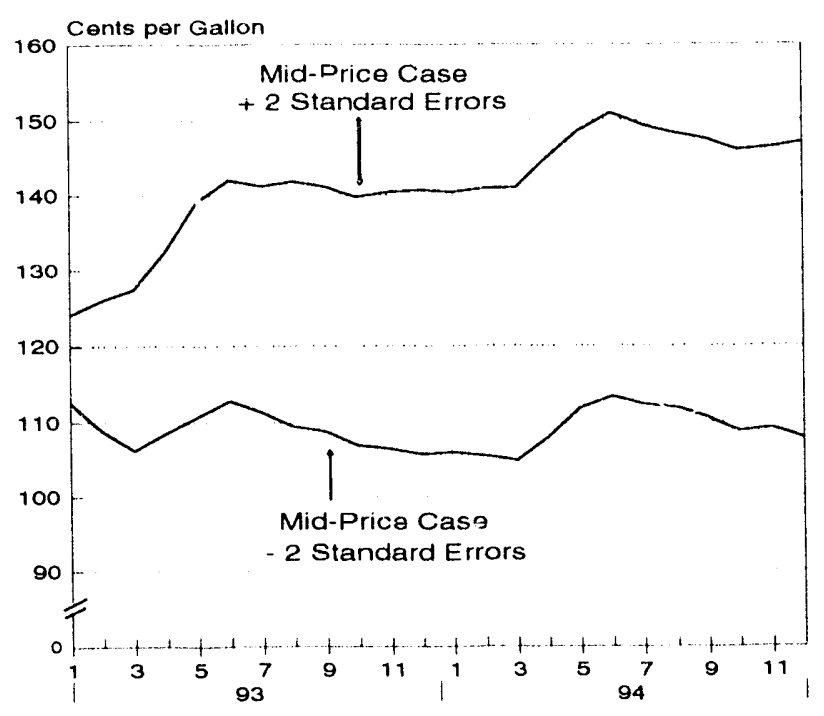

Retail Motor Gasoline Price

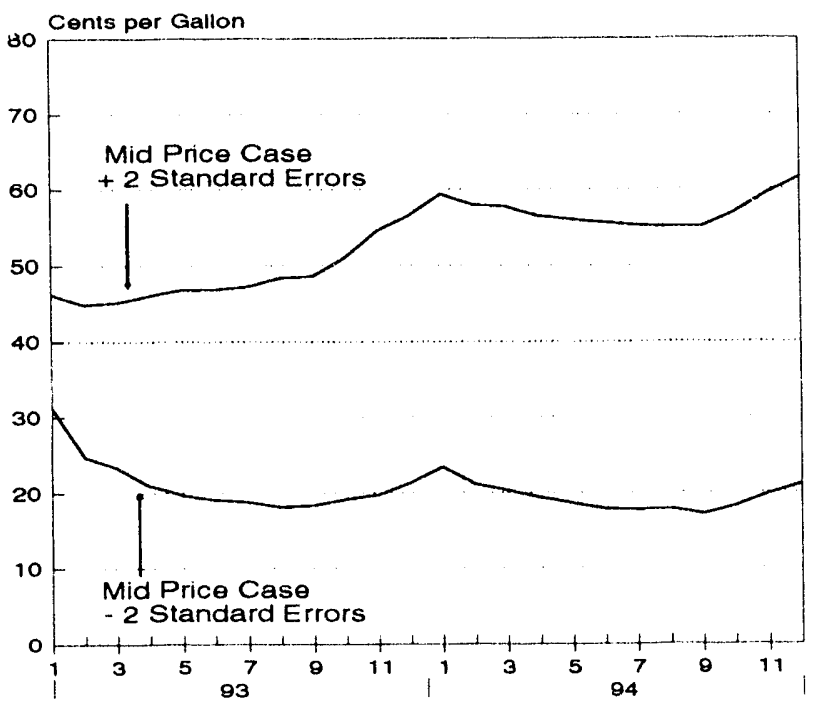

Residual Fuel Oil Price

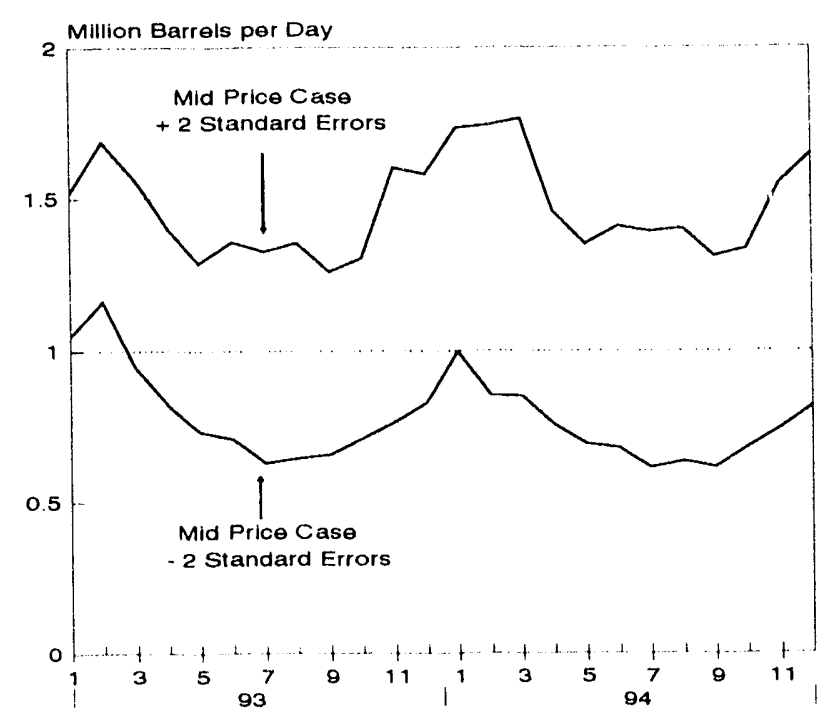

Residual Fuel Oil Demand 
Appendix A

\section{Detailed Forecast Error Tables}


Table A1. Refiner Acquisition Cost of Imported Crude Oil, Actual Versus Forecasts

\begin{tabular}{|c|c|c|c|c|c|c|c|}
\hline \multirow{3}{*}{ Forecast Report } & \multicolumn{6}{|c|}{ Forecasl Quarter } & \multirow{3}{*}{$\begin{array}{c}\text { Average } \\
\text { Absolute } \\
\text { Error }\end{array}$} \\
\hline & \multicolumn{2}{|c|}{1991} & \multicolumn{4}{|c|}{1992} & \\
\hline & $3 r d$ & 4 th & $1 \mathrm{st}$ & 2nd & $3 r d$ & 4 th & \\
\hline & \multicolumn{7}{|c|}{ (dollars per barrel) } \\
\hline $91 / 30$ & 19.00 & 20.00 & 20.00 & 2000 & 2000 & 21.00 & 1.63 \\
\hline $91 / 40$ &.$\cdot$ & 20.00 & 20.00 & 2000 & 20.00 & 20.00 & 1.68 \\
\hline $92 / 10$ & -. & .. & 18.00 & 18.00 & 19.00 & 20.00 & 1.19 \\
\hline $92 / 20$ & -. & .. & .. & 17.00 & 18.00 & 19.00 & 1.31 \\
\hline $92 / 30$ & -. & -. & -. & -. & 20.00 & 20.00 & 1.11 \\
\hline $92 / 40$ & $-\cdot$ & .. & .. & -. & .. & 20.00 & 1.64 \\
\hline Actual & 18.62 & 18.81 & 16.16 & 18.85 & 19.43 & 18.36 & \\
\hline \multirow[t]{2}{*}{ Average Absolute Error } & 0.38 & 1.19 & 3.17 & 125 & 0.71 & 1.64 & 1.46 \\
\hline & \multicolumn{7}{|c|}{ (percent erro, } \\
\hline $91 / 30$ & 2.0 & 6.3 & 23.8 & 6.1 & 2.9 & 14.4 & 8.9 \\
\hline $91 / 40$ & .. & 6.3 & 23.8 & 61 & 2.9 & 8.9 & 9.2 \\
\hline $92 / 10$ & .. & -. & 11.4 & -4.5 & -2.2 & 8.9 & 6.5 \\
\hline $92 / 20$ & -. &.$\cdot$ & $\cdot \cdot$ & -9.8 & -7.4 & 3.5 & 6.9 \\
\hline $92 / 30$ & .. & $\cdot \cdot$ & -. & -. & 2.3 & 8.9 & 5.8 \\
\hline $92 / 40$ & $\cdot \cdot$ & $\cdots$ & -. & -. & -. & 8.9 & 8.9 \\
\hline Average Absolute Percent Error & 2.0 & 63 & 19.6 & 6.6 & 37 & 8.9 & 8.2 \\
\hline
\end{tabular}

\section{- Not applicable}

Sources: Actual data are based on published numbers frorn the Energy Information Administration, Monthly Energy Review, DOE/EIA-0035(93/03); forecasts are taken from the base or mid-case scenarios of the Short-Term Energy Outlook.

\section{Table A2. Retail Motor Gasoline Prices, Actual Versus Forecasts}

\begin{tabular}{|c|c|c|c|c|c|c|c|}
\hline \multirow{3}{*}{ Forecas: Report } & \multicolumn{6}{|c|}{ Forecast Quanter } & \multirow{3}{*}{$\begin{array}{c}\text { Average } \\
\text { Absolute } \\
\text { Error }\end{array}$} \\
\hline & \multicolumn{2}{|c|}{1991} & \multicolumn{4}{|c|}{1992} & \\
\hline & 3rd & $4 \ln$ & $1 s t$ & 2nd & $3 r d$ & 4 th & \\
\hline
\end{tabular}

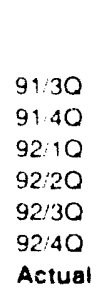

Average Absolute Error

91.40

$92: 10$

$92: 20$

$92 / 30$

Actual

$\begin{array}{rrr}1.22 & 1.21 & 1 \\ \cdots & 1.21 & 1 \\ -. & . & 1 \\ . . & \cdots & \\ . . & . . & \\ . . & 1.19 & 1 \\ 1.19 & & \\ & & \end{array}$

(doliars per gallon)

$94 / 30$

$9 ! / 40$

$92: 0$

9220

$92 / 30$

92.40

\begin{tabular}{cccc}
0.03 & 002 & 0.04 & 004 \\
\hline (percent error)
\end{tabular}

Average Absolute Percent Error

$\begin{array}{rr}23 & 2.1 \\ . . & 21 \\ . . & . \cdot \\ . . & \cdots \\ . . & \cdots \\ . . & \cdots\end{array}$

$117 \quad 1.25$

$1.17 \quad 1.25$

1.18

..

$+\cdot$

1.13

1.22
.-

12.7

1.23

$\begin{array}{rrr}1.28 & 1.27 & 0.04 \\ 1.28 & 1.27 & 0.05 \\ 1.25 & 1.25 & 0.02 \\ 1.22 & 1.24 & 0.02 \\ 12.7 & 1.28 & 0.05 \\ . . & 1.26 & 0.05 \\ 1.23 & 1.21 & \end{array}$

23

21

$\begin{array}{rr}4.0 & 4.8 \\ 40 & 48 \\ -2.2 & 41 \\ . . & .11 \\ . . & . . \\ . . & . . \\ & \\ 34 & 29\end{array}$

0.04

0.05

0.04

.. = Not applicable

Note Gasoline Prices are an average of all grades and services. including taxes

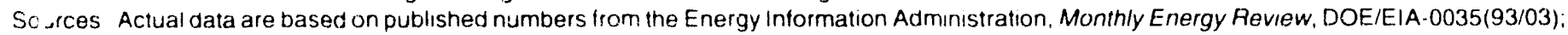
torecasts are laken from the base or mid-case scenarios of the Short-Term Energy Outlook. 
Table A3. Residential Heating Oil Prices, Actual Versus Forecasts

\begin{tabular}{|c|c|c|c|c|c|c|c|}
\hline \multirow{3}{*}{ Forecast Report } & \multicolumn{6}{|c|}{ Forecast Quarter } & \multirow{3}{*}{$\begin{array}{c}\text { Average } \\
\text { Absolute } \\
\text { Error }\end{array}$} \\
\hline & \multicolumn{2}{|c|}{1991} & \multicolumn{4}{|c|}{1992} & \\
\hline & $3 r d$ & 4th & $1 \mathrm{st}$ & 2nd & $3 r d$ & 4 th & \\
\hline & \multicolumn{7}{|c|}{ (dollars per gallon) } \\
\hline $91 / 30$ & 0.93 & 1.02 & 1.06 & 1.02 & 0.98 & 1.07 & 0.09 \\
\hline $91 / 4 \mathrm{Q}$ & -. & 1.02 & 1.06 & 1.00 & 0.97 & 1.05 & 0.09 \\
\hline $92 / 10$ & .. & .. & 0.97 & 0.92 & 0.90 & 1.00 & 0.02 \\
\hline $92 / 20$ & .. & .. & -. & 0.88 & 0.88 & 0.98 & 0.03 \\
\hline $92 / 30$ & -. &.. & .. & .. & 0.96 & 1.03 & 0.07 \\
\hline $92 / 4 \mathrm{O}$ &.. & -. & $\cdot \cdot$ & .. & -. & 1.02 & 0.08 \\
\hline Actual & 0.88 & 0.96 & 0.94 & 0.92 & 0.90 & 0.95 & \\
\hline \multirow[t]{2}{*}{ Average Absolute Error } & 0.05 & 0.06 & 0.09 & 0.06 & 0.05 & 0.08 & 0.07 \\
\hline & \multicolumn{7}{|c|}{ (percent error) } \\
\hline $91 / 30$ & 5.7 & 6.1 & 13.0 & 10.4 & 9.1 & 13.2 & 9.6 \\
\hline $91 / 40$ & $\cdot \cdot$ & 6.1 & 13.0 & 8.2 & 8.0 & 11.1 & 9.3 \\
\hline $92 / 10$ & $\cdot \cdot$ & .. & 3.4 & -0.4 & 0.2 & 5.8 & 2.5 \\
\hline $92 / 20$ & -. & .. & .. & .4 .8 & -2.0 & 3.7 & 3.5 \\
\hline $92 / 30$ & .. & .. & -. & -. & 6.9 & 9.0 & 8.0 \\
\hline $92 / 40$ & $-\cdot$ & -. & -. & $\cdot \cdot$ & $-\cdot$ & 7.9 & 7.9 \\
\hline Average Absolute Percent Error & 5.7 & 6.1 & 9.8 & 6.0 & 5.3 & 8.5 & 7.1 \\
\hline
\end{tabular}

* = Not applicable.

Sources: Actual data are based on published numbers from the Energy Information Administration, Monthly Energy Review, DOE/ElA. 0035(93/03); forecasts are taken from the base or mid-case scenarios of the Short-Term Energy Outlook.

Table A4. Residual Fuel Oil Prices, Actual Versus Forecasts

\begin{tabular}{|c|c|c|c|c|c|c|c|}
\hline \multirow{3}{*}{ Forecast Report } & \multicolumn{6}{|c|}{ Forecast Quarter } & \multirow{3}{*}{$\begin{array}{c}\text { Average } \\
\text { Absolute } \\
\text { Error }\end{array}$} \\
\hline & \multicolumn{2}{|c|}{1991} & \multicolumn{4}{|c|}{1992} & \\
\hline & 3rd & 4 th & $1 \mathrm{st}$ & 2nd & 3. & 4th & \\
\hline & \multicolumn{7}{|c|}{ (dollars per barrel) } \\
\hline $91 / 30$ & 14.53 & 17.17 & 18.00 & 16.96 & 17.03 & 19.02 & 3.05 \\
\hline $91 / 40$ & .. & 16.98 & 17.95 & 16.60 & 16.82 & 18.26 & 3.04 \\
\hline $92 / 10$ & .. & .. & 14.78 & 13.67 & 14.92 & 17.42 & 1.31 \\
\hline $92 / 20$ & .. & -. & .. & 11.73 & 13.20 & 15.68 & 1.61 \\
\hline $92 / 30$ & .. & .. & .. & .. & 14.68 & 16.95 & 1.05 \\
\hline $92 / 40$ & -- & $\ddot{*}$ & 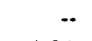 & $\cdot-$ & $\cdot \cdot$ & 16.85 & 0.86 \\
\hline Actual & 13.01 & 14.08 & 11.80 & 13.63 & 15.82 & 15.99 & \\
\hline \multirow[t]{2}{*}{ Average Absolute Error } & 1.52 & 3.00 & 5.01 & 2.06 & 1.37 & 1.48 & 2.21 \\
\hline & \multicolumn{7}{|c|}{ (percent error) } \\
\hline $91 / 30$ & 11.7 & 21.9 & 51.3 & 24.4 & 7.6 & 18.9 & 21.7 \\
\hline $91 / 40$ & .. & 20.6 & 50.8 & 21.8 & 6.3 & 14.2 & 21.3 \\
\hline $92 / 10$ & .. & .. & 24.2 & 0.3 & -5.7 & 8.9 & 9.2 \\
\hline $92 / 20$ & .. & -. & .. & -13.9 & -16.6 & $\cdot 1.9$ & 10.6 \\
\hline $92 / 30$ & .. & .. & .. & .. & -7.2 & 6.0 & 6.6 \\
\hline $92 / 40$ & .. & -. & -. & .. & .. & 5.4 & 5.4 \\
\hline Average Absolute Percent Error & 11.7 & 21.3 & 42.1 & 15.1 & 8.7 & 9.2 & 16.2 \\
\hline
\end{tabular}

.. = Not applicable.

Note: Prices are refiner retail sales, average of all sulfur contents.

Sources: Actual data are based on published numbers from the Energy Information Administration, Monthly Energy Review, DOE/EIA-0035(93/03); forecasts are taken from the base or mid-case scenarios of the Short-Term Energy Outlook. 
Table A5. Natural Gas Welihead Prices, Actual Versus Forecasts

\begin{tabular}{|c|c|c|c|c|c|c|c|}
\hline \multirow{3}{*}{ Forecast Roport } & \multicolumn{6}{|c|}{ Forecast Quarter } & \multirow{3}{*}{$\begin{array}{c}\text { Average } \\
\text { Absolute } \\
\text { Error }\end{array}$} \\
\hline & \multicolumn{2}{|c|}{1991} & \multicolumn{4}{|c|}{1992} & \\
\hline & 3 rd & 4th & $1 \mathrm{st}$ & 2nd & 3rd & 4th & \\
\hline & \multicolumn{7}{|c|}{ (dollars per thousand cubic feet) } \\
\hline $91 / 30$ & 1.65 & 1.99 & 1.89 & 1.58 & 1.76 & 2.15 & 0.17 \\
\hline $91 / 4 \mathrm{Q}$ & .. & 1.88 & 1.78 & 1.48 & 1.56 & 1.95 & 0.23 \\
\hline $92 / 10$ & $-\cdot$ & .. & 1.65 & 1.48 & 1.45 & 1.84 & 0.30 \\
\hline $92 / 20$ &.. & -. & $-\cdot$ & 1.35 & 1.49 & 1.69 & 0.45 \\
\hline $92 / 30$ & -. &.. & .. & - & 1.54 & 1.79 & 0.46 \\
\hline $92 / 40$ & .. &.. & -. & -. & -. & 2.20 & 0.14 \\
\hline Actual & 1.46 & 1.91 & 1.54 & 1.63 & 1.91 & 2.34 & \\
\hline \multirow[t]{2}{*}{ Average Absolute Error } & 0.19 & 0.06 & 0.24 & 0.16 & 0.35 & 0.40 & $0.8:$ \\
\hline & \multicolumn{7}{|c|}{ (percent error) } \\
\hline $91 / 3 Q$ & 13.4 & 4.5 & 22.9 & -3.1 & $\cdot 7.6$ & -8.2 & 9.4 \\
\hline $91 / 40$ & -. & -1.3 & 15.7 & -9.2 & -18.1 & -16.7 & 12.4 \\
\hline $92 / 10$ & -. & .. & 7.3 & -9.2 & -23.9 & -21.4 & 16.4 \\
\hline $92 / 20$ & $-\cdot$ & -. & -. & -17.2 & -21.8 & -27.8 & 22.9 \\
\hline $92 / 30$ & $\cdot \cdot$ & $-\cdot$ & .. & -. & -19.2 & -23.5 & 21.6 \\
\hline $92 / 40$ & $\cdots$ & -. &.$\cdot$ & -- & $\cdots$ & -6.0 & 6.0 \\
\hline Average Absolute Percent Error & 13.4 & 2.9 & 15.3 & 9.7 & 18.1 & 17.3 & 14.2 \\
\hline
\end{tabular}

-- Not applicable.

$F=$ Estimated.

Sources: Actual data are based on published numbers from the Energy Information Administration, Monthly Energy Review, DOE./EIA-0035(92/03); forecasts are taken from the base or mid-case scenarios of the Short-Term Energy Outlook.

Table A6. Residential Natural Gas Prices, Actual Versus Forecasts

\begin{tabular}{|c|c|c|c|c|c|c|c|}
\hline \multirow{3}{*}{ Forecast Report } & \multicolumn{6}{|c|}{ Forecast Quarter } & \multirow{3}{*}{$\begin{array}{c}\text { Average } \\
\text { Absolute } \\
\text { Error }\end{array}$} \\
\hline & \multicolumn{2}{|c|}{1991} & \multicolumn{4}{|c|}{1992} & \\
\hline & 3rd & 4in & $1 \mathrm{st}$ & 2nd & 3rd & 4 th & \\
\hline & & & & ousan & & & \\
\hline $91 / 30$ & 7.10 & 5.95 & 5.84 & 6.30 & 7.52 & 6.29 & 0.27 \\
\hline $91 / 40$ & -. & 5.87 & 5.68 & 6.14 & 7.25 & 6.03 & 0.13 \\
\hline $92 / 10$ & $-\cdot$ & $\cdot \cdot$ & 5.68 & 6.21 & 7.29 & 5.96 & 0.11 \\
\hline $92 / 20$ & $\cdot \cdot$ & *. & $\cdots$ & 615 & 7.23 & 5.88 & 0.07 \\
\hline $92 / 30$ & $\cdots$ & -. & $-\cdot$ & -- & 7.25 & 5.90 & 0.02 \\
\hline $92 / 40$ & .. &.- & $\cdot$. & $\cdot-$ & $\cdot \cdot$ & 5.98 & 0.05 \\
\hline Aciual & 7.16 & 5.62 & 5.52 & 6.00 & 7.24 & 5.93 & \\
\hline \multirow[t]{2}{*}{ Average Absolute Error } & 0.06 & 0.29 & 0.21 & 0.20 & 0.07 & 0.10 & 0.15 \\
\hline & \multicolumn{7}{|c|}{ (percent error) } \\
\hline $91 / 30$ & .0 .8 & 5.9 & 5.8 & 5.0 & 3.9 & 6.1 & 4.4 \\
\hline $91 / 40$ & $-\cdot$ & 4.4 & 2.9 & 2.3 & 0.1 & 1.7 & 2.2 \\
\hline $92 / 10$ & -. & $-\cdot$ & 2.9 & 3.5 & 0.7 & 0.5 & 1.8 \\
\hline $92 / 20$ & -- & -. & - & 2.5 & -0.1 & -0.8 & 1.1 \\
\hline $92 / 30$ & -. & -. & .. & -. & 0.1 & -0.5 & 0.3 \\
\hline $92 / 40$ & $-\cdot$ & $-\cdot$ & -. & $\cdots$ & $\cdots$ & 0.8 & 0.8 \\
\hline Average Absolute Percent Error & 0.8 & 5.2 & 3.9 & 3.3 & 1.0 & 1.7 & 2.4 \\
\hline
\end{tabular}

Average Absolute Percent Error 3.9

-. = Not applicable.

Scurces: Actual data are based on published numbers from the Energy Information Administration, Monthly Energy Review, DOE/EIA0035(93/03); torecasts are taken from the base or mid-case scenarios of the Short-Term Energy Outlook. 
Table A7. Residential Electricity Prices, Actual Versus Forecasts

\begin{tabular}{|c|c|c|c|c|c|c|c|}
\hline \multirow{3}{*}{ Forecast Report } & \multicolumn{6}{|c|}{ Forecast Quarter } & \multirow{3}{*}{$\begin{array}{c}\text { Average } \\
\text { Absolute } \\
\text { Error }\end{array}$} \\
\hline & \multicolumn{2}{|c|}{1991} & \multicolumn{4}{|c|}{1992} & \\
\hline & $3 r d$ & 4th & $1 \mathrm{st}$ & $2 n d$ & 3rd & 4 th & \\
\hline & \multicolumn{7}{|c|}{ (cents per kilowatthour) } \\
\hline $91 / 30$ & 8.40 & 8.00 & 7.70 & 8.30 & 8.60 & 8.10 & 0.03 \\
\hline $91 / 40$ & $\cdots$ & 7.90 & 7.80 & 8.40 & 8.60 & 8.20 & 0.04 \\
\hline $92 / 10$ & -. & .. & 7.70 & 840 & 8.60 & 8.20 & 0.05 \\
\hline $92 / 20$ & .. & $\cdots$ & -. & 8.30 & 8.50 & 8.10 & 0.07 \\
\hline $92 / 30$ & .. & $-\cdot$ & -. & -- & 8.50 & 8.00 & 0.15 \\
\hline $92 / 4 Q$ &.. & .. & -. & .. & .. & 8.00 & 0.20 \\
\hline Actual & 8.40 & 8.00 & 7.80 & 8.30 & 8.60 & 8.20 & \\
\hline \multirow[t]{2}{*}{ Average Absolute Error } & 0.00 & 0.05 & 0.07 & 0.05 & 0.04 & 0.10 & 0.06 \\
\hline & \multicolumn{7}{|c|}{ (percent error) } \\
\hline $91 / 30$ & 0.0 & 0.0 & -1.3 & 0.0 & 0.0 & -1.2 & 0.4 \\
\hline $91 / 4 Q$ & .- & -1.2 & 0.0 & 1.2 & 0.0 & 0.0 & 0.5 \\
\hline $92 / 10$ & .. & $\cdot \cdot$ & -1.3 & 1.2 & 0.0 & 0.0 & 0.6 \\
\hline $92 / 20$ & .. & -. & $-\cdot$ & 0.0 & -1.2 & -1.2 & 0.8 \\
\hline $92 / 30$ & $-\cdot$ & -. & $\cdots$ & -. & -1.2 & -2.4 & 1.8 \\
\hline $92 / 40$ & -. & -. & -. & -. & $\cdot$. & -2.4 & 2.4 \\
\hline Average Absolute Percent Error & 0.0 & 0.6 & 0.9 & 0.6 & 0.5 & 1.2 & 0.8 \\
\hline
\end{tabular}

-. = Not applicable.

Sources: Actual data are based on published numbers from the Energy Information Administration, Monthly Energy Review, DOE/EIA-D035(93/03); forecasts are taken from the base or mid-case scenarios of the Short-Term Energy Outlook.

Table A8. Electric Utility Coal Prices, Actual Versus Forecasts

\begin{tabular}{|c|c|c|c|c|c|c|c|}
\hline \multirow{3}{*}{ Forecast Report } & \multicolumn{6}{|c|}{ Forecast Quanter } & \multirow{3}{*}{$\begin{array}{c}\text { Average } \\
\text { Absolute } \\
\text { Error }\end{array}$} \\
\hline & \multicolumn{2}{|c|}{1991} & \multicolumn{4}{|c|}{1992} & \\
\hline & $3 r d$ & 4 th & $1 \mathrm{st}$ & 2nd & 3rd & 4 th & \\
\hline & \multicolumn{7}{|c|}{ (dollars per million Btu) } \\
\hline $91 / 30$ & 1.45 & 1.45 & 1.47 & 1.49 & 1.47 & 1.48 & 0.05 \\
\hline $91 / 40$ & .. & 1.46 & 1.47 & 1.48 & 1.46 & 1.47 & 0.05 \\
\hline $92 / 10$ & .. & .. & 1.45 & 1.46 & 1.45 & 1.45 & 0.04 \\
\hline $92 / 20$ & -. & -. & -. & 1.45 & 1.46 & 1.47 & 0.05 \\
\hline $92 / 30$ & .. & .. & .. & .. & 1.45 & 1.47 & 0.06 \\
\hline $92 / 4 Q$ & -. & -. & .. & .. &.. & 1.43 & 0.02 \\
\hline Actual & 1.43 & 1.42 & 1.42 & 1.43 & 1.40 & 1.41 & \\
\hline \multirow[t]{2}{*}{ Average Absolute Error } & 0.02 & 0.04 & 0.04 & 0.04 & 0.06 & 0.05 & 0.05 \\
\hline & \multicolumn{7}{|c|}{ (percent error) } \\
\hline $91 / 30$ & 1.4 & 2.1 & 3.5 & 4.2 & 5.0 & 5.0 & 3.5 \\
\hline $91 / 40$ & .. & 2.8 & 3.5 & 3.5 & 4.3 & 4.3 & 3.7 \\
\hline $92 / 10$ & .. & .. & 2.1 & 2.1 & 2.8 & 2.8 & 2.7 \\
\hline $92 / 20$ & .. & .. & .. & 1.4 & 4.3 & 4.3 & 3.3 \\
\hline $92 / 30$ & .. & .. & .. & .. & 3.6 & 4.3 & 3.9 \\
\hline $92 / 40$ & .. & .. & .. & .. & .. & 1.4 & 1.4 \\
\hline Average Absolute Percent Error & 1.4 & 2.5 & 3.1 & 2.8 & 4.1 & 3.7 & 3.3 \\
\hline
\end{tabular}

.. = Not applicable.

Sources: Actual data are based on published numbers from the Energy Information Administration, Monthly Energy Review, DOE/EIA. 0035(93/03); forecasts are taken from the base or mid-case scenarios of the Short-Term Energy Outlook. 
Table A9. Real Disposable Personal Income, Actual Versus Forecasts

\begin{tabular}{|c|c|c|c|c|c|c|c|}
\hline \multirow{3}{*}{ Forecast Report } & \multicolumn{6}{|c|}{ Forecast Quarter } & \multirow{3}{*}{$\begin{array}{c}\text { Average } \\
\text { Absolute } \\
\text { Error }\end{array}$} \\
\hline & \multicolumn{2}{|c|}{1991} & \multicolumn{4}{|c|}{1992} & \\
\hline & 3rd & 4 th & $1 \mathrm{st}$ & 2nd & 3rd & 4th & \\
\hline & \multicolumn{7}{|c|}{ (billion 1982 dollars) } \\
\hline $91 / 3 \mathrm{Q}$ & 3466 & 3478 & 3505 & 3522 & 3534 & 3548 & 55 \\
\hline $91 / 4 \mathrm{Q}$ & -- & 3495 & 3523 & 3542 & 3555 & 3571 & 36 \\
\hline $92 / 1 Q$ & - & $-\cdot$ & 3522 & 3551 & 3559 & 3578 & 32 \\
\hline $92 / 20$ & -. & -. & .. & 3597 & 3607 & 3626 & 20 \\
\hline $92 / 30$ & -. & - &.. & -. & 3609 & 3630 & 22 \\
\hline $92 / 40$ & -. & -. & -. & $\cdots$ & -. & 3588 & 26 \\
\hline Actual & 3512 & 3531 & 3566 & 3576 & 3581 & 3614 & \\
\hline \multirow[t]{2}{*}{ Average Absolute Error } & 46 & 45 & 49 & 34 & 30 & 33 & 36 \\
\hline & \multicolumn{7}{|c|}{ (percent error) } \\
\hline $91 / 30$ & -1.3 & -1.5 & -1.7 & -1.5 & -1.3 & -1.8 & 1.5 \\
\hline $91 / 4 Q$ & -- & -1.0 & -1.2 & -1.0 & -0.7 & -1.2 & 1.0 \\
\hline $92 / 10$ & -- & -. & -1.2 & -0.7 & -0.6 & -1.0 & 0.9 \\
\hline $92 / 2 Q$ & .. & -. & .- & 0.6 & 0.7 & 0.3 & 0.5 \\
\hline $92 / 30$ & -. & $-\cdot$ & -- & -. & 0.8 & 0.4 & 0.6 \\
\hline $92 / 40$ & -. & -. & $\cdot \cdot$ & .. & $\cdots$ & -0.7 & 0.7 \\
\hline Average Absolute Percent Error & 1.3 & 1.3 & 1.4 & 0.9 & 0.8 & 0.9 & 1.0 \\
\hline
\end{tabular}

-- = Not applicable.

Sources: History trom U.S. Department of Commerce, Bureau of Economic Analysis, Survey of Current Business, various issues. Forecasts, from: DRI/McGraw-Hill, Quarterly Model of U.S. Economy, CONTROL forecasts, adjusted for ElA oil price forecasts for: June 1991, September 1991, January 1992, March 1992, July 1992, and September 1992.

Table A10. Industrial Production Index for Manufacturing, Actual Versus Forecasts

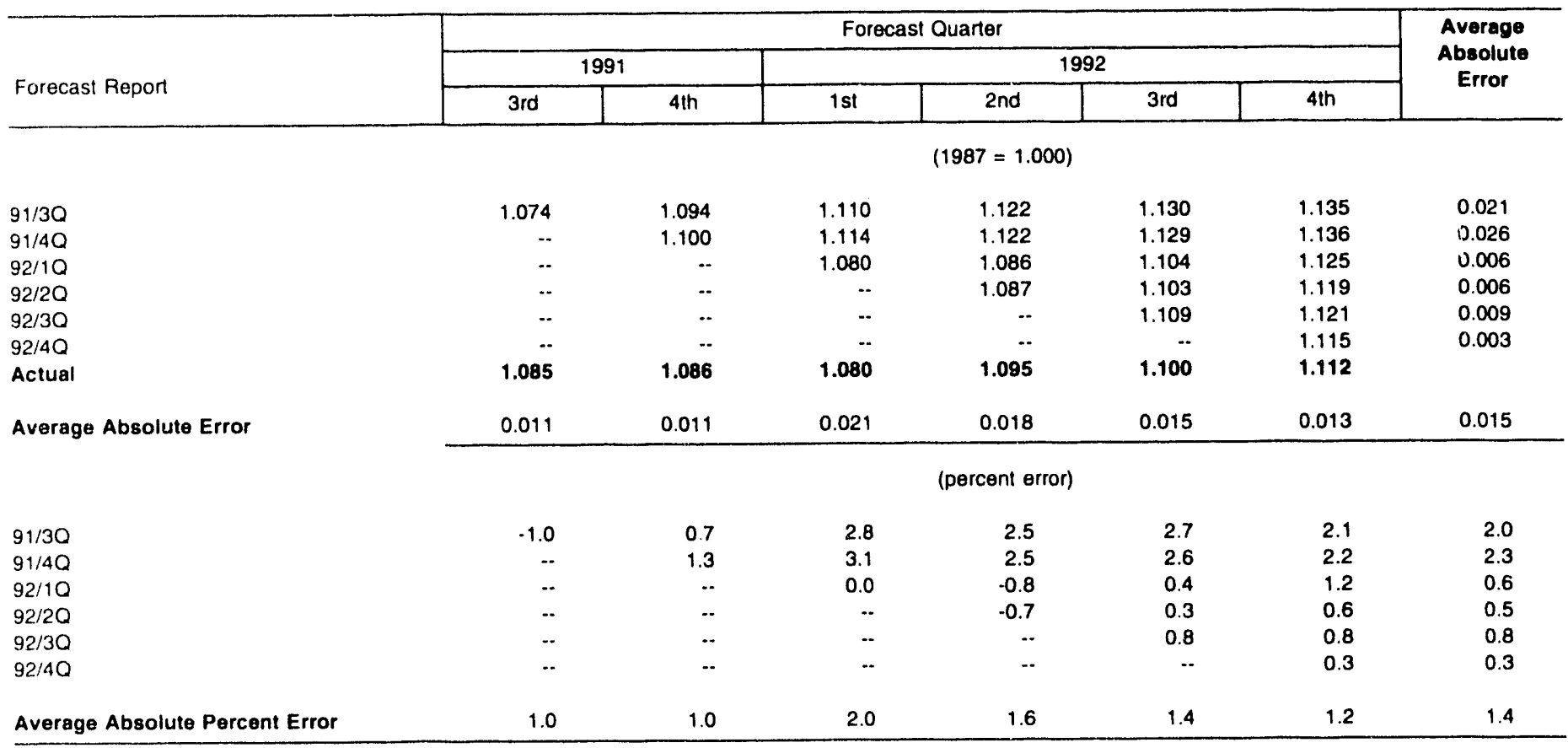

$--=$ Not applicable.

Sources: History from Federal Reserve System, Statistical Release G.12.3, various issues. Forecasts from : DRI/McGraw-Hill, Quarterly Model of U.S. Economy, CONTROL forecasts, adjusted for ElA oil price forecasts for: June 1991, September 1991, January 1992, March 1992, July 1992, and September 1992. 
Table A11. Heating Degree Days, Actual Versus Forecasts

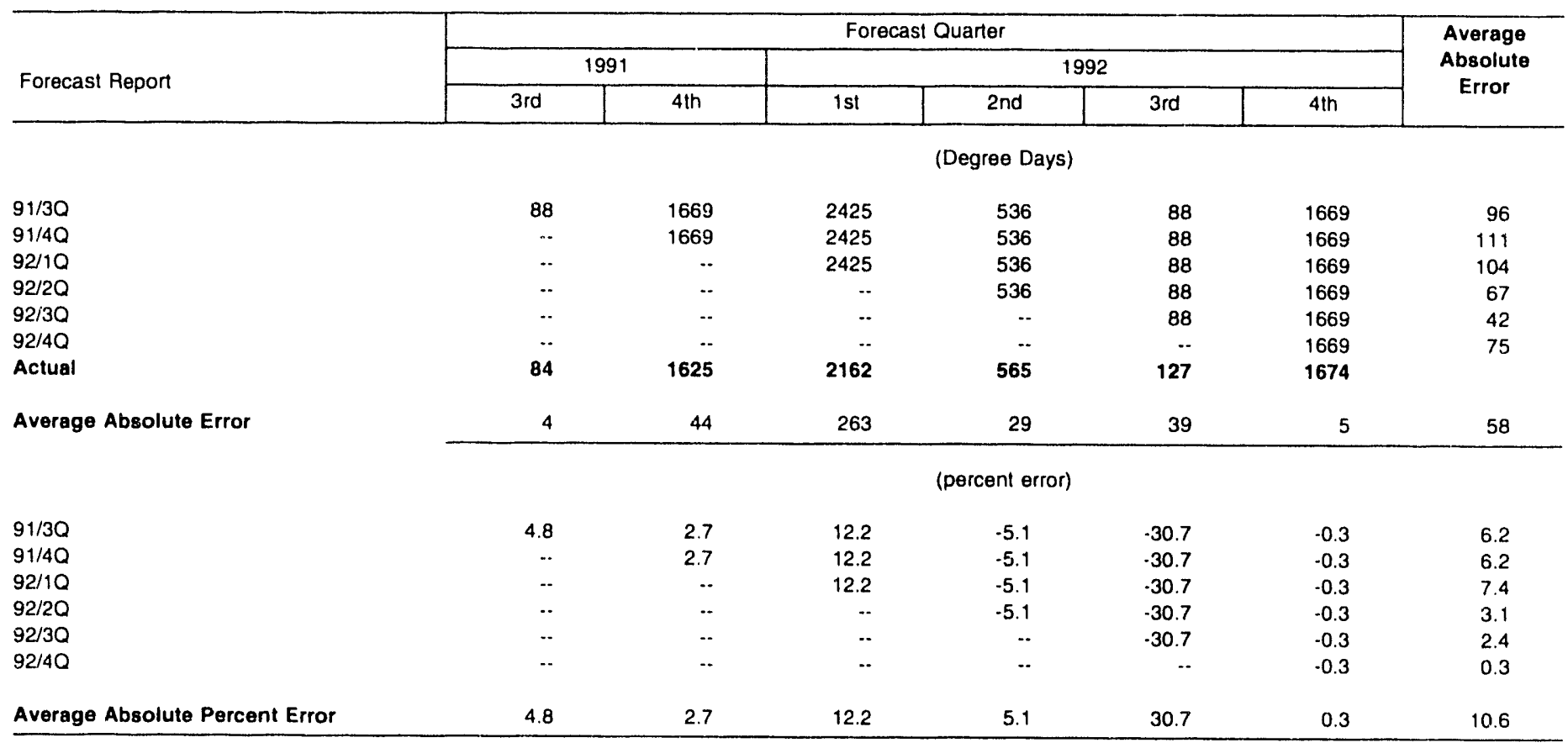

- = Not applicable.

Sources: U.S. Department of Commerce, National Oceanic and Atmospheric Administration (NOAA), Monthly State, Regional and National Heating/Cooling Degree Days, Weighted by Population; forecasts are 30-year averages of NOAA data, 1951-1980.

Table A12. Cooling Degree Days, Actual Versus Forecasts

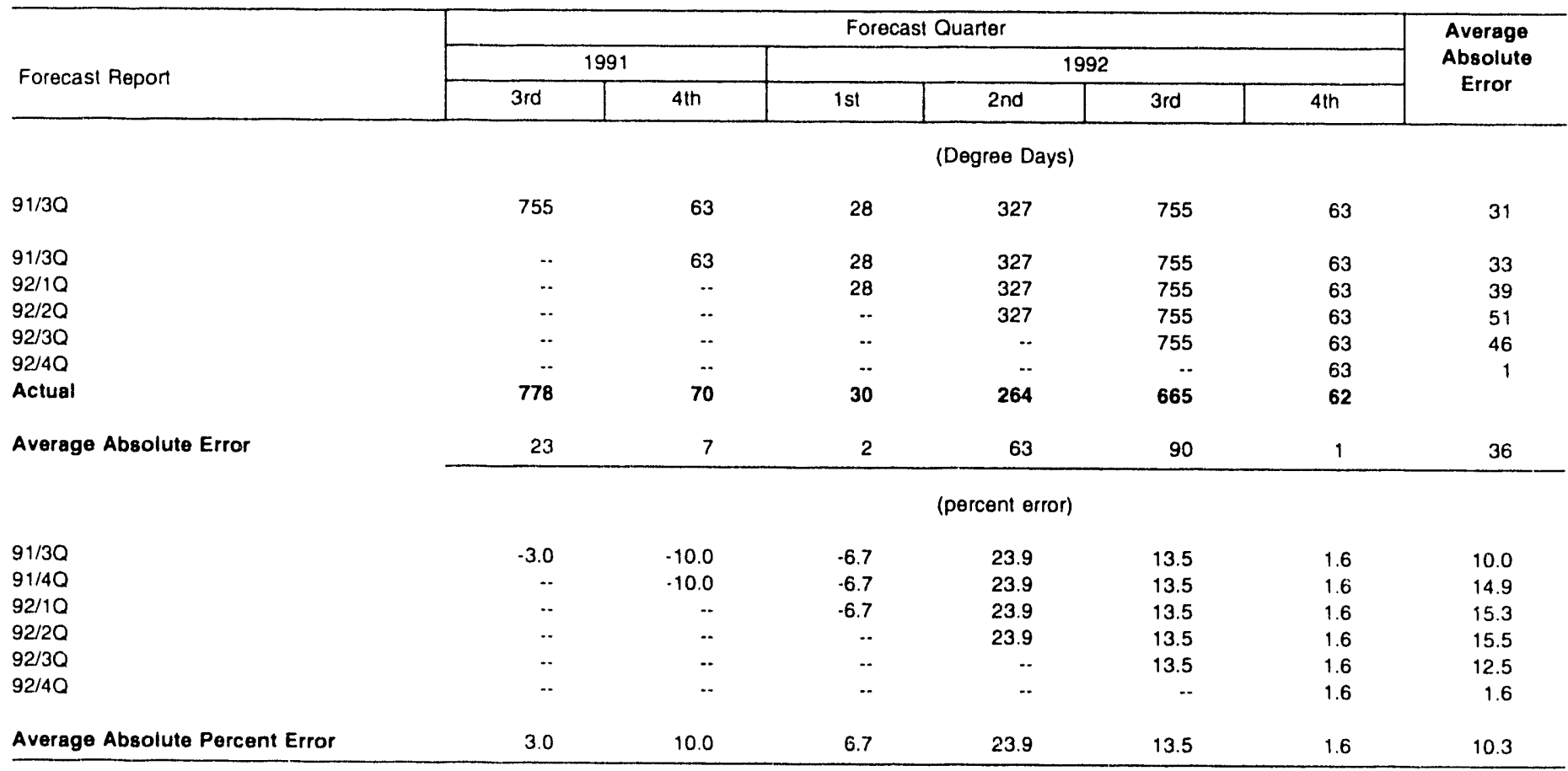

.. = Not applicable.

Sources: U.S. Department of Commerce, National Oceanic and Atmospheric Administration (NOAA), Monthly State, Regional and National Heating/Cooling Degree Days, Weighted by Population; forecasts are 30-year averages of NOAA data, 1951-1980. 
Table A13. Total Petroleum Demand (Product Supplied), Actual Versus Forecasts

\begin{tabular}{|c|c|c|c|c|c|c|c|}
\hline \multirow{3}{*}{ Forecast Report } & \multicolumn{6}{|c|}{ Forecasl Quarter } & \multirow{3}{*}{$\begin{array}{c}\text { Average } \\
\text { Absolute } \\
\text { Error }\end{array}$} \\
\hline & \multicolumn{2}{|c|}{1991} & \multicolumn{4}{|c|}{1992} & \\
\hline & 3rd & 4 th & $1 \mathrm{st}$ & 2nd & 3rd & 4th & \\
\hline & \multicolumn{7}{|c|}{ (million barrels per day) } \\
\hline $91 / 30$ & 16.48 & 17.10 & 17.20 & 16.48 & 16.73 & 17.26 & 0.27 \\
\hline $91 / 4 Q$ & .. & 17.06 & 17.28 & 16.49 & 16.71 & 17.21 & 0.24 \\
\hline $92 / 10$ & $-\cdot$ & -. & 17.13 & 16.49 & 16.73 & 17.03 & 0.28 \\
\hline $92 / 20$ & -. & $-\cdot$ & $\cdot \cdot$ & 16.52 & 16.77 & 17.19 & 0.22 \\
\hline $92 / 30$ &.- & $-\cdot$ & 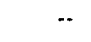 & .. & 16.90 & 17.33 & 0.10 \\
\hline $92 / 40$ & .. & $-\cdot$ & $\cdot-$ & - & .. & 17.37 & 0.11 \\
\hline Actual & 17.00 & 16.96 & 16.88 & 16.70 & 16.95 & 17.48 & \\
\hline \multirow[t]{2}{*}{ Average Absolute Error } & 0.52 & 0.12 & 0.32 & 0.21 & 0.18 & 0.25 & 0.24 \\
\hline & \multicolumn{7}{|c|}{ (percent error) } \\
\hline $91 / 30$ & -3.1 & 0.8 & 1.9 & -1.3 & -1.3 & -1.3 & 1.6 \\
\hline $91 / 40$ & -. & 0.6 & 2.4 & -1.3 & -1.4 & -1.5 & 1.4 \\
\hline $92 / 10$ & -. & -. & 1.5 & -1.3 & -1.3 & -2.6 & 1.7 \\
\hline $92 / 2 Q$ &.- & -- & $-\cdot$ & -1.1 & -1.1 & -1.7 & 1.3 \\
\hline $92 / 30$ & .. & $-\cdot$ &.. & -. & -0.3 & -0.9 & 0.6 \\
\hline $92 / 40$ & -. & -. & -- & $\cdots$ & $-\cdot$ & -0.6 & 0.6 \\
\hline Average Absolute Percent Error & 3.1 & 0.7 & 1.9 & 1.2 & 1.1 & 1.4 & 1.4 \\
\hline
\end{tabular}

-- = Not applicable.

Sources: Actual data are based on published numbers from the Energy Information Administration, Monthly Energy Review, DOE/EIA-0035(93/03); forecasts are taken from the base or mid-case scenarios of the Short-Term Energy Outlook.

Table A14. Motor Gasoline Demand (Product Supplied), Actual Versus Forecasts

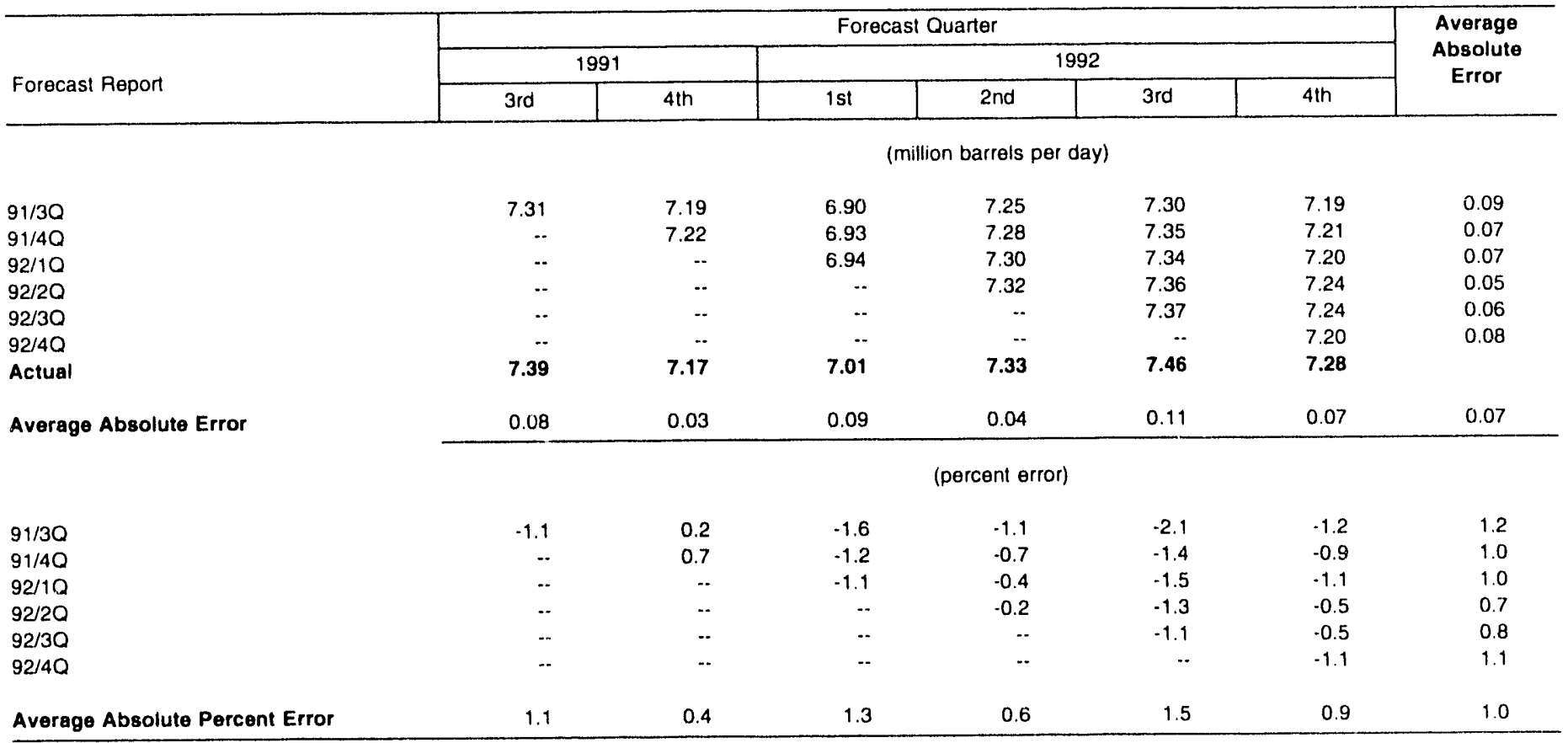

-. = Not applicable.

Sources: Actual data are based on published numbers from the Energy Information Administration, Monthly Energy Review, DOE/EIA-0035(93/03); forecasts are taken from the base or mid-case scenarios of the Short-Term Energy Outlook. 
Table A15. Distillate Fuel Demand (Product Supplied), Actual Versus Forecasts

\begin{tabular}{|c|c|c|c|c|c|c|c|}
\hline \multirow{3}{*}{ Forecast Report } & \multicolumn{6}{|c|}{ Forecast Quarter } & \multirow{3}{*}{$\begin{array}{c}\text { Average } \\
\text { Absoliste } \\
\text { Error }\end{array}$} \\
\hline & \multicolumn{2}{|c|}{1991} & \multicolumn{4}{|c|}{1992} & \\
\hline & $3 r d$ & 4 th & $1 s t$ & 2nd & $3 r d$ & 4 th & \\
\hline & \multicolumn{7}{|c|}{ (million barrels per day) } \\
\hline $91 / 3 Q$ & 2.66 & 3.21 & 3.54 & 2.93 & 2.77 & 3.29 & 0.15 \\
\hline $91 / 4 Q$ & -. & 3.20 & 3.53 & 2.91 & 2.75 & 3.27 & 0.16 \\
\hline $92 / 10$ & -- & -. & 3.48 & 2.89 & 2.72 & 3.25 & 0.13 \\
\hline $92 / 2 Q$ & $-\cdot$ & -. & -. & 2.87 & 2.72 & 3.21 & 0.07 \\
\hline $92 / 30$ & -. & -. & $\cdots$ & $\cdots$ & 2.70 & 3.22 & 0.10 \\
\hline $92 / 4 Q$ & $-\cdot$ & - & -. & $\cdots$ & .. & 3.17 & 0.08 \\
\hline Actual & 2.76 & 3.02 & 3.21 & 2.84 & 2.78 & 3.09 & \\
\hline \multirow[t]{2}{*}{ Average Absolute Error } & 0.10 & 0.19 & 0.30 & 0.06 & 0.05 & 0.14 & 0.13 \\
\hline & \multicolumn{7}{|c|}{ (percent error) } \\
\hline $91 / 3 Q$ & -3.6 & 6.3 & 10.1 & 3.2 & -0.4 & 6.4 & 5.2 \\
\hline $91 / 4 Q$ & -. & 6.0 & 9.8 & 2.5 & -1.2 & 5.8 & 5.2 \\
\hline $92 / 10$ & $\cdots$ & $\cdots$ & 8.3 & 1.8 & -2.2 & 5.1 & 4.5 \\
\hline $92 / 2 Q$ & -. & -. & $-\cdot$ & 1.1 & -2.2 & 3.8 & 2.4 \\
\hline $92 / 3 Q$ & $\cdot \cdot$ & .. & $-\cdot$ & -. & -2.9 & 4.1 & 3.6 \\
\hline $92 / 4 Q$ & -- & $-\cdot$ & $\cdots$ & $-\cdot$ & .. & 2.5 & 2.5 \\
\hline Average Absolute Percent Error & 3.6 & 6.1 & 9.4 & 2.2 & 1.8 & 4.6 & 4.3 \\
\hline
\end{tabular}

-. = Not applicable.

Sources: Actual data are based on published numbers from the Energy Information Administration, Monthly Energy Review, DOE/EIA-0035(93/03); forecasts are taken from the base or mid-case scenarios of the Short-Term Energy Outlook.

Table A16. Residual Fuel Oil Demand (Product Supplied), Actual Versus Forecasts

\begin{tabular}{|c|c|c|c|c|c|c|c|}
\hline \multirow{3}{*}{ Forecast Report } & \multicolumn{6}{|c|}{ Forecast Quarter } & \multirow{3}{*}{$\begin{array}{c}\text { Average } \\
\text { Absolute } \\
\text { Error }\end{array}$} \\
\hline & \multicolumn{2}{|c|}{1991} & \multicolumn{4}{|c|}{1992} & \\
\hline & $3 \mathrm{rd}$ & $4 \mathrm{th}$ & $1 \mathrm{st}$ & 2nd & $3 r d$ & 4 th & \\
\hline & \multicolumn{7}{|c|}{ (million barrels per day) } \\
\hline $91 / 3 Q$ & 1.00 & 1.16 & 1.26 & 0.99 & 1.01 & 1.15 & 0.05 \\
\hline $91 / 4 Q$ & $-\cdot$ & 1.16 & 1.35 & 1.01 & 1.02 & 1.17 & 0.04 \\
\hline $92 / 10$ & -. &.. & 1.32 & 1.11 & 1.04 & 1.05 & 0.09 \\
\hline $92 / 20$ & -. &.- &.- & 1.11 & 1.04 & 1.13 & 0.07 \\
\hline $92 / 30$ & .. & -. & -- &. & 1.06 & 1.17 & 0.07 \\
\hline $92 / 4 Q$ & $-\cdot$ & -. & -. & .. & -- & 1.18 & 0.02 \\
\hline Actual & 1.14 & 1.16 & 1.26 & 1.03 & 0.93 & 1.16 & \\
\hline \multirow[t]{2}{*}{ Average Absolute Error } & 0.14 & 0.00 & 0.05 & 0.06 & 0.11 & 0.03 & 0.06 \\
\hline & \multicolumn{7}{|c|}{ (percent error) } \\
\hline $91 / 30$ & -12.6 & 0.2 & 0.1 & -3.5 & 8.8 & .0 .7 & 4.1 \\
\hline $91 / 4 \mathrm{Q}$ & -. & 0.2 & 7.2 & -1.6 & 9.9 & 1.0 & 3.9 \\
\hline $92 / 10$ & -. & .. & 4.8 & 8.2 & 12.1 & -9.3 & 8.4 \\
\hline $92 / 2 \mathrm{Q}$ & -- & -. & -- & 8.2 & 12.1 & -2.4 & 7.2 \\
\hline $92 / 3 Q$ & -- & -. & -. &.. & 14.2 & 1.0 & 6.9 \\
\hline $92 / 4 Q$ & -- & $-\cdot$ & -- & -. & - & 1.9 & 1.9 \\
\hline Average Absolute Percent Error & 12.6 & 0.2 & 4.1 & 5.4 & 11.4 & 2.7 & 5.7 \\
\hline
\end{tabular}

-. = Not applicable.

Sources: Actual data are based on published numbers from the Energy Information Administration, Monthly Energy Review, DOE/EIA-0035(92/03); fcrecasts are taken from the base or mid-case scenarios of the Short-Term Energy Outlook. 
Table A17. Jet Fuel Demand (Product Supplied), Actual Versus Forecasts

\begin{tabular}{|c|c|c|c|c|c|c|c|}
\hline \multirow{3}{*}{ Forecast Report } & \multicolumn{6}{|c|}{ Forecast Quarter } & \multirow{3}{*}{$\begin{array}{c}\text { Average } \\
\text { Absolute } \\
\text { Error }\end{array}$} \\
\hline & \multicolumn{2}{|c|}{1991} & \multicolumn{4}{|c|}{1992} & \\
\hline & 3 rd & 4 ih & $1 s t$ & 2nd & 3rd & 4th & \\
\hline & & & & arrels $p$ & & & \\
\hline $91 / 3 Q$ & 1.40 & 1.49 & 1.48 & 1.43 & 1.47 & 1.54 & 0.05 \\
\hline $91 / 4 Q$ & -. & 1.50 & 1.50 & 1.50 & 1.42 & 1.48 & 0.06 \\
\hline $92 / 10$ & -- & $\cdots$ & 1.46 & 1.39 & 1.48 & 1.53 & 0.02 \\
\hline $92 / 2 Q$ & -. & -- & -- & 1.42 & 1.52 & 1.56 & 0.04 \\
\hline $92 / 30$ & $\cdots$ & $-\cdot$ & $\cdot-$ & $\cdots$ & 1.57 & 1.61 & 0.09 \\
\hline $92 / 40$ & $-\cdot$ & $\cdots$ & -- & $\cdot \cdot$ & -. & 1.51 & 0.01 \\
\hline Actual & 1.52 & 1.48 & 1.41 & 1.39 & 1.49 & 1.52 & \\
\hline \multirow[t]{2}{*}{ Average Absolute Error } & 0.12 & 0.01 & 0.07 & 0.05 & 0.04 & 0.04 & 0.05 \\
\hline & \multicolumn{7}{|c|}{ (percent error) } \\
\hline $91 / 30$ & -7.8 & 0.4 & 4.8 & 3.1 & -1.0 & 1.3 & 3.1 \\
\hline $91 / 40$ & -- & 1.1 & 6.2 & 8.1 & -4.4 & -2.6 & 4.4 \\
\hline $92 / 10$ & -- & $\cdots$ & 3.4 & 0.2 & -0.3 & 0.7 & 1.1 \\
\hline $92 / 2 Q$ & $-\cdot$ & $\cdot-$ & -. & 2.4 & 2.4 & 2.6 & 2.5 \\
\hline $92 / 3 Q$ & $\cdots$ & $-\cdot$ & .. & $-\cdot$ & 5.7 & 5.9 & 5.8 \\
\hline $92 / 4 Q$ & $\cdots$ & $\cdots$ & $\cdots$ & $\cdots$ & $\cdots$ & -0.7 & 0.7 \\
\hline Average Absolute Percent Error & 7.8 & 0.7 & 4.8 & 3.5 & 2.8 & 2.3 & 3.1 \\
\hline
\end{tabular}

$--=$ Not applicable.

Sources: Actual data are based on published numbers from the Energy Information Administration, Monthly Energy Review, DOE/EIA-0035(93/03); forecasts are taken from the base or mid-case scenarios of the Short-Term Energy Outlook.

Table A18. Other Petroleum Products Supplied, Actual Versus Forecasts

\begin{tabular}{|c|c|c|c|c|c|c|c|}
\hline \multirow{3}{*}{ Forecast Report } & \multicolumn{6}{|c|}{ Forecast Quarter } & \multirow{3}{*}{$\begin{array}{c}\text { Average } \\
\text { Absolute } \\
\text { Error }\end{array}$} \\
\hline & \multicolumn{2}{|c|}{1991} & \multicolumn{4}{|c|}{1992} & \\
\hline & 3rd & 4 th & $1 \mathrm{st}$ & 2nd & 3rd & 4 th & \\
\hline & \multicolumn{7}{|c|}{ (million barrels per day) } \\
\hline $91 / 30$ & 4.11 & 4.06 & 4.01 & 3.89 & 4.17 & 4.10 & 0.14 \\
\hline $91 / 4 Q$ & .. & 3.98 & 3.98 & 3.87 & 4.11 & 4.01 & 0.20 \\
\hline $92 / 10$ & .. & -. & 3.93 & 3.79 & 4.15 & 3.99 & 0.24 \\
\hline $92 / 20$ & -- & -. & .. & 3.80 & 4.13 & 4.05 & 0.29 \\
\hline $92 / 30$ & $-\cdot$ & $-\cdot$ & -. & $-\cdot$ & 4.20 & 4.10 & 0.22 \\
\hline $92 / 4 Q$ & $\cdot \cdot$ & $\cdot-$ & .- & -. & -. & 4.31 & 0.12 \\
\hline Actual & 4.19 & 4.13 & 3.99 & 4.12 & 4.30 & 4.43 & \\
\hline \multirow[t]{2}{*}{ Average Absolute Error } & 0.07 & 0.11 & 0.03 & 0.28 & 0.15 & 0.34 & 0.20 \\
\hline & \multicolumn{7}{|c|}{ (percent error) } \\
\hline $91 / 3 Q$ & -1.8 & -1.6 & 0.6 & -5.6 & -3.0 & -7.5 & 3.4 \\
\hline $91 / 4 Q$ &.- & -3.5 & -0.2 & -6.1 & -4.4 & -9.7 & 4.8 \\
\hline $92 / 1 Q$ & 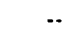 & $-\cdot$ & -1.4 & -8.0 & -3.5 & -10.0 & 5.8 \\
\hline $92 / 2 Q$ & -- & $-\cdot$ & -- & -7.8 & -4.0 & -8.6 & 6.8 \\
\hline $92 / 3 Q$ & .. & -- & -. & -. & -2.3 & -7.5 & 5.0 \\
\hline $92 / 4 Q$ & $\cdot-$ & 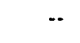 & -. & -. & $-\cdot$ & -2.8 & 2.8 \\
\hline Average Absolute Percent Error & 1.8 & 2.5 & 0.7 & 6.9 & 3.5 & 7.7 & 4.8 \\
\hline
\end{tabular}

.. = Not applicable.

Sources: Actual data are based on published numbers from the Energy Information Administration, Monthly Energy Review, DOE/EIA-0035(93/03); forecasts are taken from the base or mid-case scenarios of the Short-Term Energy Outlook. 
Table A19. Domestic Crude Oil Production, Actual Versus Forecasts

\begin{tabular}{|c|c|c|c|c|c|c|c|}
\hline \multirow{3}{*}{ Forecast Report } & \multicolumn{6}{|c|}{ Forecast Quarter } & \multirow{3}{*}{$\begin{array}{c}\text { Average } \\
\text { Absolute } \\
\text { Error }\end{array}$} \\
\hline & \multicolumn{2}{|c|}{1991} & \multicolumn{4}{|c|}{1992} & \\
\hline & 3rd & 4th & $1 \mathrm{st}$ & 2nd & 3rd & 4 th & \\
\hline & & & & arrels & & & \\
\hline $91 / 30$ & 7.30 & 7.30 & 7.26 & 7.11 & 6.98 & 7.00 & 0.06 \\
\hline $91 / 40$ & .. & 7.29 & 7.20 & 7.07 & 6.92 & 6.98 & 0.10 \\
\hline $92 / 10$ & .. & .- & 7.29 & 7.17 & 7.05 & 7.10 & 0.03 \\
\hline $92 / 2 Q$ & .. & $\cdots$ & -. & 7.17 & 7.03 & 7.07 & 0.01 \\
\hline $92 / 30$ & .. & .. & -. & -. & 7.07 & 7.12 & 0.05 \\
\hline $92 / 4 Q$ & -. & .. & - & -. & $\cdots$ & 7.16 & 0.09 \\
\hline Actual & 7.34 & 7.36 & 7.35 & 7.18 & 7.01 & 7.07 & \\
\hline \multirow[t]{2}{*}{ Average Absolute Error } & 0.04 & 0.06 & 0.10 & 0.05 & 0.05 & 0.05 & 0.06 \\
\hline & \multicolumn{7}{|c|}{ (percent error) } \\
\hline $91 / 30$ & -0.6 & -0.7 & -1.2 & -1.0 & -0.5 & -1.0 & 0.8 \\
\hline $91 / 4 Q$ & .- & -0.9 & -2.0 & -1.5 & -1.3 & -1.3 & 1.4 \\
\hline $92 / 1 Q$ & $\cdots$ & -. & -0.8 & -0.1 & 0.5 & 0.4 & 0.5 \\
\hline $92 / 20$ & $\cdots$ & -- & -. & -0.1 & 0.2 & 0.0 & 0.1 \\
\hline $92 / 30$ & -. & .. & -- & -. & 0.8 & 0.7 & 0.7 \\
\hline $92 / 4 Q$ & $\cdots$ & -- & 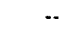 & $\cdots$ & $\cdots$ & 1.2 & 1.2 \\
\hline Average Absolute Percent Error & 0.6 & 0.8 & 1.4 & 0.7 & 0.7 & 0.8 & 0.8 \\
\hline
\end{tabular}

$-\bar{*}=$ Not applicable.

$P=$ Preliminary.

Sources: Actual data are based on published numbers from the Energy Information Administration, Monthly Energy Reviow, DOE/EIA-0035(93/03); forecasts are taken from the base or mid-case scenarios of the Short-Term Energy Outlook.

Table A20. Alaskan Crude Oil Production, Actual Versus Forecasts

\begin{tabular}{|c|c|c|c|c|c|c|c|}
\hline \multirow{3}{*}{ Forecast Report } & \multicolumn{6}{|c|}{ Forecast Quarter } & \multirow{3}{*}{$\begin{array}{c}\text { Average } \\
\text { Absolute } \\
\text { Error }\end{array}$} \\
\hline & \multicolumn{2}{|c|}{1991} & \multicolumn{4}{|c|}{1992} & \\
\hline & 3rd & 4 th & $1 \mathrm{st}$ & 2nd & 3rd & 4 th & \\
\hline & \multicolumn{7}{|c|}{ (million barrels per day) } \\
\hline $91 / 30$ & 1.73 & 1.77 & 1.75 & 1.71 & 1.65 & 1.69 & 0.02 \\
\hline $91 / 40$ &.. & 1.79 & 1.72 & 1.68 & 1.58 & 1.66 & 0.05 \\
\hline $92 / 1 Q$ & .. & .. & 1.80 & 1.74 & 1.66 & 1.71 & 0.01 \\
\hline $92 / 20$ & -. & -. & -. & 1.73 & 1.64 & 1.70 & 0.02 \\
\hline $92 / 30$ & .. & .. & .. & .. & 1.62 & 1.65 & 0.04 \\
\hline $92 / 40$ &.. & .. & -. & -. & -- & 1.71 & 0.02 \\
\hline Actual & 1.76 & 1.78 & 1.79 & 1.71 & 1.66 & 1.69 & \\
\hline \multirow[t]{2}{*}{ Average Absolute Error } & 0.03 & 0.01 & 0.04 & 0.02 & 0.03 & 0.02 & 0.03 \\
\hline & \multicolumn{7}{|c|}{ (percent error) } \\
\hline $91 / 3 Q$ & -1.9 & -0.3 & -2.5 & 0.0 & -0.8 & 0.0 & 1.0 \\
\hline $91 / 4 \mathrm{Q}$ & .. & 0.8 & -4.1 & -1.6 & -5.0 & -1.9 & 2.7 \\
\hline $92 / 10$ & -. & -. & 0.3 & 1.9 & -0.2 & 1.1 & 0.9 \\
\hline $92 / 2 Q$ & -. & $-\cdot$ & $\cdot \cdot$ & 1.3 & -1.4 & 0.5 & 1.0 \\
\hline $92 / 30$ & .. & .. & .. & -. & -2.6 & -2.5 & 2.5 \\
\hline $92 / 4 \mathrm{Q}$ & -. & $\cdots$ & -- & $\cdot \cdot$ & $-\cdot$ & 1.1 & 1.1 \\
\hline Average Absolute Percent Error & 1.9 & 0.6 & 2.3 & 1.2 & 2.0 & 1.2 & 1.5 \\
\hline
\end{tabular}

-. = Not applicable.

Sources: Actual data are based on published numbers from the Energy Information Administration, Monthly Energy Review, DOE/EIA-0035(93/03); forecasts are taken from the base or mid-case scenarios of the Short-Term Energy Outlook. 
Table A21. Lower 48 Crude Oil Production, Actual Versus Forecasts

\begin{tabular}{|c|c|c|c|c|c|c|c|}
\hline \multirow{3}{*}{ Forecast Report } & \multicolumn{6}{|c|}{ Forecast Quarter } & \multirow{3}{*}{$\begin{array}{c}\text { Average } \\
\text { Absolute } \\
\text { Error }\end{array}$} \\
\hline & \multicolumn{2}{|c|}{1991} & \multicolumn{4}{|c|}{1992} & \\
\hline & 3rd & 4 th & $1 \mathrm{st}$ & 2nd & 3rd & 4 th & \\
\hline & \multicolumn{7}{|c|}{ (million barrels per day) } \\
\hline $91 / 30$ & 5.57 & 5.53 & 5.50 & 5.41 & 5.34 & 5.31 & 0.04 \\
\hline $91 / 4 Q$ & .. & 5.49 & 5.47 & 5.39 & 5.33 & 5.31 & 0.07 \\
\hline $92 / 1 Q$ & .. & -. & 5.49 & 5.43 & 5.39 & 5.39 & 0.04 \\
\hline $92 / 2 Q$ & .. & -- & -. & 5.44 & 5.39 & 5.38 & 0.02 \\
\hline $92 / 3 Q$ & .. & -- & -. & -. & 5.45 & 5.45 & 0.08 \\
\hline $92 / 40$ & .. & -. & .. & -. & -- & 5.45 & 0.07 \\
\hline Actual & 5.58 & 5.58 & 5.56 & 5.47 & 5.35 & 5.38 & \\
\hline \multirow[t]{2}{*}{ Average Absolute Error } & 0.01 & 0.07 & 0.07 & 0.05 & 0.04 & 0.05 & 0.05 \\
\hline & \multicolumn{7}{|c|}{ (percent error) } \\
\hline $91 / 30$ & -0.2 & -0.9 & -1.0 & -1.1 & -0.2 & -1.3 & 0.8 \\
\hline $91 / 4 Q$ & .. & -1.6 & -1.5 & -1.5 & -0.4 & -1.3 & 1.3 \\
\hline $92 / 10$ & $-\cdot$ & $-\cdot$ & -0.2 & -0.7 & 0.7 & 0.2 & 0.7 \\
\hline $92 / 2 Q$ & .. & .. & -. & -0.5 & 0.7 & 0.0 & 0.4 \\
\hline $92 / 30$ & -- & .. & -. & $\cdot \cdot$ & 1.8 & 1.3 & 1.6 \\
\hline $92 / 4 Q$ & -. & -. & -- & -. & -- & 1.3 & 1.3 \\
\hline Average Absolute Percent Error & 0.2 & 1.3 & 1.2 & 1.0 & 0.8 & 0.9 & 0.9 \\
\hline
\end{tabular}

.. = Not applicable.

Sources: Actual data are based on published numbers from the Energy Infurmation Administration, Monthly Energy Review, DOE/EIA-0035(93/03); forecasts are taken from the base or mid-case scenarios of the Short-Term Energy Outlook.

Table A22. Net Oil Imports, Actual Versus Forecasts (Excluding SPR)

\begin{tabular}{|c|c|c|c|c|c|c|c|}
\hline \multirow{3}{*}{ Forecast Report } & \multicolumn{6}{|c|}{ Forecast Quarter } & \multirow{3}{*}{$\begin{array}{c}\text { Average } \\
\text { Absolute } \\
\text { Error }\end{array}$} \\
\hline & \multicolumn{2}{|c|}{1991} & \multicolumn{4}{|c|}{1992} & \\
\hline & $3 r d$ & 4 th & $1 \mathrm{st}$ & 2nd & 3rd & 4 th & \\
\hline & \multicolumn{7}{|c|}{ (million barrels per day) } \\
\hline $91 / 30$ & 6.89 & 6.94 & 7.02 & 7.34 & 7.48 & 7.28 & 0.40 \\
\hline $91 / 4 \mathrm{Q}$ & .. & 6.84 & 7.04 & 7.41 & 7.55 & 7.31 & 0.43 \\
\hline $92 / 10$ & .. & $-\cdot$ & 6.79 & 7.18 & 7.51 & 7.15 & 0.27 \\
\hline $92 / 2 \mathrm{Q}$ & -. & -. & -. & 7.33 & 7.56 & 7.44 & 0.31 \\
\hline $92 / 30$ &.- & -. & -. & $-\cdot$ & 7.54 & 7.50 & 0.28 \\
\hline $92 / 4 \mathrm{Q}$ & .. & $-\cdot$ & -. & -. & -. & 7.31 & 0.28 \\
\hline Actual & 7.22 & 6.45 & 6.16 & 6.93 & 7.44 & 7.03 & \\
\hline \multirow[t]{2}{*}{ Average Absolute Error } & 0.33 & 0.44 & 0.79 & 0.38 & 0.09 & 0.30 & 0.35 \\
\hline & \multicolumn{7}{|c|}{ (percent error) } \\
\hline $91 / 30$ & -4.6 & 7.6 & 13.9 & 5.9 & 0.5 & 3.5 & 5.7 \\
\hline $91 / 4 \mathrm{Q}$ & $-\cdot$ & 6.0 & 14.2 & 6.9 & 1.5 & 4.0 & 6.3 \\
\hline $92 / 10$ &.. & -- & 10.2 & 3.6 & 0.9 & 1.7 & 3.8 \\
\hline $92 / 20$ & -. & .. & $\cdot \cdot$ & 5.7 & 1.6 & 5.8 & 4.3 \\
\hline $92 / 30$ &.- & .- & -. & -. & 1.3 & 6.7 & 3.9 \\
\hline $92 / 4 Q$ & $\cdot \cdot$ & -. & -. &.. & -. & 4.0 & 4.0 \\
\hline Average Absolute Percent Error & 4.6 & 6.8 & 12.8 & 5.5 & 1.2 & 4.3 & 5.2 \\
\hline
\end{tabular}

-. = Not applicable.

SPR = Strategic Petroleum Reserve.

Sources: Actual data are based on published numbers from the r.nergy information Administration, Monthly Energy Review, DOE/EIA-0035(93/03); forecasts are taken from the base or mid-case scenarios of the Short-Term Energy Outlook. 
Table A23. Total Petroleum Stocks, Actual Versus Forecasts (Excluding SPR)

\begin{tabular}{|c|c|c|c|c|c|c|c|}
\hline \multirow{3}{*}{ Forecast Report } & \multicolumn{6}{|c|}{ Forecast Quarter } & \multirow{3}{*}{$\begin{array}{c}\text { Average } \\
\text { Absolute } \\
\text { Error }\end{array}$} \\
\hline & \multicolumn{2}{|c|}{1991} & \multicolumn{4}{|c|}{1992} & \\
\hline & 3rd & 4 th & $1 s t$ & 2nd & 3rd & 4th & \\
\hline & & & & on barr & & & \\
\hline $91 / 30$ & 1089 & 1061 & 1025 & 1071 & 1099 & 1069 & 28 \\
\hline $91 / 4 Q$ & .. & 1063 & 1018 & 1062 & 1089 & 1061 & 26 \\
\hline $92 / 10$ & -. & .. & 1017 & 1048 & 1081 & 1067 & 25 \\
\hline $92 / 2 \mathrm{Q}$ & -. & .. & -- & 1034 & 1070 & $106 a$ & 20 \\
\hline $92 / 30$ & .. & .. & .. & .. & 1074 & 1070 & 32 \\
\hline $92 / 4 Q$ & .. & .. & -. & -. & .. & 1063 & 46 \\
\hline Actual & 1094 & 1048 & 1001 & 1033 & 1064 & 1017 & \\
\hline \multirow[t]{2}{*}{ Average Absolute Error } & 5 & 14 & 19 & 21 & 19 & 49 & 27 \\
\hline & \multicolumn{7}{|c|}{ (percent error) } \\
\hline $91 / 30$ & -0.5 & 1.2 & 2.4 & 3.7 & 3.3 & 5.1 & 2.7 \\
\hline $91 / 40$ & .. & 1.4 & 1.7 & 2.8 & 2.4 & 4.3 & 2.5 \\
\hline $92 / 10$ & -- & -. & 1.6 & 1.5 & 1.6 & 4.9 & 2.4 \\
\hline $92 / 20$ & .. & .. & .. & 0.1 & 0.6 & 5.0 & 1.9 \\
\hline $92 / 30$ & .. & -. & .. & -. & 1.0 & 5.2 & 3.1 \\
\hline $92 / 40$ & -. & -. & .. & .. & -- & 4.5 & 4.5 \\
\hline Average Absolute Percent Error & 0.5 & 1.3 & 1.9 & 2.0 & 1.8 & 4.9 & 2.6 \\
\hline
\end{tabular}

-- = Not applicable.

SPR = Strategic Petroleum Reserve.

Sources: Actual data are based on published numbers from the Energy Information Administration, Monthly Energy Review, DOE/EIA-0035(93/03); forecasts are taken from the base or mid-case scenarios of the Short-Term Energy Outlook.

Table A24. Natural Gas Demand, Actual Versus Forecasts

\begin{tabular}{|c|c|c|c|c|c|c|c|}
\hline \multirow{3}{*}{ Forecast Report } & \multicolumn{6}{|c|}{ Forecast Quarter } & \multirow{3}{*}{$\begin{array}{c}\text { Average } \\
\text { Absolute } \\
\text { Error }\end{array}$} \\
\hline & \multicolumn{2}{|c|}{1991} & \multicolumn{4}{|c|}{1992} & \\
\hline & 3rd & 4 th & $1 \mathrm{st}$ & 2nd & 3rd & 4 th & \\
\hline & & & & cubic & & & \\
\hline $91 / 30$ & 3.53 & 4.93 & 6.20 & 4.45 & 3.67 & 5.03 & 0.16 \\
\hline $91 / 4 Q$ & -. & 4.94 & 6.31 & 4.53 & 3.76 & 5.03 & 0.15 \\
\hline $92 / 1 Q$ & -. & .. & 6.44 & 4.37 & 3.84 & 5.02 & 0.13 \\
\hline $92 / 20$ & .. & -. & -. & 4.40 & 3.94 & 5.26 & 0.02 \\
\hline $92 / 30$ & -. & .. & -. & .. & 4.02 & 5.38 & 0.13 \\
\hline $92 / 4 \mathrm{Q}$ & .. & .. & .- & .. & -. & 5.17 & 0.07 \\
\hline Actual & 3.79 & 5.12 & 6.21 & 4.39 & 3.89 & ${ }^{P} 5.24$ & \\
\hline \multirow[t]{2}{*}{ Average Absolute Error } & 0.26 & 0.19 & 0.11 & 0.06 & 0.12 & 0.15 & 0.13 \\
\hline & \multicolumn{7}{|c|}{ (percent error) } \\
\hline $91 / 30$ & -7.0 & -3.8 & -0.1 & 1.3 & -5.7 & -4.1 & 3.3 \\
\hline $91 / 40$ & -. & -3.6 & 1.7 & 3.1 & -3.3 & -4.1 & 3.1 \\
\hline $92 / 10$ & -. & .. & 3.8 & -0.5 & -1.3 & -4.3 & 2.7 \\
\hline $92 / 2 Q$ & -. & .. & -. & 0.2 & 1.3 & 0.3 & 0.6 \\
\hline $92 / 3 Q$ & -- & .. & .. & -. & 3.3 & 2.6 & 2.9 \\
\hline $92 / 40$ & $-\cdot$ & -. & $\cdot-$ & .. & -. & -1.4 & 1.4 \\
\hline Average Absolute Percent Error & 7.0 & 3.7 & 1.8 & 1.3 & 3.0 & 2.8 & 2.7 \\
\hline
\end{tabular}

\footnotetext{
$--=$ Not applicable.
}

${ }^{P}=$ Preliminary.

Sources: Actual data are based on published numbers from the Energy Information Administration, Monthly Energy Review, DOE/EIA-0035(93/03); forecasts are taken from the base or mid-case scenarios of the Short-Term Energy Outlook. 
Table A25. Natural Gas Production, Actual Versus Forecasts

\begin{tabular}{|c|c|c|c|c|c|c|c|}
\hline \multirow{3}{*}{ Forecast Report } & \multicolumn{6}{|c|}{ Forecast Quarter } & \multirow{3}{*}{$\begin{array}{c}\text { Average } \\
\text { Absolute } \\
\text { Error }\end{array}$} \\
\hline & \multicolumn{2}{|c|}{1991} & \multicolumn{4}{|c|}{1992} & \\
\hline & 3rd & 4 th & $1 \mathrm{st}$ & 2 nd & 3rd & 4 th & \\
\hline & & & & cubic & & & \\
\hline $91 / 3 Q$ & 4.10 & 4.52 & 4.60 & 4.35 & 4.15 & 4.56 & 0.11 \\
\hline $91 / 4 \mathrm{Q}$ & $-\cdot$ & 4.53 & 4.64 & 4.35 & 4.30 & 4.56 & 0.09 \\
\hline $92 / 1 \mathrm{Q}$ &.. & & 4.49 & 4.39 & 4.33 & 4.56 & 0.02 \\
\hline $92 / 20$ & $\cdots$ & -. & $-\cdot$ & 4.31 & 4.37 & 4.65 & 0.03 \\
\hline $92 / 30$ &.- & $\cdot-$ & .. & -. & 4.57 & 4.90 & 0.26 \\
\hline $92 / 4 \mathrm{Q}$ & $-\cdot$ & $-\cdot$ & $\cdots$ & $-\cdot$ & -- & 4.83 & 0.22 \\
\hline Actual & 4.21 & 4.65 & 4.48 & 4.30 & 4.34 & 4.61 & \\
\hline \multirow[t]{2}{*}{ Average Absolute Error } & 0.11 & 0.12 & 0.10 & 0.04 & 0.10 & 0.12 & 0.10 \\
\hline & \multicolumn{7}{|c|}{ (percent error) } \\
\hline $91 / 30$ & -2.7 & -2.8 & 2.7 & 1.8 & -4.4 & -1.1 & 2.6 \\
\hline $91 / 40$ & -- & -2.6 & 3.5 & 1.6 & -1.0 & -1.1 & 2.0 \\
\hline $92 / 10$ & -. & -- & 0.2 & 0.2 & -0.3 & .1 .1 & 0.5 \\
\hline $92 / 20$ & -. & -. & -. & 0.4 & 0.6 & 0.8 & 0.6 \\
\hline $92 / 30$ & .. & $\cdot$. & -. & -. & 5.3 & 6.2 & 5.8 \\
\hline $92 / 40$ & -. & $\cdot \cdot$ & $\cdot \cdot$ & $\cdots$ & $\cdots$ & 4.7 & 4.7 \\
\hline Average Absolute Percent Error & 2.7 & 2.7 & 2.1 & 1.0 & 2.3 & 2.5 & 2.1 \\
\hline
\end{tabular}

.. = Not applicable.

${ }^{\mu}=$ Preliminary.

Sources: Actual data are based on published numbers from the Energy Information Administration, Monthly Energy Review, DOE/EIA-0035(93/03); torecasts are taken from the base or mid-case scenarios of the Short-Term Enargy Outlook.

Table A26. Domestic Coal Demand, Actual Versus Forecasts

\begin{tabular}{|c|c|c|c|c|c|c|c|}
\hline \multirow{3}{*}{ Forecast Report } & \multicolumn{6}{|c|}{ Forecast Quarter } & \multirow{3}{*}{$\begin{array}{c}\text { Average } \\
\text { Absolute } \\
\text { Error }\end{array}$} \\
\hline & \multicolumn{2}{|c|}{1991} & \multicolumn{4}{|c|}{1992} & \\
\hline & 3rd & 4 th & $1 \mathrm{sl}$ & 2 nd & 3rd & 4 th & \\
\hline & \multicolumn{7}{|c|}{ (million short tons) } \\
\hline $91 / 30$ & 241 & 226 & 231 & 218 & 248 & 231 & 5 \\
\hline $91 / 4 Q$ & -. & 227 & 231 & 223 & 249 & 234 & 8 \\
\hline $92 / 1 \mathrm{Q}$ & -. & $\cdot \cdot$ & 229 & 210 & 239 & 230 & 3 \\
\hline $92 / 2 \mathrm{O}$ &.. & $\cdot \cdot$ & .. & 209 & 237 & 229 & 3 \\
\hline $92 / 30$ & -. &.$\cdot$ & .. & .. & 238 & 228 & 3 \\
\hline $92 / 40$ & .. &.. & .. & .. & -. & 229 & 3 \\
\hline Actual & 238 & 221 & 225 & 212 & 242 & 227 & \\
\hline \multirow[t]{2}{*}{ Average Absolute Error } & 3 & 5 & 5 & 6 & 5 & 3 & 4 \\
\hline & \multicolumn{7}{|c|}{ (percent error) } \\
\hline $91 / 30$ & 1.1 & 2.2 & 2.7 & 2.7 & 2.7 & 1.8 & 2.1 \\
\hline $91 / 4 \mathrm{Q}$ & .. & 2.7 & 2.7 & 5.1 & 3.1 & 3.1 & 3.0 \\
\hline $92 / 10$ & -. &.. & 1.8 & -1.0 & -1.0 & 1.3 & 1.3 \\
\hline $92 / 20$ & .. & $\cdot-$ & -. & -1.5 & -1.9 & 0.9 & 1.5 \\
\hline $92 / 30$ & .. & .. & .. & .. & -1.4 & 0.4 & 1.1 \\
\hline $92 / 40$ & $\cdots$ & $\cdot \cdot$ & .. & -. & .. & 0.9 & 0.9 \\
\hline Average Absolute Percent Error & 1.1 & 2.4 & 2.4 & 2.6 & 2.0 & 1.4 & 1.9 \\
\hline
\end{tabular}

.. = Not applicable.

Sources: Actual data are baseo on published numbers from the Energy Information Administration, Quarterly Coal Report, DOE/EIA-0121(92/4Q); forecasts are taken frum the base or mid-case scenarios of the Short-Term Energy Outlook. 
Table A27. Coal Production, Actual Versus Forecasts

\begin{tabular}{|c|c|c|c|c|c|c|c|}
\hline \multirow{3}{*}{ Forecast Report } & \multicolumn{6}{|c|}{ Forecast Quarter } & \multirow{3}{*}{$\begin{array}{c}\text { Average } \\
\text { Absolute } \\
\text { Error }\end{array}$} \\
\hline & \multicolumn{2}{|c|}{1991} & \multicolumn{4}{|c|}{1992} & \\
\hline & 3 rd & 4th & $15 t$ & $2 \mathrm{nd}$ & $3 r d$ & 4 th & \\
\hline & \multicolumn{7}{|c|}{ (million short tons) } \\
\hline $91 / 30$ & 248 & 258 & 255 & 258 & 253 & 260 & 6 \\
\hline $91 / 40$ & -. & 258 & 259 & 251 & 255 & 266 & 7 \\
\hline $92 / 10$ & .. & .. & 254 & 246 & 253 & 263 & 5 \\
\hline $92 / 20$ & .. & .. & $\cdot \cdot$ & 243 & 255 & 261 & 5 \\
\hline $92: 30$ & .. & .. & .. & .. & 259 & 265 & 11 \\
\hline $93 / 40$ & .. & .. & .. & .. & .. & 257 & 7 \\
\hline Actual & 251 & 253 & 257 & 243 & 250 & 251 & \\
\hline \multirow[t]{2}{*}{ Average Absolute Error } & 3 & 5 & 2 & 6 & 5 & 12 & 7 \\
\hline & \multicolumn{7}{|c|}{ (percent error) } \\
\hline $91 / 30$ & $\cdot 14$ & 2.1 & .0 .7 & 6.0 & 1.3 & 3.8 & 2.5 \\
\hline $51 / 40$ & .. & 2.1 & 0.9 & 3.1 & 2.1 & 6.2 & 2.9 \\
\hline $92 / 10$ & .. & .. & -1.1 & 1.1 & 1.3 & 5.0 & 2.1 \\
\hline $92 / 20$ & .. & .. & .. & -0.2 & 2.1 & 4.2 & 2.2 \\
\hline $92 / 30$ & .. & .. & .. & .. & 3.3 & 5.8 & 4.6 \\
\hline $92 / 40$ & -. & .. & .. & .. & .- & 2.6 & 2.6 \\
\hline Average Ausolute Percent Error & 1.4 & 2.1 & 0.9 & 2.6 & 2.0 & 4.6 & 2.7 \\
\hline
\end{tabular}

.. = Not applicable

Sources: Actual data are based on published numbers from the Energy Information Administration, Quarterly Coal Report, DOE/EIA-0121(92/4Q); inrecasts are taken from the base or mid-case scenarios of the Short-Term Energy Outlook.

Table A28. Total Electricity Sales, Actual Versus Forecasts

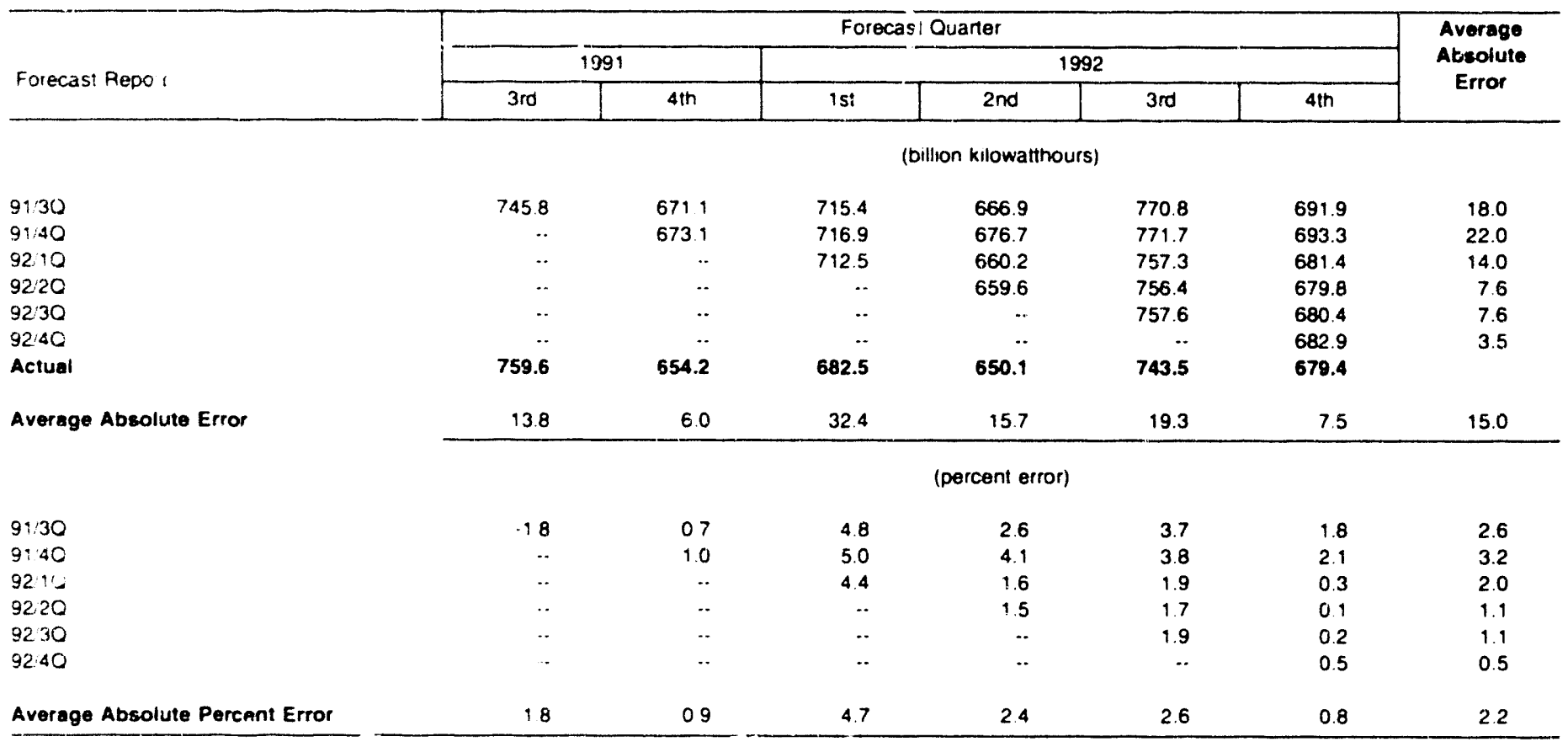

. = Not applicable.

Sources Actual data are based on pubished numbers from the Energy Information Administration, Monthly Energy Review, DOE/EIA-0035(93/03); forecasts are taken from the base or mid-case scenarios of the Short-Term Energy Outlook. 
Table A29. Residential Electricity Sales, Actual Versus Forecasts

\begin{tabular}{|c|c|c|c|c|c|c|c|}
\hline \multirow{3}{*}{ Forecast Repont } & \multicolumn{6}{|c|}{ Forecast Quarter } & \multirow{3}{*}{$\begin{array}{c}\text { Average } \\
\text { Absolute } \\
\text { Error }\end{array}$} \\
\hline & \multicolumn{2}{|c|}{1991} & \multicolumn{4}{|c|}{1992} & \\
\hline & 3rd & 4 th & $1 \mathrm{st}$ & 2nd & 3rd & 4 th & \\
\hline & \multicolumn{7}{|c|}{ (uillion kilowatthours) } \\
\hline $91 / 30$ & 269.1 & 225.1 & 267.5 & 216.5 & 278.5 & 233.1 & 11.3 \\
\hline $91 / 40$ & $\cdot$. & 225.3 & 267.8 & 210.2 & 278.4 & 233.5 & $13 .:$ \\
\hline $92 / 10$ & .. & -. & 266.1 & 213.9 & 270.2 & 229.2 & 11.5 \\
\hline $92 / 20$ & $\ldots$ &.- & -. & 213.7 & 270.0 & 229.0 & 6.7 \\
\hline $92 / 30$ &.. & -. & -. & -. & 269.6 & 228.4 & 7.6 \\
\hline $92 / 40$ &.. & -. & -. & .. & .. & 230.9 & 3.9 \\
\hline Actual & 274.9 & 222.1 & 246.8 & 203.8 & 255.9 & 227.0 & \\
\hline \multirow[t]{2}{*}{ Average Absolute Error } & 2.8 & 3.1 & 20.3 & 11.3 & 17.5 & 3.7 & 10.7 \\
\hline & \multicolumn{7}{|c|}{ (percent error) } \\
\hline $91 / 30$ & -1.0 & 1.3 & 8.4 & 6.2 & 8.8 & 2.7 & 4.8 \\
\hline $91 / 4 \mathrm{Q}$ & .. & 1.4 & 8.5 & 6.1 & 8.8 & 2.9 & 5.7 \\
\hline $92 / 10$ & -. & -. & 7.8 & 5.0 & 5.6 & 1.0 & 4.9 \\
\hline $92 / 20$ & .. & -. & -. & 4.9 & 5.5 & 0.9 & 3.8 \\
\hline $92 / 30$ & .. & -- & .. & $\cdot \cdot$ & 5.4 & 0.6 & 3.1 \\
\hline $92 / 4 Q$ & -. & $-\cdot$ & $-\cdot$ & -. & -. & 1.7 & 1.7 \\
\hline Average Absolute Percent Error & 1.0 & 1.4 & 8.2 & 5.5 & 6.8 & 1.6 & 4.5 \\
\hline
\end{tabular}

.. = Not applicable.

Sources: Actual data are based on published numbers from the Energy Information A Jministration, Monthly Energy Review, DOE/EIA-0035(93/03); forecasts are taken from the base or mid-case scenarios of the Short-Term Energy Outlook.

Table A30. Commercial Electricity Sales, Actual Versus Forecasts

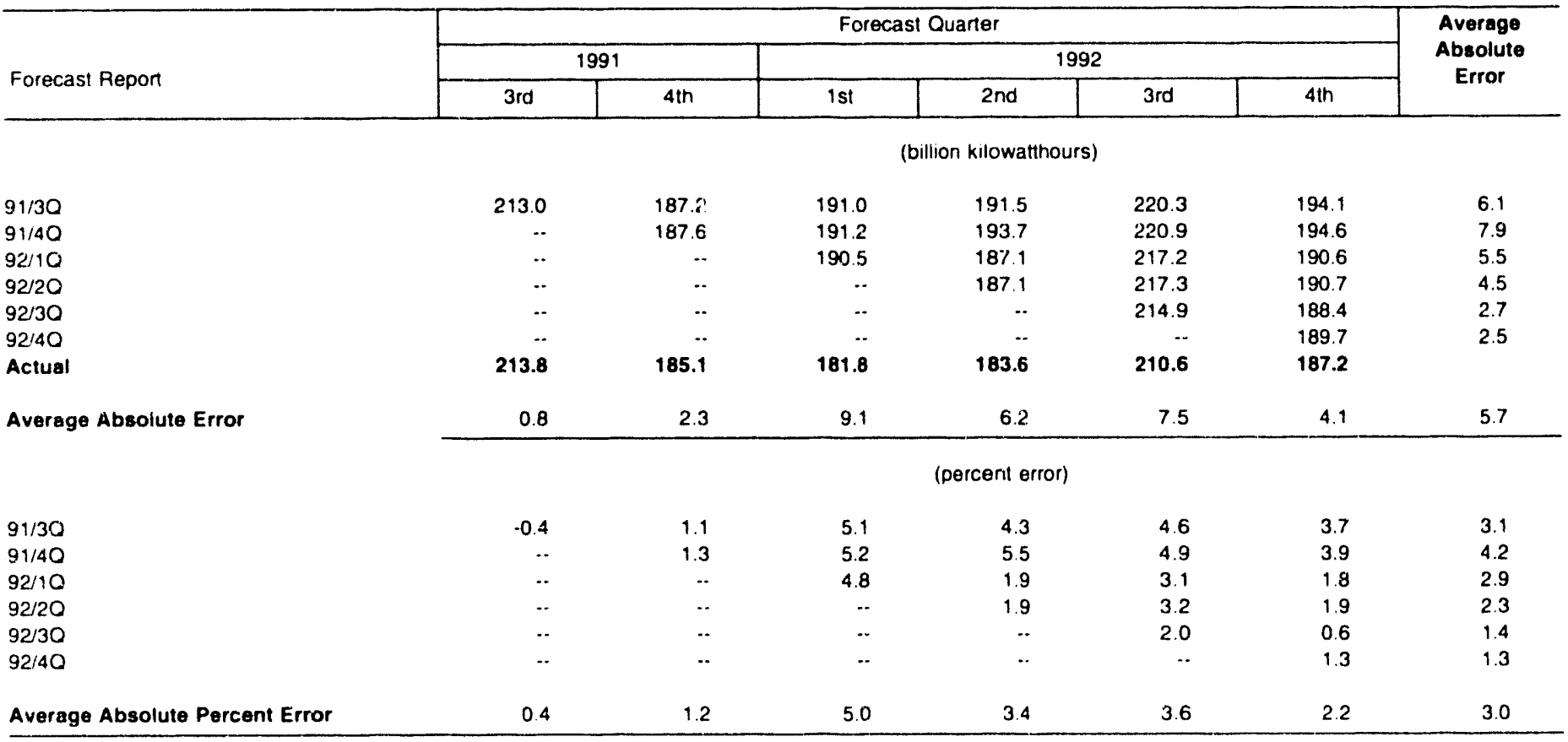

.. = Not applicable.

Sources: Actual data are based on published numbers fromi the Energy Information Administration, Monthly Energy Review, DOE/EIA-0035(93/03); forecasts are iaken from the base or mid-case scenarios of the Short-Term Energy Outlook. 
Table A31. Industrial Electricity Sales, Actual Versus Forecasts

\begin{tabular}{|c|c|c|c|c|c|c|c|}
\hline \multirow{3}{*}{ Forecast Report } & \multicolumn{6}{|c|}{ Forecasi Quarter } & \multirow{3}{*}{$\begin{array}{c}\text { Average } \\
\text { Absolute } \\
\text { Error }\end{array}$} \\
\hline & \multicolumn{2}{|c|}{1991} & \multicolumn{4}{|c|}{1992} & \\
\hline & 3rd & 4 th & $1 \mathrm{st}$ & 2nd & 3rd & 4 th & \\
\hline & \multicolumn{7}{|c|}{ (billion kilowatthours) } \\
\hline $91 / 30$ & 239.4 & 235.5 & 232.8 & 235.9 & 247.4 & 241.0 & 3.5 \\
\hline $91 / 40$ & .. & 236.3 & 233.4 & 243.4 & 247.3 & 241.3 & 2.4 \\
\hline $92 / 10$ & .. & .. & 232.1 & 236.4 & 245.1 & 238.1 & 3.8 \\
\hline $92 / 20$ & .. & .. & .. & 236.0 & 244.5 & 237.0 & 5.5 \\
\hline $92 / 30$ & .. & -. & .. & .. & 248.5 & 240.4 & 2.8 \\
\hline $92 / 40$ & .. & .. & .. & .. & .. & 239.1 & 3.0 \\
\hline Actual & 248.1 & 236.5 & 231.2 & 239.7 & 252.3 & 242.1 & \\
\hline \multirow[t]{2}{*}{ Average Absolute Error } & 8.7 & 0.6 & 1.6 & 3.6 & 5.8 & 2.6 & 3.5 \\
\hline & \multicolumn{7}{|c|}{ (percent error) } \\
\hline $91 / 30$ & -3.5 & -0.4 & 0.7 & -1.6 & -2.0 & -0.4 & 1.5 \\
\hline $91 / 40$ & .. & -0.1 & 1.0 & 1.6 & -2.0 & -0.3 & 1.0 \\
\hline $92 / 10$ & .. & .. & 0.4 & -1.4 & -2.9 & -1.6 & 1.6 \\
\hline $92 / 20$ & .. & -. & -- & -1.5 & -3.1 & -2.1 & 2.3 \\
\hline $92 / 30$ & .. & .. & .- & .. & -1.5 & -0.7 & 1.1 \\
\hline $92 / 40$ & $\cdots$ & $\cdot-$ & $-\cdot$ & .. & -. & -1.2 & 1.2 \\
\hline Average Absolute Percent Error & 3.5 & 0.2 & 0.7 & 1.5 & 2.3 & 1.1 & 1.4 \\
\hline
\end{tabular}

-- = Not applicable.

Sources: Actual data are based on published numbers from the Energy Information Administration, Monthly Energy Review, DOE/EIA-0035(93/03); forecasts are taken from the base or mid-case scenarios of the Short-Term Energy Outlook.

Table A32. Electricity Generation from Coal, Actual Versus Forecasts

\begin{tabular}{|c|c|c|c|c|c|c|c|}
\hline \multirow{3}{*}{ Forecast Repont } & \multicolumn{6}{|c|}{ Forecast Quarter } & \multirow{3}{*}{$\begin{array}{c}\text { Average } \\
\text { Absolute } \\
\text { Error }\end{array}$} \\
\hline & \multicolumn{2}{|c|}{1991} & \multicolumn{4}{|c|}{1992} & \\
\hline & 3rd & $4 \mathrm{th}$ & $1 \mathrm{st}$ & 2nd & 3rd & 4th & \\
\hline & \multicolumn{7}{|c|}{ (billion kilowatthours) } \\
\hline $91 / 30$ & 429.5 & 394.7 & 405.7 & 384.9 & 441.9 & 402.8 & 13.2 \\
\hline $91 / 40$ & .. & 401.3 & 404.5 & 381.7 & 433.2 & 414.5 & 14.5 \\
\hline $92 / 10$ & .. & .. & 399.8 & 366.0 & 421.2 & 397.6 & 7.3 \\
\hline $92 / 20$ &.- & .. & .. & 364.6 & 418.0 & 397.7 & 6.9 \\
\hline $92 / 30$ & .. & .. & .. & .. & 421.1 & 394.9 & 3.0 \\
\hline $92 / 4 Q$ & .. & .. & .. & .. & .. & 398.7 & 7.2 \\
\hline Actual & 417.3 & 387.4 & 386.6 & 373.4 & 423.8 & 381.5 & \\
\hline \multirow[t]{2}{*}{ Average Abeolute Error } & 2.8 & 2.6 & 16.7 & 9.0 & 7.7 & 9.5 & 10.3 \\
\hline & \multicolumn{7}{|c|}{ (percent error) } \\
\hline $91 / 30$ & 2.9 & 1.9 & 4.9 & 3.1 & 4.3 & 2.9 & 3.3 \\
\hline $91 / 40$ & .. & 3.6 & 4.6 & 2.2 & 2.2 & 5.9 & 3.7 \\
\hline $92 / 10$ & .. & .. & 3.4 & -2.0 & .0 .6 & 1.6 & 1.9 \\
\hline $92 / 20$ & -. & -. & -. & -2.4 & -1.4 & 1.6 & 1.7 \\
\hline $92 / 30$ & .. & .. & .. & .. & -0.6 & 0.9 & 0.7 \\
\hline $92 / 4 Q$ & $-\cdot$ & .. & .. & -. & -. & 1.8 & 1.8 \\
\hline Average Abcolute Percent Error & 2.9 & 2.7 & 4.3 & 2.4 & 1.8 & 2.4 & 2.6 \\
\hline
\end{tabular}

-. = Not applicable.

Sources: Actual data are based on published numbers from the Energy Information Administration, Monthly Energy Review, DOE/EIA-0035(93/03); forecasts are taken from the base or mid-case scenarios of the Short-Term Energy Outlook. 
Table A33. Electricity Generation from Petroleum, Actual Versus Forecasts

\begin{tabular}{|c|c|c|c|c|c|c|c|}
\hline \multirow{3}{*}{ Forecast Report } & \multicolumn{6}{|c|}{ Forecast Quarter } & \multirow{3}{*}{$\begin{array}{c}\text { Average } \\
\text { Absolute } \\
\text { Error }\end{array}$} \\
\hline & \multicolumn{2}{|c|}{1991} & \multicolumn{4}{|c|}{1992} & \\
\hline & $3 r d$ & 4th & $1 \mathrm{st}$ & 2nd & 3rd & 4th & \\
\hline & \multicolumn{7}{|c|}{ (billion kilowatthours) } \\
\hline $91 / 30$ & 27.8 & 28.4 & 32.3 & 23.1 & 29.1 & 29.0 & 5.7 \\
\hline $91 / 40$ & -. & 30.2 & 22.5 & 29.5 & 32.2 & 23.1 & 7.1 \\
\hline $92 / 10$ & -. & -. & 29.2 & 29.5 & 30.2 & 21.8 & 5.6 \\
\hline $92 / 2 Q$ & .. & -. & -. & 28.9 & 29.3 & 21.3 & 6.1 \\
\hline $92 / 30$ & -. & -. & .. & .. & 27.1 & 24.0 & 4.3 \\
\hline $92 / 4 Q$ & .. & -. & -. & $-\cdot$ & -. & 24.1 & 3.9 \\
\hline Actual & 31.5 & 23.0 & 27.3 & 18.7 & 22.3 & 20.2 & \\
\hline \multirow[t]{2}{*}{ Average Absolute Error } & 3.7 & 6.3 & 3.9 & 9.0 & 7.3 & 3.7 & 5.9 \\
\hline & \multicolumn{7}{|c|}{ (percent error) } \\
\hline $91 / 3 Q$ & -11.7 & 23.7 & 18.3 & 23.5 & 30.4 & 43.9 & 23.9 \\
\hline $91 / 40$ & -. & 31.5 & -17.6 & 57.7 & 44.3 & 14.6 & 32.0 \\
\hline $92 / 10$ & $\cdot$ & $\cdot$ & 6.9 & 57.7 & 35.3 & 8.2 & 25.1 \\
\hline $92 / 2 Q$ & $*$ & -. & -. & 54.5 & 31.3 & 5.7 & 30.0 \\
\hline $92 / 30$ & .. & -. & -- & -- & 21.5 & 19.1 & 20.3 \\
\hline $92 / 40$ & $\cdot \cdot$ & $\cdot \cdot$ & $-\cdot$ & $\cdots$ & 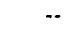 & 19.6 & 19.6 \\
\hline Average Absolute Percent Error & 11.7 & 27.6 & 14.3 & 48.3 & 32.6 & 17.9 & 27.5 \\
\hline
\end{tabular}

.. = Not applicable.

Sources: Actual data are based on published numbers from the Energy Information Administration, Monthly Energy Review, DOE/ElA-0035(93/03); forecasts are taken from the base or mid-case scenarios of the Short-Term Energy Outlook.

Table A34. Electricity Generation from Natural Gas, Actual Versus Forecasts

\begin{tabular}{|c|c|c|c|c|c|c|c|}
\hline \multirow{3}{*}{ Forecast Report } & \multicolumn{6}{|c|}{ Forecast Quarter } & \multirow{3}{*}{$\begin{array}{c}\text { Average } \\
\text { Absolute } \\
\text { Error }\end{array}$} \\
\hline & \multicolumn{2}{|c|}{1991} & \multicolumn{4}{|c|}{1992} & \\
\hline & 3rd & 4th & $1 \mathrm{st}$ & 2nd & 3 rd & $4 \mathrm{th}$ & \\
\hline & \multicolumn{7}{|c|}{ (billion kilowatthours) } \\
\hline $91 / 3 Q$ & 82.5 & 59.5 & 50.9 & 65.5 & 84.6 & 60.1 & 3.0 \\
\hline $91 / 40$ & $\cdot \cdot$ & 59.8 & 51.6 & 71.0 & 91.8 & 60.7 & 2.6 \\
\hline $92 / 10$ & -. & -. & 51.6 & 67.1 & 84.8 & 59.6 & 2.4 \\
\hline $92 / 20$ & -. & -. & $-\cdot$ & 69.1 & 87.9 & 58.0 & 1.5 \\
\hline $92 / 30$ & -. & .. & -. & -. & 91.7 & 61.8 & 5.8 \\
\hline $92 / 40$ & .. & $\cdot \cdot$ &.. & -. & .. & 64.5 & 9.4 \\
\hline Actual & 87.1 & 60.2 & 52.2 & 69.5 & 86.8 & 55.1 & \\
\hline \multirow[t]{2}{*}{ Average Absolute Error } & 4.6 & 0.5 & 0.9 & 2.1 & 3.0 & 5.6 & 3.1 \\
\hline & \multicolumn{7}{|c|}{ (percent error) } \\
\hline $91 / 3 Q$ & .5 .3 & -1.2 & $\cdot 2.6$ & -5.8 & -2.5 & 9.0 & 4.3 \\
\hline $91 / 4 Q$ & $\cdots$ & -0.7 & .1 .2 & 2.1 & 5.8 & 10.1 & 4.0 \\
\hline $92 / 10$ & .. & .. & -1.2 & -3.5 & -2.3 & 8.1 & 3.6 \\
\hline $92 / 20$ & .. & -. & -. & -0.6 & 1.3 & 5.2 & 2.1 \\
\hline $92 / 30$ & .. & .. & -- & -- & 5.7 & 12.1 & 8.2 \\
\hline $92 / 40$ & -. & -. & $\cdot-$ & -. & $\cdots$ & 17.0 & 17.0 \\
\hline Average Absolute Percent Error & 5.3 & 0.9 & 1.7 & 3.0 & 3.5 & 10.2 & 4.9 \\
\hline
\end{tabular}

.. = Not applicable.

Sources: Actual data are based on published numbers from the Energy Information Administration, Monthly Energy Review, DOE/EIA-0035(93/03); forecasts are taken from the base or mid-case scenarios of the Short-Term Energy Outlouk. 
Table A35. Electricity Generation from Nuclear Power, Actual Versus Forecasts

\begin{tabular}{|c|c|c|c|c|c|c|c|}
\hline \multirow{3}{*}{ Forecast Report } & \multicolumn{6}{|c|}{ Forecast Quarter } & \multirow{3}{*}{$\begin{array}{c}\text { Average } \\
\text { Absolute } \\
\text { Error }\end{array}$} \\
\hline & \multicolumn{2}{|c|}{1991} & \multicolumn{4}{|c|}{1992} & \\
\hline & 3rd & 4 th & $1 \mathrm{st}$ & $2 n d$ & 3rd & 4 th & \\
\hline & \multicolumn{7}{|c|}{ (billion kilowatthours) } \\
\hline $91 / 30$ & 154.5 & 138.2 & 147.9 & 135.1 & 156.0 & 141.9 & 10.6 \\
\hline $91 / 4 Q$ & .. & 139.7 & 153.7 & 133.8 & 158.3 & 140.5 & 8.1 \\
\hline $92 / 10$ & -. & -. & 159.1 & 138.5 & 163.9 & 145.4 & 4.3 \\
\hline $92 / 2 \mathrm{Q}$ & -. &.- & -. & 140.3 & 166.0 & 147.3 & 4.0 \\
\hline $92 / 30$ & -. & $-\cdot$ & .. & - & 165.8 & 147.1 & 5.3 \\
\hline $92 / 40$ & -. & - & .. & -. & -. & 151.3 & 6.3 \\
\hline Actual & 171.1 & 147.5 & 156.5 & 139.1 & 165.6 & 157.6 & \\
\hline \multirow[t]{2}{*}{ Average Absolute Error } & 16.6 & 8.6 & 4.7 & 2.8 & 3.8 & 12.0 & 7.1 \\
\hline & \multicolumn{7}{|c|}{ (percent error) } \\
\hline $91 / 30$ & -9.7 & -6.3 & -5.5 & -2.9 & -5.8 & .10 .0 & 6.8 \\
\hline $91 / 4 Q$ & -. & $\cdot 5.5$ & -1.8 & -3.8 & -4.4 & -10.8 & 5.3 \\
\hline $92 / 10$ & .. & -- & 1.7 & -0.4 & -1.0 & -7.7 & 2.8 \\
\hline $92 / 20$ & -. & .. & -- & 0.9 & 0.2 & -6.5 & 2.6 \\
\hline $92 / 30$ & -. & .. & .. & -. & 0.1 & -6.7 & 3.3 \\
\hline $92 / 4 Q$ & -. & $\cdot \cdot$ & 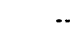 & $\cdots$ & $-\cdot$ & -4.0 & 4.0 \\
\hline Average Absolute Percent Error & 9.7 & 5.8 & 3.0 & 2.0 & 2.3 & 7.6 & 4.5 \\
\hline
\end{tabular}

.- = Not applicable.

Sources: Actual data are based on published numbers from the Energy Information Administration, Monthly Energy Review, DOE/EIA-0035(93/03); forecasts are taken from the base or mid-case scenarios of the Short-Term Energy Outlook.

Table A36. Electricity Generation from Hydroelectric Power, Actual Versus Forecasts

\begin{tabular}{|c|c|c|c|c|c|c|c|}
\hline \multirow{3}{*}{ Forecast Report } & \multicolumn{6}{|c|}{ Forecast Quarter } & \multirow{3}{*}{$\begin{array}{c}\text { Average } \\
\text { Absolute } \\
\text { Error }\end{array}$} \\
\hline & \multicolumn{2}{|c|}{1991} & \multicolumn{4}{|c|}{1992} & \\
\hline & 3rd & 4 th & $1 \mathrm{st}$ & 2nd & 3rd & $4 \operatorname{th}$ & \\
\hline & \multicolumn{7}{|c|}{ (billion kilowatthours) } \\
\hline $91 / 30$ & 68.1 & 68.7 & 79.6 & 82.4 & 68.2 & 69.1 & 12.4 \\
\hline $91 / 4 Q$ & -. & 67.1 & 78.1 & 82.4 & 68.2 & 69.1 & 13.5 \\
\hline $92 / 10$ & .. & -. & 75.5 & 80.2 & 66.2 & 69.1 & 12.9 \\
\hline $92 / 2 Q$ &.$\cdot$ &.$\cdot$ & -. & 77.2 & 64.9 & 69.2 & 11.0 \\
\hline $92 / 30$ & -. & -. & $\cdot \cdot$ & -. & 63.0 & 67.2 & 8.1 \\
\hline $92 / 40$ &.. &.. & .. & .. & .. & 63.2 & 3.7 \\
\hline Actual & 64.4 & 57.7 & 61.0 & 64.4 & 54.6 & 59.5 & \\
\hline \multirow[t]{2}{*}{ Average Absolute Error } & 3.7 & 10.2 & 16.7 & 16.2 & 11.5 & 8.4 & 11.7 \\
\hline & \multicolumn{7}{|c|}{ (percent error) } \\
\hline $91 / 30$ & 5.7 & 19.0 & 30.4 & 28.0 & 25.0 & 16.2 & 8.5 \\
\hline $91 / 4 Q$ & -. & 16.3 & 27.9 & 28.0 & 25.0 & 16.2 & 7.3 \\
\hline $92 / 10$ &.. & .. & 23.7 & 24.5 & 21.3 & 16.2 & 5.6 \\
\hline $92 / 20$ & .. & -. & -- & 19.9 & 18.9 & 16.4 & 7.4 \\
\hline $92 / 3 Q$ & -. & -. & .. & -. & 15.5 & 13.0 & 12.0 \\
\hline $92 / 4 Q$ & $\cdot \cdot$ & -- & -- & $\cdots$ & .. & 6.3 & 16.3 \\
\hline Average Absolute Percent Error & 5.7 & 17.7 & 27.3 & 25.1 & 21.1 & 14.0 & 19.7 \\
\hline
\end{tabular}

-. = Not applicable.

Sources: Actual data are based on published numbers from the Energy Information Administration, Monthly Energy Review, DOE/EIA-0035(93/03); forecasts are taken from the base or mid-case scenarios of the Short-Term Energy Outlook. 


\section{Appendix B \\ Placing Uncertainty Estimates on Key Exogenous Inputs to STIFS}

\section{Overview}

In order to incorporate uncertainty about the exogenous inputs to the STIFS model when computing forecast standard errors, probability distributions must be assigned to the exogenous variables so that the uncertainty can be quantified. The most straightforward way to accomplish this was to construct a new module for STIFS that contained relatively simple equations to describe the behavior of the exogenous variables over time. Estimation of the parameters, parameter covariances, and error covariances for this module, combined with the same information from the STIFS model itself, provided the statistics needed to perform stochastic simulation of the entire STIFS model over an appropriate period. A listing and description of the exogenous variables included in the new module and the general specifications used are provided in Table B1.

For the most part, the exogenous variables were characterized as emanating from a random walk process (with or without drift, as appropriate), unless something specific was known or was to be assumed about a more elaborate specification for a particular variable. Of the 50 exogenous variables made stochastic for the stochastic simulation exercise, 37 were determined through simple estimating equations, 8 were determined through identities involving combinations of the directly estimated variables, and the remaining 5 (weather variables) were determined through established rules-of-thumb. Of the 37 variables with estimating equations, one was a simple random walk, 20 were random walks with drift, 2 were random walks with seasonal variation, 6 were random walks with drift where the drift term was allowed to make discrete shifts, 2 were simple linear combinations of other variables (composites with estimated weights), and the rest were special formulations based on certain external assumptions. In addition to the simple stochastic formulations of the variables, checks for (at least first-order) autocorrelation of the errors were made, and the models augmented as appropriate.

For the special variables, some additional motivation is warranted. The most important variable in this class is the average delivered price of imported oil to U.S. refiners, dubbed "RAIMUUS" in the STIFS naming system. ${ }^{58}$ The following is the estimating equation used to capture expected variability of RAIMUUS:

$$
\begin{aligned}
\text { RAIMUUS }_{t}= & \text { RAIM_0 + RAIM_T }{ }^{*} t \\
& + \text { RAIM_D*D90I91 } B_{t}
\end{aligned}
$$

where:

$\mathrm{t}=$ integer-valued trend variable (and time index $)=1,2,3, \ldots$ etc.

D90191B = Dummy variable equal to 1 for September 1990 through February 1991, 0 otherwise

RAIM_0, RAIM_T, RAIM_D are estimated parameters

\footnotetext{
${ }^{5}$ For a complete reference for the STIFS model specification and data nomenclature and definitions, see Energy Information

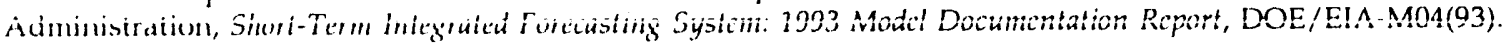


Table B1. Key Exogenous Variables from STIFS ${ }^{a}$ Used in Stochastic Simulation

\begin{tabular}{|c|c|c|}
\hline Variable & Definition & Specification \\
\hline CICPIUS & Consumer price index, all urban, seasonally adjusted & RWD \\
\hline WPCPIUS & Wholesale price index, seasonally adjusted & RWD \\
\hline WPIINUS & Wholesale price index, non-energy/non-food, seasonally adjusted & RWD \\
\hline FEERIUS & Real composite dollar exchange rate & SAWD \\
\hline PRIMEUS & U.S. prime rate & SFWD \\
\hline YD870US & Real disposable personal income, $\$ 1987$ & RWD \\
\hline I87RXUS & Real aggregate fixed investment, $\$ 1987$ & Other \\
\hline GDPDIUS & Gross domestic product deflator, $1987=1.0$ & RWD \\
\hline GDPQXUS & Real gross domestic product, $\$ 1987$ & RWD \\
\hline GNPDIUS & Gross national product deflator, $1987=1.0$ & RWD \\
\hline GNPQXUS & Real gross national product, $\$ 1987$ & RWD \\
\hline EMCMPUS & Commercial employment, millions & RWD \\
\hline EMNFPUS & Non-farm employment, millions & RWD \\
\hline EMPIPUS & Manufacturing employment, millions & RWD \\
\hline EMPMPUS & Mining employment, millions & RWD \\
\hline ELNIPUS & Net imports of electricity & SRWD \\
\hline ELNSPUS & Purchases from nonutilities of electricity by electric utilities & RWD \\
\hline HYEOPUS & Hydroelectric net generation of electricity & RWS \\
\hline NUEOPUS & Nuclear-powered net generation of electricity & RWS \\
\hline KQHMPUS & Housing stock, millions & RWD \\
\hline KQH1PUS & Housing stock, excluding mobile homes & Other \\
\hline KRDRXUS & Manufacturing business inventory change, $\$ 1987$ & RW \\
\hline ORCAPUS & Operable refinery capacity, million barrels per day & SRWD \\
\hline PAPRPAK & Alaskan crude oil production, million barrels per day & SRWD \\
\hline PAPRP 48 & Lower 48 crude oil production, million barrels per day & RWD \\
\hline RAIMUUS & Average delivered price of imported crude oil to U.S. refiners & DT \\
\hline RACPUUS & Average composite (imported and domestic) delivered price of crude oil to U.S. refiners & Other \\
\hline ZGHDPUS & Gas customer-weighted heating degree-days, total U.S. & ROT \\
\hline ZWCDPUS & Population-weighted cooling degree-days, total U.S. & ROT \\
\hline ZWHDPUS & Population-weighted heating degree-days, total U.S. & ROT \\
\hline ZWHDPMA & Population-weighted heating degree-days, Mid Atlantic states & ROT \\
\hline ZWHDPNE & Population-weighted heating degree-days, New England states & ROT \\
\hline ZOCBIUS & Industrial production index, basic chemicals & SRWD \\
\hline ZOISIUS & Industrial production index, iron and steel & RWD \\
\hline ZOMNIUS & Industrial production index, total manufacturing & Other \\
\hline ZOTOIUS & Industrial production index, total industry & Other \\
\hline ZO2OIUS & Industrial production index, food & RWD \\
\hline ZO26IUS & Industrial production index, paper & RWD \\
\hline ZO28IUS & Industrial production index, chemicals & RWD \\
\hline zO29IUS & Industrial production index, petroleum refining & Other \\
\hline ZO32IUS & Industrial production index, stone, clay, glass & Other \\
\hline ZO33IUS & Indusirial production index, primary metals & RWD \\
\hline QSIC & Gas-weighted industrial production index & ID \\
\hline zosilus & Coal-weighted industrial production index & ID \\
\hline PRIME6 & Moving average (six month) for prime rate (PRIMEUS) & ID \\
\hline PRIMELG & Twelve-month lag on PRIME6 & ID \\
\hline PAPRPUS & Total U.S. crude oil production & ID \\
\hline ZWHDPNO & Heating degree-days, Northeast States & ID \\
\hline ZWHDDNO & Deviations from normal heating degree-days, Northeast States & ID \\
\hline ZWHDDUS & Deviations from normal heating degree-days, total U.S. & ID \\
\hline
\end{tabular}

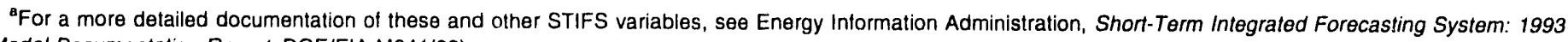
Model Documentation Report, DOE/EIA-M041(93).

DT $=$ Deterministic trend.

$I D=$ Identity.

ROT = Rule of thumb.

AW $=$ Simple random walk.

RWD = Random walk with drift.

AWS = Random walk with seasonal variation

SAWD $=$ Random walk with shifting drift.

Other = Other specification. 
This particular specitication was designed to limit the characterization of RAIMUUS to a deterministic trend because it was judged that the recent relative stability of world crude oil prices will most likely continue for the next few yours, with prices possibly drifting upward slightly as world excess oil production capacity diminishes. The specification in Equation BI prevents random shocks in stochastic simulation from being permanent. The estimation of Equation 1 was limited to September 1980 onward, since it was deemed that this point marked the heginning of a new era for oil price behavior following the oil price collapse of 1986. Figure $\mathrm{Bl}$ illustrates the path of oil prices since 1981. Aside from the spike appearing during the Gulf war in $1990 / 1091$, prices have been relatively stable but trending slightly upward since about the middle of 1986. The Culf war provided ample evidence of the types of shocks that world oil markets may be subject to, but for this analysis the contribution of such extreme events to the uncertainty of oil prices as characterized in STIFS was minimized by creating a dummy variable for the Ciulf war period ("I)4(9)[13"). A test was done to determine the difference in the error variance between specification $\Lambda 1$ and two alternatives, namely a specification in which the ciulf war is not treated with a dummy variable (but the estimation period is the same) and one in which the RAIMUUS is modeled as a random walk for the entire period shown in Figure B1. The standard error of the regression for all three RAIMUUS specifications is given below:

\section{RAIMUUS \\ Alternatives \\ Standard Error of Regression}

Another variable that is handled somewhat differently in this analysis is ZO32IUS, the industrial production index for the manufacturing industry with Standard Industrial Classification (SIC) 32, "Stone, Clay and Glass." Since the fortunes of this industry are significantly affected by developments in the housing and construction industry market, it was assumed that a specification for ZO32IUS that tied in with the specification to be applied to the key housing variable used in STIFS (KQHMPUS - housing stock) would be an internally consistent approach. The specification used is based on the assumption that changes in ZO32IUS will be directly related to deviations of housing stock growth from its long-term trend. This idea is summarized as follows:

$$
\begin{aligned}
\text { ZO32IUS }_{t}= & \text { ZO32IUS }_{t-1} \\
& + \text { ZO32_KQ*(KQHMPUS }_{t} \\
& - \text { KQHMPUS }_{t-1} \\
& - \text { KQHM_BO }+ \text { ez32, }
\end{aligned}
$$

where:

$$
\begin{array}{ll}
\text { KQHMPUS }_{t} & =\text { Housing stock, millions, time } t \\
\mathrm{ez}^{3} 2_{\mathrm{t}} & =\text { error term, time } t, \text { for ZO32IUS }
\end{array}
$$

ZO32_KQ,KQHM_B0 are estimated parameters

and where:

$$
\begin{aligned}
\mathrm{KQHMPUS}_{t}= & \mathrm{KQHM} \_\mathrm{BO}+\mathrm{KQHMPUS}_{t-1} \\
& +\mathrm{ekq}_{\mathrm{t}}
\end{aligned}
$$

is the stochastic formulation used for the housing stock, with

$$
\mathrm{ekq}_{\mathrm{t}}=\text { error term, time } \mathrm{t} \text {, for } \mathrm{KQHMPUS}
$$

One additional equation worth mentioning separately is the equation for the industrial production index refining (ZO29IUS), a variable which has a nearly identical (aside from a constant indexing factor) counterpart in STIFS, namely "PAROPUS" or total refinery output (million barrels per day). It is assumed that changes in ZO29IUS and PAROPUS are proportional to each other. Figure B2 illustrates the correctness of that assumption. The treatment of the variable ZO29IUS is summarized below: 
Figure B1. Imported Crude Oil Price

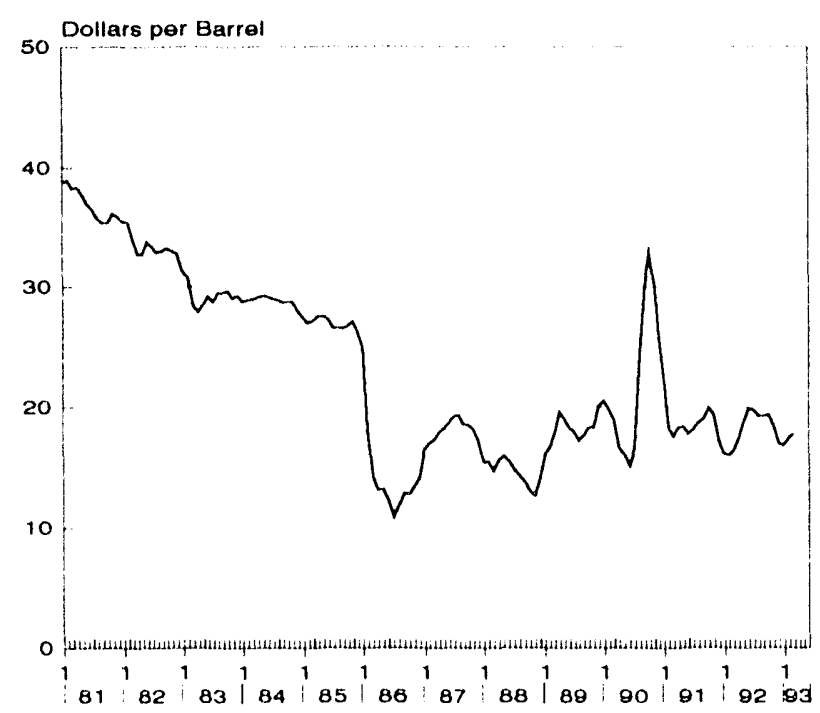

Figure B2. Refinery Output Measures

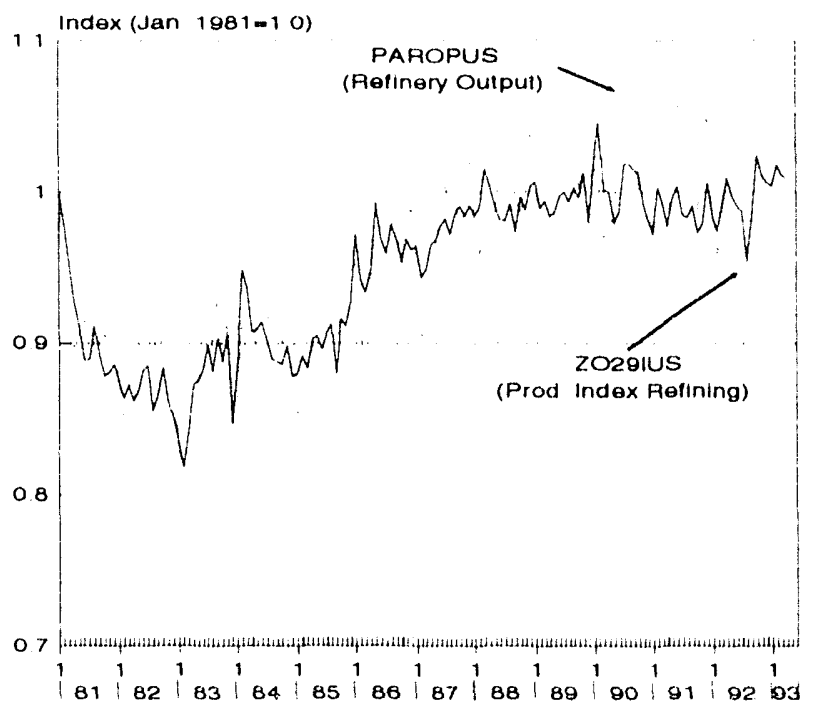

(B4)

$$
\begin{aligned}
& \text { ZO291US }_{1}=\text { ZO29IUS }_{1} \\
& \text { + ZO29_PA*(PAROPUS } \\
& \text { - PAROPUS }{ }_{1-1} \text { ) + ez29, }
\end{aligned}
$$

where:

ez29, $=$ error term, time $t$, for ZO29IUS

ZO29,Z.O29_PA are estimated parameters

It may not actually be necessary or desirable to include an autonomous shock for Z.O29IUS, and preferable to simply allow the error term on PAROPUS to be the entire source of uncertainty for ZO29IUS by making the variables strictly proportional. For now, Equation $B 4$ is used.

Another class of special variables were the weather variables, which, except for possible autoregressive disturbances, were assumed to be equal to long-term (30)-year) average (or normal) values.

\section{Model Specification}

A convenient summary of the approach used in preparing the extension of the STIFS model to make exogenous inputs random variables for stochastic simulation is achieved by listing the part of the computer code (written in SAS ${ }^{59}$ ) that provides the complete specification of the module (except for explicit listing of error terms). Estimation of the module was performed using the SAS "MODEL" procedure. For documentation on this and other SAS procedures see SAS/ETS User's Guide, Version 6, SAS Institute, Inc., 1988. Below is listed the formulae from the extension module as it appears in the SAS estimation procedure. 


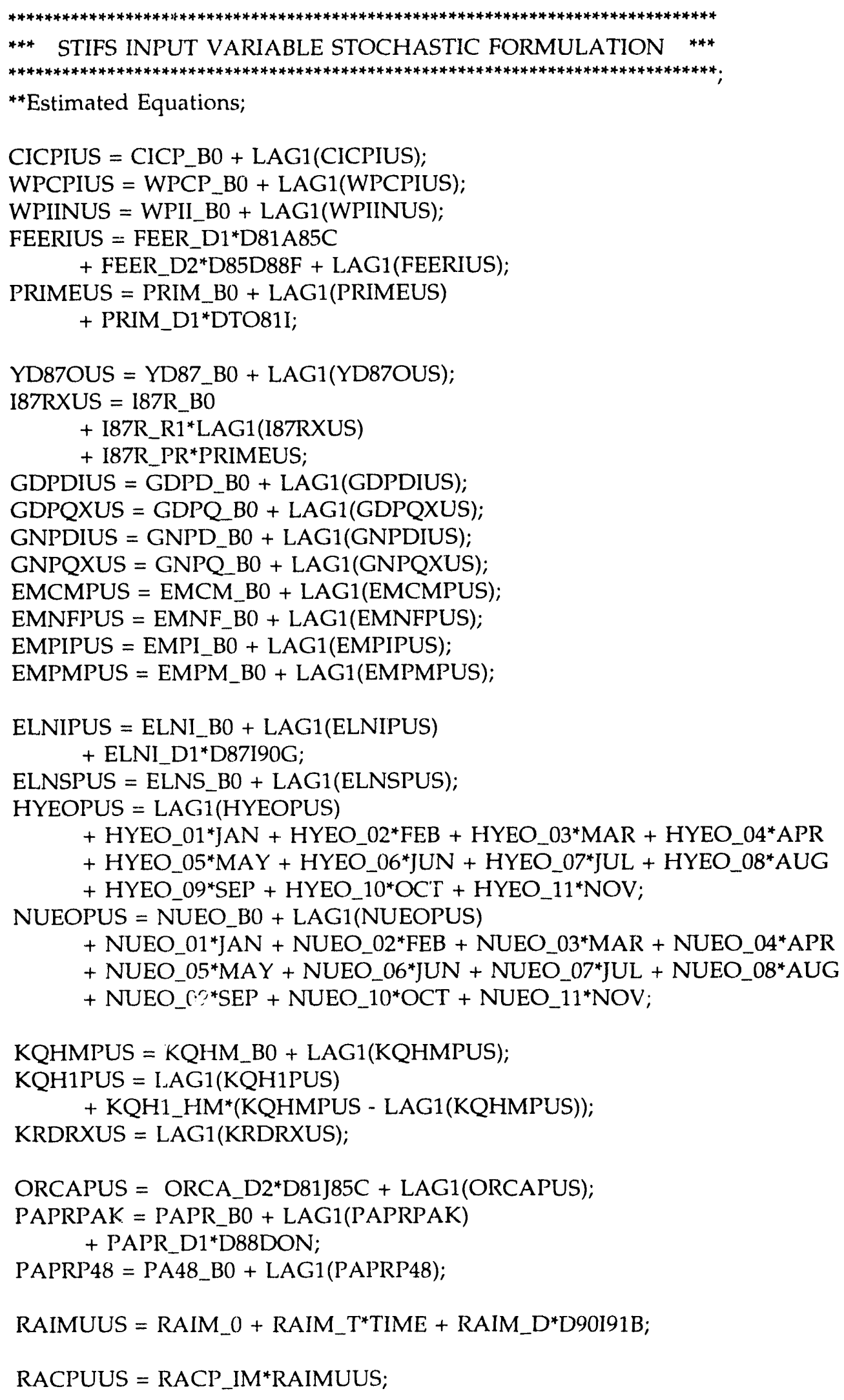


**Weather variables assumed "normal";

ZGHDI'US = ZGHNI'US;

ZWCDPUS = ZWCNPUS;

ZWHDPUS = ZWHNPUS;

ZWHDPMA $=$ ZWHNPMA;

ZWHDPNE = ZWHNINE;

${ }^{* *}$ Other estimated equations;

ZOCBIUS $=$ ZOCB D $1 *$ DS8DON + LAG1(ZOCBIUS);

ZOISIUS $=$ ZOIS_BO + L.ACII(ZOISIUS);

ZOMNIUS = LAG1(ZOMNIUS) + ZOMN_.20*(ZO20IUS - LAG1(ZO20IUS))

+ ZOMN_28*(ZO28IUS - LAG1(ZO2OIUS));

ZOTOIUS = LAG1(ZOTOIUS) + ZOTO_20*(ZO20IUS - LAG1(ZO2OIUS))

+ ZOTO_28*(ZO2RIUS - LAG1(ZO2OIUS));

ZO2OIUS $=$ ZO2() $B()+$ LAG1(ZO2OIUS $)$

ZO26IUS $=$ ZO26 B BO + LACi(ZO26IUS);

ZO28IUS $=$ ZO28 BO + LACi1(ZO28IUS);

ZO29IUS $=$ LAG.1(ZO29IUS)

+ ZO29_PA*(PAROI'US - LAG1(PAROPUS));

ZO32IUS = LAG1(ZO. 32IUS)

+ ZO32_KQ*(KQHIMPUS - LAG1(KQHMPUS) - KQHM_BO);

ZO33IUS = ZO33 BO + LAG1(ZO33IUS);

**Autoregressive error components included;

\%AR(PAPAK,1,PAPRPAK,M=ML)

$\% A R(Z G H D P ' 1, Z G H D P \cup S, M=M L)$

$\% A R(P A P 48,1, P A P R P 48, M=M L$.)

$\%$ AR(HDPUS, $1, Z$ ZWHPUS,M=ML)

$\%$ AR(HDPMA, 1,ZWHDIMA,M=ML)

$\%$ AR(HDINE, 1,ZWHDINE,M=ML)

$\%$ AR(HYEOP,3,HYEOPUS, $123, \mathrm{M}=\mathrm{ML})$

**Some miscellaneous identities;

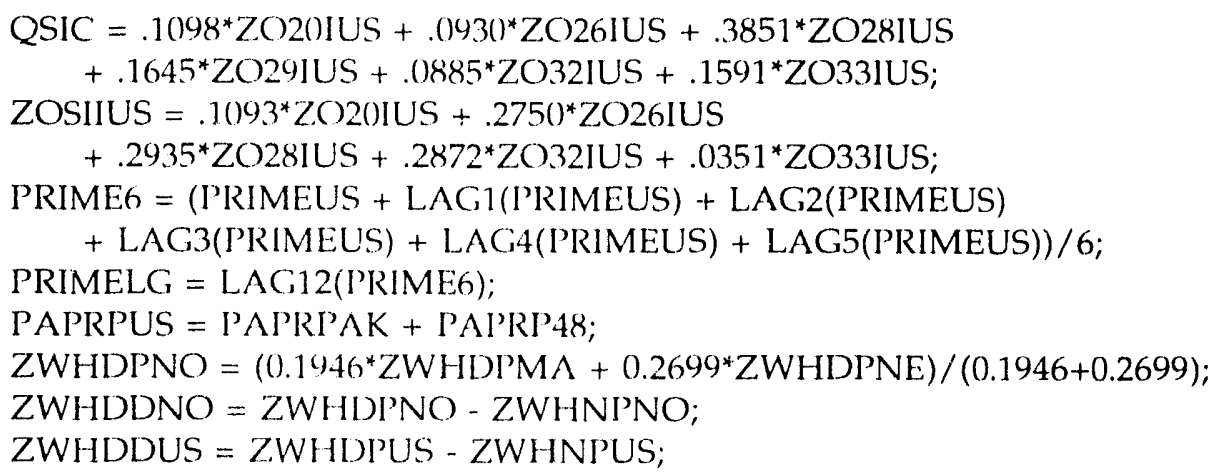

** End of module formulae; 
The parameters of the module are defined as follows:

\begin{tabular}{|c|c|}
\hline CICP_BO & Drift term for CICPIUS \\
\hline WPCP_BO & Drift term for CICPIUS \\
\hline WPII_B0 & Drift term for CICPIUS \\
\hline PRIM_BO & Drift term for CICPIUS \\
\hline PRIM_D1 & Dummy for pre-1981 drift \\
\hline YD87_B0 & Drift term for CICPIUS \\
\hline I87R_BO & Constant term for I87RXUS \\
\hline I87R_R1 & Lag parameter on $187 \mathrm{RXUS}$ \\
\hline I87R_PR & Interest rate parameter for $187 R \times U S$ \\
\hline FEER_D1 & Dummy for Jan. 1981-Mar. 1985 drift in FEERIUS \\
\hline FEER_D2 & Dummy for Apr. 1985-Jun. 1988 drift in FEERIUS \\
\hline GDPD_B0 & Drift term for GDPDIUS \\
\hline GNPD_BO & Drift term for GNPDIUS \\
\hline GDPQBO & Drift term for GDPQXUS \\
\hline GNPQB0 & Drift term for GNPQXUS \\
\hline EMCM_BO & Drift term for EMCMPUS \\
\hline EMNF_BO & Drift term for EMNFPUS \\
\hline EMPI_B0 & Drift term for EMPIPUS \\
\hline EMPM_B0 & Drift term for EMPMPUS \\
\hline ELNI_BO & Drift term for ELNIPUS \\
\hline ELNI_D1 & Dummy for Sep. 1987-Jul. 1990 drift in ELNIPUS \\
\hline ELNS_BO & Drift term for ELNSPUS \\
\hline HYEO_BO & Drift term for HYEOPUS \\
\hline HYEO_01 & Monthly seasonal dummy for HYEOPUS (January) \\
\hline HYEO_02 & Monthly seasonal dummy for HYEOPUS (February \\
\hline HYEO_03 & Monthly seasonal dummy for HYEOPUS (March) \\
\hline HYEO_04 & Monthly seasonal dummy for HYEOPUS (April) \\
\hline HYEO_05 & Monthly seasonal dummy for HYEOPUS (May) \\
\hline HYEO_06 & Monthly seasonal dummy for HYEOPUS (June) \\
\hline HYEO_07 & Monthly seasonal dummy for HYEOPUS (July) \\
\hline HYEO_08 & Monthly seasonal dummy for HYEOPUS (August) \\
\hline HYEO_09 & Monthly seasonal dummy for HYEOPUS (September) \\
\hline HYEO_10 & Monthly seasonal dummy for HYEOPUS (October) \\
\hline HYEO_11 & Monthly seasonal dummy for HYEOPUS (November) \\
\hline NUEO_B0 & Drift term for NUEOPUS \\
\hline NUEO_01 & Monthly seasonal dummy for NUEOPUS (January) \\
\hline NUEO_02 & Monthly seasonal dummy for NUEOPUS (February) \\
\hline NUEO_03 & Monthly seasonal dummy for NUEOPUS (March) \\
\hline NUEO_04 & Monthly seasonal dummy for NUEOPUS (April) \\
\hline NUEO_05 & Monthly seasonal dummy for NUEOPUS (May) \\
\hline NUEO_06 & Monthly seasonal dummy for NUEOPUS (June) \\
\hline NUEO_07 & Monthly seasonal dummy for NUEOPUS (July) \\
\hline NUEO_08 & Monthly seasonal dummy for NUEOPUS (August) \\
\hline NUEO_09 & Monthly seasonal dummy for NUEOPUS (September) \\
\hline NUEO_10 & Monthly seasonal dummy for NUEOPUS (October) \\
\hline NUEO_11 & Monthly seasonal dummy for NUEOPUS (November) \\
\hline KQHM_BO & Drift term for $\mathrm{KQHMPUS}$ \\
\hline ORCA_D2 & Dummy for Sep. 1981-Mar. 1985 drift in ORCAPUS \\
\hline PAPR_B0 & Drift term for PAPRPAK \\
\hline PAPR_D1 & Dummy for post-1987 drift in PAPRPAK \\
\hline PA48_B0 & Drift term for PAPRP48 \\
\hline RAIM_0 & Constant term for RAIMUUS \\
\hline RAIM_R1 & Lag parameter on RAIMUUS \\
\hline
\end{tabular}


RAIM_T

RAIM_D

RACP_BO

RACP_IM

ZOCB_D1

ZOIS_BO

ZOMN_20

ZOMN_28

ZOTO_20

ZOTO_28

$\mathrm{ZO} 20 \_\mathrm{BO}$

$\mathrm{ZO} 26 \_\mathrm{BO}$

$\mathrm{ZO} 28 \_\mathrm{B} 0$

$\mathrm{ZO} 29 \mathrm{PA}$

$\mathrm{ZO} 32 \_\mathrm{KQ}$

ZO33_B0
Deterministic trend term coefficient for RAIMUUS

Intercept dummy for Gulf War for RAIMUUS

Drift term for RACPUUS

Constant of proportionality between RACPUUS and RAIMUUS

Dummy for post-1987 drift in ZOCBIUS

Drift term for ZOISIUS

Coefficient (weight) on ZO20IUS in ZOMNIUS

Coefficient (weight) on ZO28IUS in ZOMNIUS

Coefficient (weight) on ZO20IUS in ZOTOIUS

Coefficient (weight) on ZO28IUS in ZOTOIUS

Drift term for ZO20IUS

Drift term for Z026IUS

Drift term for ZO28IUS

Coefficient on PAROPUS (refinery output) in ZOTOIUS

Coefficient on deviations from trend housing growth in ZO32IUS Drift term for ZO33IUS

The estimation results from the module are presented below. 
Table B2. Estimation Results for STIFS Exogenous Input Variables

\section{Summary Regression Statistics}

\begin{tabular}{|c|c|c|c|c|c|c|c|c|}
\hline Equation & $\begin{array}{r}\text { DF } \\
\text { Model }\end{array}$ & $\begin{array}{l}\text { DF } \\
\text { Error }\end{array}$ & SSE & MSE & Root MSE & R-Square & Adj R-Sq & $\begin{array}{l}\text { Durbin } \\
\text { Watson }\end{array}$ \\
\hline
\end{tabular}

\begin{tabular}{|c|c|c|}
\hline \multicolumn{3}{|c|}{$\begin{array}{l}\text { Regression Group A } \\
\text { RANGE of Fit: } \\
\text { Method of Estimation: }\end{array}$} \\
\hline CICPIUS & 2 & 139 \\
\hline EMCMPUS & 2 & 139 \\
\hline EMNFPUS & 2 & 139 \\
\hline EMPIPUS & 2 & 139 \\
\hline EMPMPUS & 2 & 139 \\
\hline FEERIUS & 3 & 138 \\
\hline GDPDIUS & 2 & 139 \\
\hline GDPQXUS & 2 & 139 \\
\hline GNPDIUS & 2 & 139 \\
\hline GNPQXUS & 2 & 139 \\
\hline HYEOPUS & 14 & 127 \\
\hline 187RXUS & 4 & 137 \\
\hline KQHMPUS & 1.5 & 139.5 \\
\hline KQH1PUS & 1 & 140 \\
\hline KRDRXUS & 1 & 140 \\
\hline NUEOPUS & 12 & 129 \\
\hline ORCAPUS & 1 & 140 \\
\hline PAPRP48 & 2 & 139 \\
\hline PRIMEUS & 3 & 138 \\
\hline WPCPIUS & 2 & 139 \\
\hline WPIINUS & 2 & 139 \\
\hline YD87OUS & 2 & 139 \\
\hline ZOCBIUS & 2 & 139 \\
\hline ZOISIUS & 2 & 139 \\
\hline ZOMNIUS & 3 & 138 \\
\hline zOTOIUS & 3 & 138 \\
\hline zO20IUS & 2 & 139 \\
\hline zO26IUS & 2 & 139 \\
\hline zO28IUS & 2 & 139 \\
\hline ZO29IUS & 2 & 138 \\
\hline zO32IUS & 2.5 & 138.5 \\
\hline ZO33IUS & 1 & 140 \\
\hline ZWCDPUS & 1 & 140 \\
\hline ZWHDPMA & 1 & 140 \\
\hline ZWHDPNE & 1 & 140 \\
\hline ZWHDPUS & 1 & 140 \\
\hline
\end{tabular}

April 1981 to December 1992

Nonlinear Iterated Seemingly Unrelated Regressions with Autoregressive Error Correction

$\begin{array}{rrrrrr}0.0008110 & 5.8348 \mathrm{E}-6 & 0.0024155 & 0.9997 & 0.9997 & 1.503 \\ 0.25832 & 0.0018584 & 0.04311 & 1.0000 & 1.0000 & 1.079 \\ 0.55200 & 0.0039712 & 0.06302 & 0.9999 & 0.9999 & 1.195 \\ 0.01483 & 0.0001067 & 0.01033 & 0.9965 & 0.9964 & 1.112 \\ 0.09217 & 0.0006631 & 0.02575 & 0.9978 & 0.9978 & 1.228 \\ 0.01400 & 0.0001014 & 0.01007 & 0.9940 & 0.9939 & 1.153 \\ 0.0001186 & 8.53001 \mathrm{E}-7 & 0.0009236 & 0.9999 & 0.9999 & 1.377 \\ 8168 & 58.76356 & 7.66574 & 0.9997 & 0.9997 & 0.971 \\ 0.0001182 & 8.50134 \mathrm{E}-7 & 0.0009220 & 0.9999 & 0.9999 & 1.558 \\ 8583 & 61.74928 & 7.85807 & 0.9996 & 0.9996 & 0.998 \\ 0.42809 & 0.0033708 & 0.05806 & 0.8158 & 0.7970 & 1.826 \\ 1377 & 10.05446 & 3.17088 & 0.9977 & 0.9976 & 1.103 \\ 0.03834 & 0.0002748 & 0.01658 & 1.0000 & 1.0000 & 1.291 \\ 0.01131 & 0.0000808 & 0.0089892 & 1.0000 & 1.0000 & 0.028 \\ 19497 & 139.26084 & 11.80088 & 0.4674 & 0.4674 & 2.260 \\ 0.69863 & 0.0054157 & 0.07359 & 0.9608 & 0.9575 & 1.752 \\ 1.21638 & 0.0086884 & 0.09321 & 0.9900 & 0.9900 & 2.102 \\ 0.98524 & 0.0070880 & 0.08419 & 0.9831 & 0.9830 & 2.001 \\ 9.26014 & 0.06710 & 0.25904 & 0.9940 & 0.9939 & 1.197 \\ 0.00118 & 8.47655 \mathrm{E}-6 & 0.0029118 & 0.9982 & 0.9982 & 1.211 \\ 0.0001249 & 8.98832 \mathrm{E}-7 & 0.0009481 & 0.9999 & 0.9999 & 1.921 \\ 9231 & 66.41148 & 8.14932 & 0.9991 & 0.9991 & 1.080 \\ 0.12945 & 0.0009313 & 0.03052 & 0.8922 & 0.8914 & 2.166 \\ 0.30264 & 0.0021773 & 0.04666 & 0.8930 & 0.8922 & 2.087 \\ 0.00955 & 0.00006918 & 0.0083176 & 0.9953 & 0.9952 & 1.401 \\ 0.00713 & 0.00005165 & 0.0071870 & 0.9946 & 0.9945 & 1.419 \\ 0.00791 & 0.00005692 & 0.0075442 & 0.9912 & 0.9911 & 1.906 \\ 0.03616 & 0.0002602 & 0.01613 & 0.9631 & 0.9628 & 1.887 \\ 0.01657 & 0.0001192 & 0.01092 & 0.9894 & 0.9894 & 1.852 \\ 0.0388 & 0.0002811 & 0.01677 & 0.9481 & 0.9478 & 1.986 \\ 0.03711 & 0.0002679 & 0.01637 & 0.9604 & 0.9599 & 1.652 \\ 0.12249 & 0.0008750 & 0.02958 & 0.9176 & 0.9176 & 1.942 \\ 41995 & 299.96630 & 17.31954 & 0.9763 & 0.9763 & 1.948 \\ 963355 & 68881.1 & 82.95243 & 0.9592 & 0.9592 & 2.226 \\ 877751 & 6269.6 & 79.18111 & 0.9667 & 0.9667 & 2.177 \\ 534598 & 38818.6 & 61.79445 & 0.9664 & 0.9664 & 2.240\end{array}$


Table B2. Estimation Results for STIFS Exogenous Input Variables (Contirued)

Summary Regression Statistics

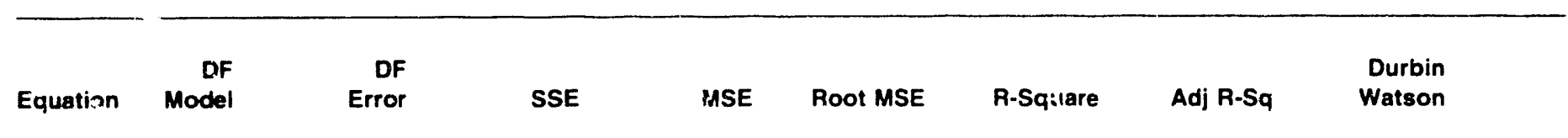

\section{Regression Group B}

Range of Fit:

ZGHDPUS 1

\section{Regression Group C}

Range of Fit:

Method of Estimation:

ELNIPUS $\quad 2$

190

\section{Regression Group D}

Range of Fit:

Method of Estimation:

ELNSPUS $\quad 1$

1

Method of Estimatio.

PAPRPAK 3

February 1979 to December 1992

Ordinary Least Squares with Autoregressive Error Correction

154

$$
0.64343
$$$$
598943
$$
0.0041781
3839.4
0.06464
61.96269

0.7551

0.9664

0.7520

0.9664

2.243

2.003

January 1977 to December 1992

Ordinary Least Squares

$\begin{array}{llllll}0.04248 & 0.0002236 & 0.01495 & 0.8163 & 0.8153 & 2.063\end{array}$

February 1981 to December 1992

Ordinary Least Squares
0.08866
0.0006288
0.02508
0.9751
0.9751
1.864

\section{Regression Group E}

Range of Fit:

Method of Estiriation:

RACPUUS 2

2

71

October 1986 to November 1992

Ordinary Least Squares with Autoregressive Error Correction

$$
3.01317
$$

0.04244

0.20601

0.9966

0.9965

1.993

\section{Regression Group F}

Range of Fit:

Method of Estimation:

September 1986 to January 1993

Ordinary Least Squares with Autoregressive Error Correction

RAIMUUS 4

73

183.32160

2.51125

1.58469

0.8064

0.7985

1.089 
Table B2. Estimation Results for STIFS Exogenous Input Variables (Continued)

\section{Parameters}

\begin{tabular}{|c|c|c|c|c|}
\hline Parameter & $\begin{array}{l}\text { Approximate } \\
\text { Estimate }\end{array}$ & $\begin{array}{c}\text { 'T' } \\
\text { Standard Error }\end{array}$ & $\begin{array}{l}\text { Approximate } \\
\text { Ratio }\end{array}$ & Prob $>|T|$ \\
\hline \multicolumn{5}{|c|}{ Regression Group A } \\
\hline $\mathrm{CICP} \_\mathrm{BO}$ & 0.00364857 & 0.0002694 & 13.54 & 0.0001 \\
\hline WPCP_BO & 0.00149972 & 0.0008052 & 1.86 & 0.0646 \\
\hline WPII_BO & 0.002 .21891 & 0.0005114 & 4.34 & 0.0001 \\
\hline PRIM_ 80 & -0.139493 & 0.07934 & -1.76 & 0.0809 \\
\hline PRIM_D1 & 0.263805 & 0.15077 & 1.75 & 0.0824 \\
\hline YD87_B0 & 5.763440 & 1.80201 & 3.20 & 0.0017 \\
\hline 187R_BO & 39.627478 & 15.63677 & 2.53 & 0.0124 \\
\hline 187R_R1 & 0.949187 & 0.02025 & 46.88 & 0.0001 \\
\hline 187R_PR & -0.373085 & 0.28142 & -1.33 & 0.1871 \\
\hline FEER_D1 & 0.00641087 & 0.0031324 & 2.05 & 0.0426 \\
\hline FEER_D2 & -0.010356 & 0.0034518 & -3.00 & 0.0032 \\
\hline GDPD_BO & 0.00315684 & 0.0001340 & 23.55 & 0.0001 \\
\hline GNPD_BO & 0.00316109 & 0.0001390 & 22.75 & 0.0001 \\
\hline GDPQ BO & 7.898661 & 1.71336 & 4.61 & 0.0001 \\
\hline GNPQ_BO & 7.499953 & 1.87646 & 4.00 & 0.0001 \\
\hline EMCM_BO & 0.128916 & 0.01840 & 7.01 & 0.0001 \\
\hline EMNF_BO & 0.123433 & 0.02902 & 4.25 & 0.0001 \\
\hline EMPI_BO & -0.00539832 & 0.0030985 & -1.74 & 0.0837 \\
\hline EMPM_BO & -0.018719 & 0.0095332 & -1.96 & 0.0516 \\
\hline HYEO_01 & -0.00182321 & 0.01604 & -0.11 & 0.9097 \\
\hline HYEO_02 & 0.045810 & 0.01574 & 2.91 & 0.0043 \\
\hline HYEO_03 & 0.055976 & 0.01490 & 3.76 & 0.0003 \\
\hline HYEO_04 & -0.00313366 & 0.01550 & -0.20 & 0.8401 \\
\hline HYEO_05 & 0.017655 & 0.01519 & 1.16 & 0.2474 \\
\hline HYEO_06 & -0.065572 & 0.01462 & -4.49 & 0.0001 \\
\hline HYEO_07 & -0.099891 & 0.01522 & -6.56 & 0.0001 \\
\hline HYEO 08 & -0.052329 & 0.01492 & -3.51 & 0.0006 \\
\hline HYEO_09 & -0.015396 & 0.01390 & -1.11 & 0.2699 \\
\hline HYEO_10 & 0.013350 & 0.01504 & 0.89 & 0.3763 \\
\hline HYEO_11 & 0.061609 & 0.01520 & 4.05 & 0.0001 \\
\hline NUEO_BO & 0.134932 & 0.01800 & 7.50 & 0.0001 \\
\hline NUEO_01 & -0.047533 & 0.02457 & -1.93 & 0.0552 \\
\hline NUEO_02 & -0.178705 & 0.02460 & -7.26 & 0.0001 \\
\hline NUEO_03 & -0.263818 & 0.02458 & -10.73 & 0.0001 \\
\hline NUEO_04 & -0.236274 & 0.02457 & -9.61 & 0.0001 \\
\hline NUEO_05 & -0.093384 & 0.02458 & -3.80 & 0.0002 \\
\hline NUEO_06 & 0.010057 & 0.02459 & 0.41 & 0.6832 \\
\hline NUEO_07 & -0.022473 & 0.02459 & -0.91 & 0.3625 \\
\hline NUEO_. 08 & -0.098279 & 0.02460 & -4.00 & 0.0001 \\
\hline NUEO_09 & -0.216460 & 0.02452 & -8.83 & 0.0001 \\
\hline NUEO__10 & -0.271445 & 0.02504 & -10.84 & 0.0001 \\
\hline NUEO_ 11 & -0.098591 & 0.02508 & -3.93 & 0.0001 \\
\hline KQHM_BO & 0.118546 & 0.0089203 & 13.29 & 0.0001 \\
\hline $\mathrm{KOH} 1 \_\mathrm{HM}$ & 0.629067 & 0.0055515 & 113.32 & 0.0001 \\
\hline ORCA_D2 & -0.073252 & 0.01316 & -5.57 & 0.0001 \\
\hline PA48_BO & -0.011581 & 0.0047558 & -2.44 & 0.0162 \\
\hline
\end{tabular}


Table B2. Estimation Results for STIFS Exogenous Input Variables (Continued)

Parameters

\begin{tabular}{|c|c|c|c|c|}
\hline Parameter & $\begin{array}{l}\text { Approximate } \\
\text { Estimate }\end{array}$ & $\begin{array}{c}\text { 'T' } \\
\text { Standard Error }\end{array}$ & $\begin{array}{c}\text { Approximate } \\
\text { Ratio }\end{array}$ & Prob $>|T|$ \\
\hline \multicolumn{5}{|c|}{ Regression Group A (Continued) } \\
\hline ZOCB_D1 & 0.00582117 & 0.0031867 & 1.83 & 0.0699 \\
\hline ZOIS_BO & -0.00373843 & 0.0034677 & -1.08 & 0.2829 \\
\hline ZOMN__20 & 0.980285 & 0.04279 & 22.91 & 0.0001 \\
\hline ZOMN_28 & 0.011822 & 0.0081478 & 1.45 & 0.1491 \\
\hline ZOTO_20 & 0.755739 & 0.04050 & 18.66 & 0.0001 \\
\hline ZOTO_28 & 0.00800563 & 0.0083953 & 0.95 & 0.3420 \\
\hline ZO20_BO & 0.00212375 & 0.0003004 & 7.07 & 0.0001 \\
\hline ZO26_BO & 0.00171969 & 0.0008200 & 2.10 & 0.0378 \\
\hline ZO28_BO & 0.00160696 & 0.0006494 & 2.47 & 0.0145 \\
\hline 2029_BO & -0.139077 & 0.02124 & -6.55 & 0.0001 \\
\hline ZO29_PA & 0.00977621 & 0.0014716 & 6.64 & 0.0001 \\
\hline 2032_KQ & 0.027977 & 0.01643 & 1.70 & 0.0908 \\
\hline ZO33_BO & -0.00193734 & 0.0022 .444 & -0.86 & 0.3895 \\
\hline PAP48_L1 & -0.352904 & 0.05945 & -5.94 & 0.0001 \\
\hline HDPUS_L1 & 0.112312 & 0.04196 & 2.68 & 0.0083 \\
\hline HDPMA_L1 & 0.129936 & 0.04012 & 3.24 & 0.0015 \\
\hline HDPNE_L1 & 0.040602 & 0.04375 & 0.93 & 0.3550 \\
\hline HYEOP_L1 & -0.062829 & 0.07626 & -0.82 & 0.4116 \\
\hline HYEOP_L2 & -0.216183 & 0.07512 & -2.88 & 0.0047 \\
\hline HYEOP_L3 & -0.277122 & 0.07542 & -3.67 & 0.0004 \\
\hline CICPI_L1 & 0.279614 & 0.05688 & 4.92 & 0.0001 \\
\hline EMCMP_L1 & 0.823219 & 0.01749 & 47.06 & 0.0001 \\
\hline EMNFP_L1 & 0.833816 & 0.01563 & 53.34 & 0.0001 \\
\hline EMPIP_L1 & 0.735422 & 0.03604 & 20.40 & 0.0001 \\
\hline EMPMP_L1 & 0.805415 & 0.02011 & 40.05 & 0.0001 \\
\hline FEERI_L1 & 0.647201 & 0.05231 & 12.37 & 0.0001 \\
\hline GDPDI_L1 & 0.443392 & 0.04256 & 10.42 & 0.0001 \\
\hline GDPQX_LL1 & 0.653043 & 0.02797 & 23.35 & 0.0001 \\
\hline GNPDI_L1 & 0.464808 & 0.04213 & 11.03 & 0.0001 \\
\hline GNPQX_L1 & 0.672259 & 0.02929 & 22.95 & 0.0001 \\
\hline I87RX_L1 & 0.795424 & 0.04744 & 16.77 & 0.0001 \\
\hline KQHMP_L1 & 0.864453 & 0.02553 & 33.86 & 0.0001 \\
\hline KRDRX_L1 & -0.554582 & 0.05178 & -10.71 & 0.0001 \\
\hline PRIME L1 & 0.742128 & 0.03818 & 19.44 & 0.0001 \\
\hline WPCPI_L.1 & 0.717631 & 0.03747 & 19.15 & 0.0001 \\
\hline WPIIN_L1 & 0.851139 & 0.03306 & 25.75 & 0.0001 \\
\hline YD870_L1 & 0.640491 & 0.05194 & 12.33 & 0.0001 \\
\hline ZOCBI_L1 & -0.136207 & 0.06857 & -1.99 & 0.0490 \\
\hline ZOISI_L1 & -0.047958 & 0.01844 & -2.60 & 0.0103 \\
\hline ZOMNI_L1 & -0.125351 & 0.03720 & -3.37 & 0.0010 \\
\hline ZOTOI_L1 & -0.049103 & 0.03911 & -1.26 & 0.2114 \\
\hline ZO201_L1 & -0.361526 & 0.04647 & -7.78 & 0.0001 \\
\hline ZO26I_L1 & -0.545527 & 0.05988 & -9.11 & 0.0001 \\
\hline ZO28I_L1 & -0.194994 & 0.05780 & -3.37 & 0.0010 \\
\hline ZO29I_L1 & -0.133332 & 0.06913 & -1.93 & 0.0558 \\
\hline ZO32I_L1 & -0.326647 & 0.05943 & -5.50 & 0.0001 \\
\hline ZVVICDF_Li & 0.221356 & 0.06172 & 3.59 & 0.0005 \\
\hline
\end{tabular}


Table B2. Estimation Results for STIFS Exogenous Input Variables (Continued)

\section{Parameters}

\begin{tabular}{|c|c|c|c|c|}
\hline Parameter & $\begin{array}{l}\text { Approximate } \\
\text { Estimate }\end{array}$ & $\begin{array}{c}\text { 'T' } \\
\text { Standard Error }\end{array}$ & $\begin{array}{c}\text { Approximate } \\
\text { Ratio }\end{array}$ & Prob $>$ IT \\
\hline \multicolumn{5}{|c|}{ Regression Group B } \\
\hline PAPR_BO & 0.00763643 & 0.0048182 & 1.58 & 0.1150 \\
\hline PAPR_D1 & -0.017206 & 0.0079478 & -2.16 & 0.0319 \\
\hline PAPAK_L1 & -0.350387 & 0.07553 & -4.64 & 0.0001 \\
\hline ZGHDP_L1 & 0.080930 & 0.07992 & 1.01 & 0.3128 \\
\hline
\end{tabular}

Regression Group C

ELNI BO

ELNI_D1

Regression Group D

ELNS_BO

0.00343410

Regression Group E

RACP_IM

RACPU_L1

1.004174

0.667117

0.0037165

0.08905
0.0021043

1.63

0.1049

0.58

0.5657

0.0027949

$-1.35$

0.1793

(1.63
RACPU_L1

\section{Regression Group F}

RAIM_0

RAIM_T

AAIM_D

RAIMU_L1

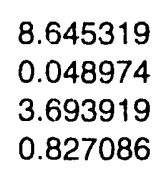

7.08212

0.03923

1.30165

0.07379
1.22
1.25
2.84
11.21

0.2261

0.2158

0.0059

0.0001 
I

\section{$\nabla$}
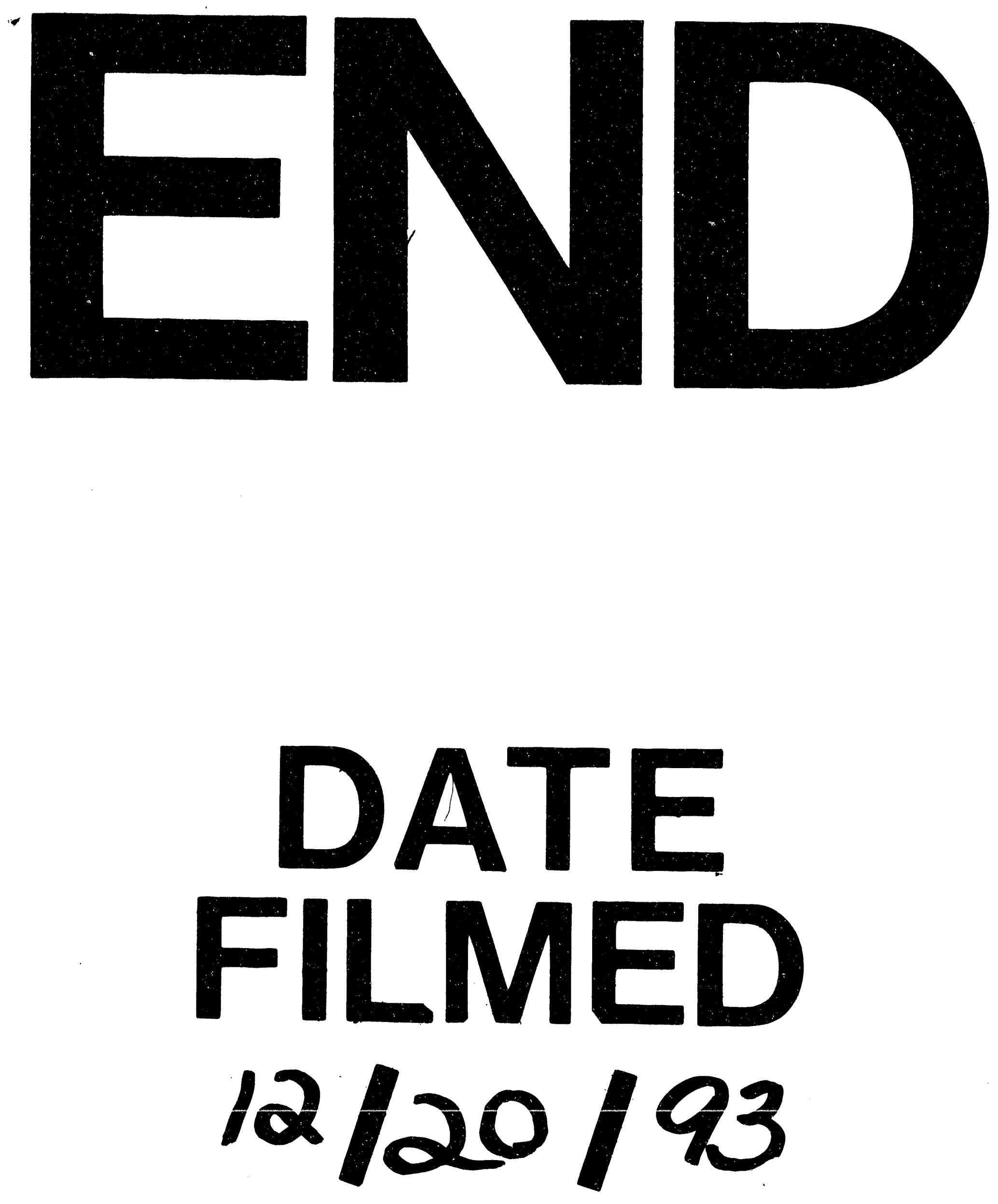
